\title{
Archaeological Studies of the Hatchel Site (41BW3) on the Red River in Bowie County, Texas
}

Timothy K. Perttula

Heritage Research Center, Stephen F. Austin State University

Follow this and additional works at: https://scholarworks.sfasu.edu/ita

Part of the American Material Culture Commons, Archaeological Anthropology Commons, Environmental Studies Commons, Other American Studies Commons, Other Arts and Humanities Commons, Other History of Art, Architecture, and Archaeology Commons, and the United States History Commons

Tell us how this article helped you.

This Article is brought to you for free and open access by the Center for Regional Heritage Research at SFA ScholarWorks. It has been accepted for inclusion in Index of Texas Archaeology: Open Access Gray Literature from the Lone Star State by an authorized editor of SFA ScholarWorks. For more information, please contact cdsscholarworks@sfasu.edu. 


\section{Archaeological Studies of the Hatchel Site (41BW3) on the Red River in Bowie County, Texas}

\section{Creative Commons License}

\section{(c) (1) (8)}

This work is licensed under a Creative Commons Attribution-NonCommercial 4.0 International License 


\section{Archaeological Studies of the Hatchel Site (41BW3) on the Red River in Bowie County, Texas}

\section{Timothy K. Perttula}

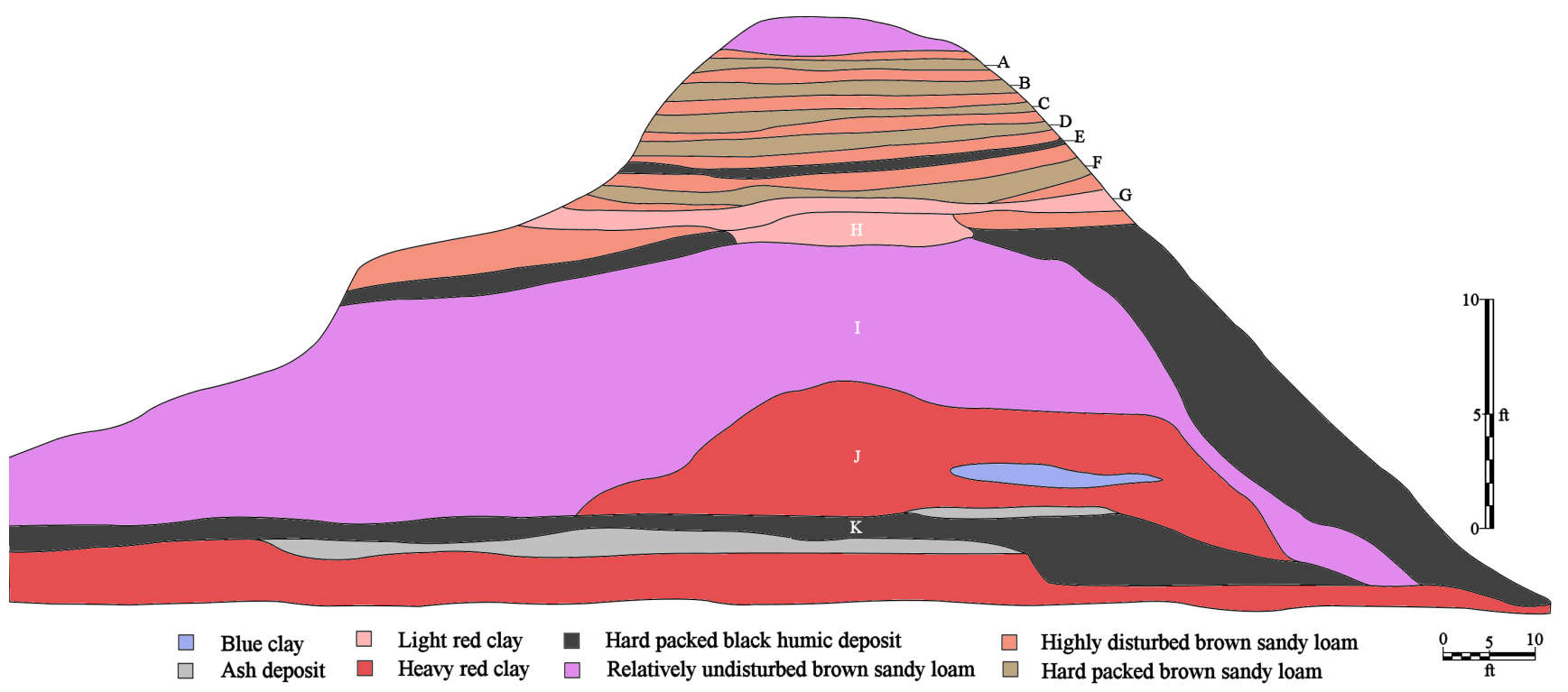

Special Publication No. 23

Friends of Northeast Texas Archaeology, Austin and Pittsburg 


\title{
Editor, Timothy K. Perttula 10101 Woodhaven Dr. Austin, Texas 78753 tkp4747@aol.com
}

\section{Distribution, Bo Nelson, 344 CR 4154 \\ Pittsburg, Texas 75686 \\ RBoNelson@aol.com}

\begin{abstract}
Cover art:
Schematic profile originally prepared by WPA archaeologists of the platform mound at the Hatchel site (Figure prepared by Lance Trask)
\end{abstract}

Copyright (C) 2014, Friends of Northeast Texas Archaeology (Pittsburg and Austin) 


\section{Table of Contents}

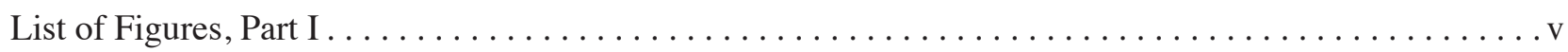

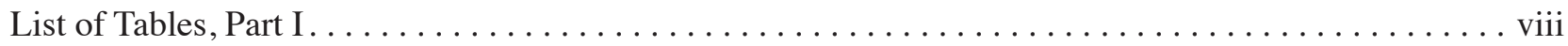

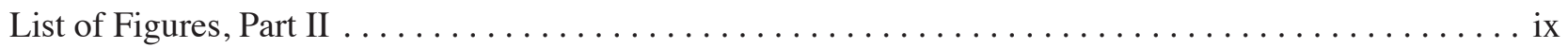

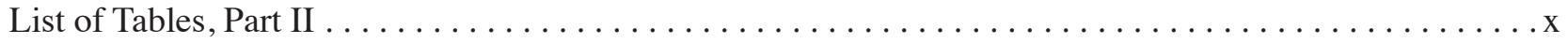

Part I: The Architecture of Caddo Temple Structures on the Platform Mound at the Hatchel Site on the Red River in Northeast Texas . . . . . . . . . . . . . . . . . . . . . . . . 1

Timothy K. Perttula

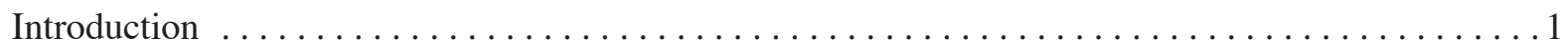

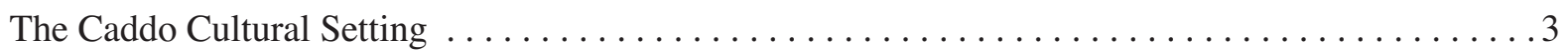

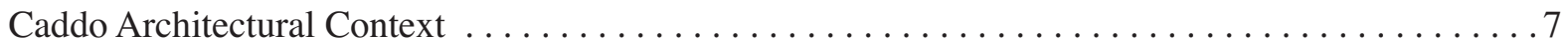

WPA Archaeological Investigations in the Platform Mound $\ldots \ldots \ldots \ldots \ldots \ldots \ldots \ldots \ldots \ldots$

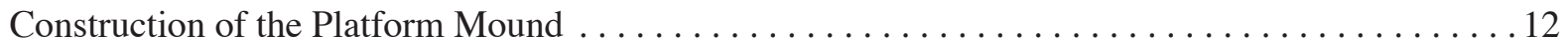

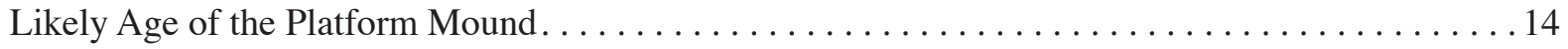

Temple Structures on the Mound .................................... 14

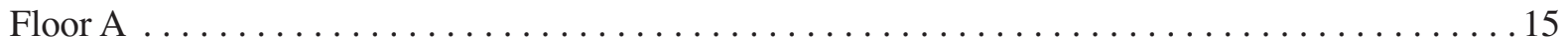

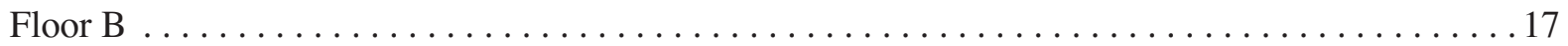

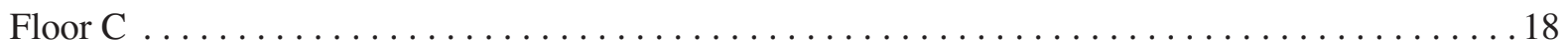

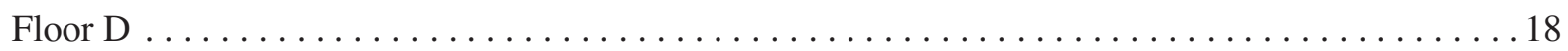

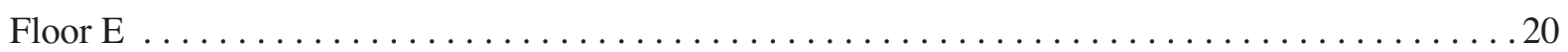

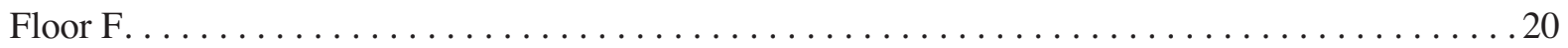

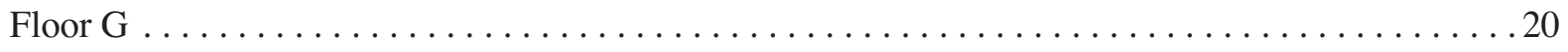

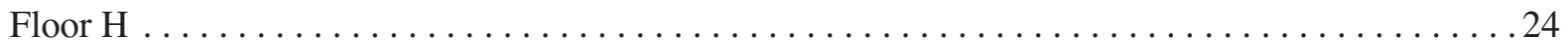

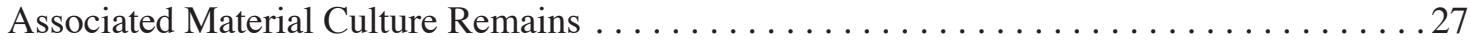

Burials in Zones $\mathrm{E}, \mathrm{F}$, and $\mathrm{H}$

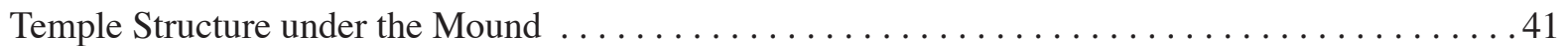

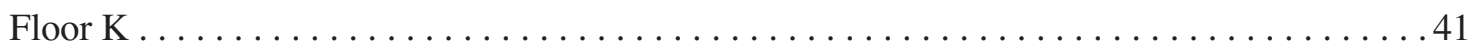

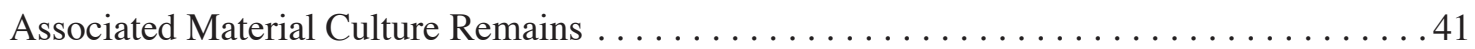

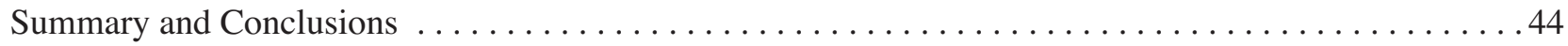

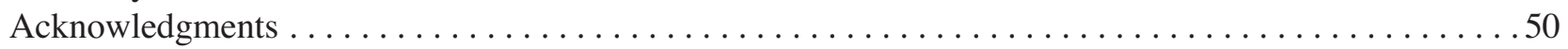

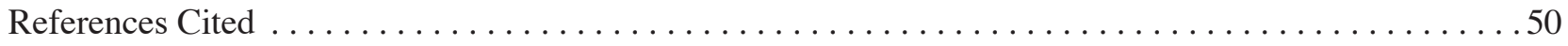

Part II : Detailed Analysis of the Ceramic Sherds from Village Plot 1 Excavations

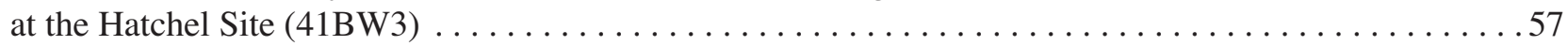

Timothy K. Perttula

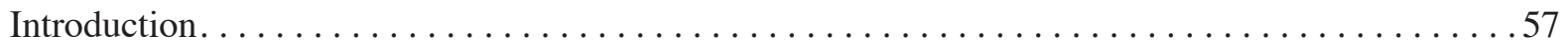

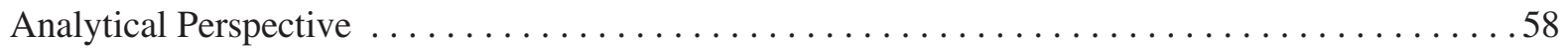

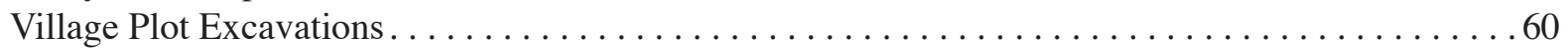

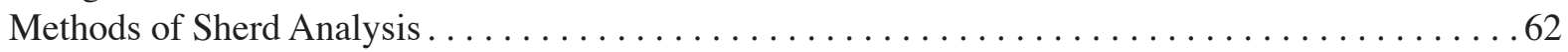

Plain Sherds . . . . . . . . . . . . . . . . . . . . . . . . . . . . 65

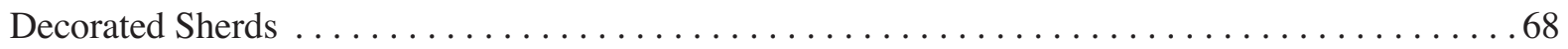

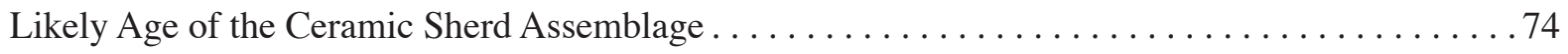

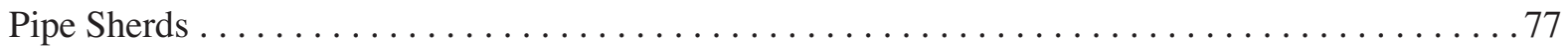


Archaeological Studies of the Hatchel Site (41BW3) on the Red River in Bowie County, Texas

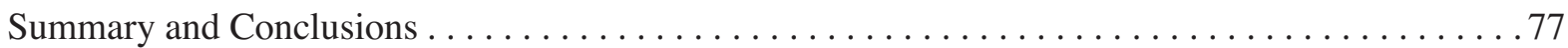

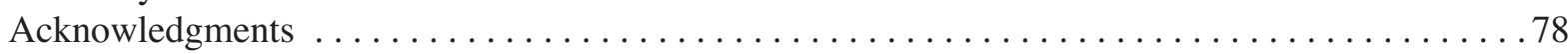

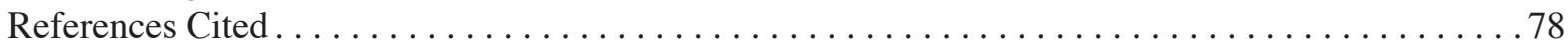

Appendix 1, Detailed analysis of sherds from the Village Plot 1 area at the Hatchel site...........81 


\section{List of Figures, Part I}

1. The mounds and village area at the Hatchel site: a, overview; b, platform mound,

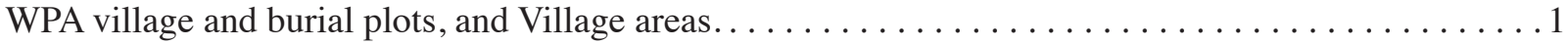

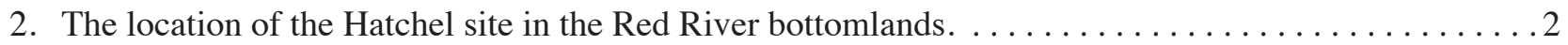

3. The Hatchel site and other Nasoni Caddo sites on the Red River in Bowie County, Texas... . . . . . . 3

4. The platform mound at the Hatchel site: a, WPA map showing the Hatchel mound, Burial Plots 1-4, and 1938-1939 farm structures; b, looking south at the Hatchel platform mound from the edge of the Red River floodplain. Image 41BW3-9, Texas Archeological Research Laboratory, The University of Texas at Austin. . . . . . . . . . . . . . . . . 4

5. The remnant of the platform mound at the Hatchel site in 2003 , with a barn standing on it. . . . . ...5

6. The southern and northern Caddo areas at their maximum extent ca. A.D. 1000 or

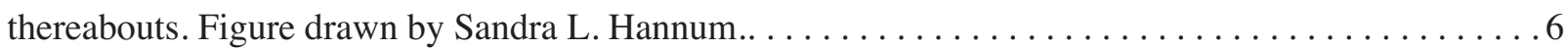

7. Looking north at village areas at the Hatchel site, with the platform mound in the distance, behind the barn. Image 41BW3-125, Texas Archeological Research Laboratory, The University of Texas at Austin. . . . . . . . . . . . . . . . .

8. Looking at the western end of the platform mound before excavations were commenced. Image 41BW3-7, Texas Archeological Research Laboratory, The University of Texas at Austin. . . . . 8

9. WPA crew excavating the uppermost deposits in the platform mound. Image 41BW3-121, Texas Archeological Research Laboratory, The University of Texas at Austin. . . . . . . . . . . . 9

10. WPA crew excavating down through the mound, standing on Zone H. Image 41BW3-202, Texas Archeological Research Laboratory, The University of Texas at Austin. . . . . . . . . . 10

11. Length-wise cross-section of the platform mound from Zone H. Image 41BW3-219, Texas Archeological Research Laboratory, The University of Texas at Austin. . . . . . . . . . . . 10

12. Profile of the platform mound, with the man standing on Zone H. Image 41BW3-207. Texas Archeological Research Laboratory, The University of Texas at Austin. . . . . . . . . . . . 11

13. WPA trenches to reach the pre-mound surface. Image courtesy of the Texas Archeological Research Laboratory, The University of Texas at Austin.

14. Cross-section of Zones A-K in the platform mound excavations at the Hatchel site: a, as originally drawn by WPA archaeologists; b, redrawn to more clearly depict the

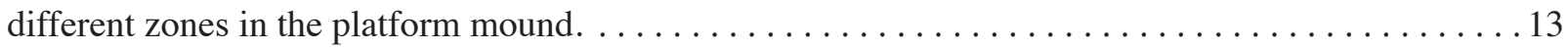

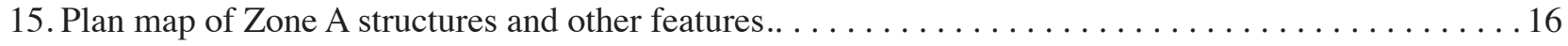

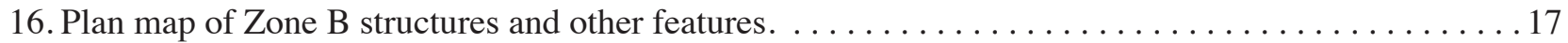

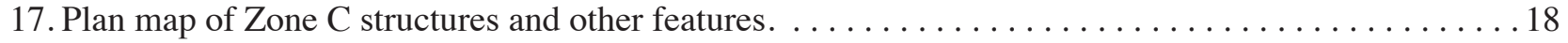

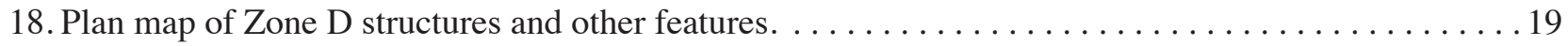

19. Plan map of Zone E structures and other features.. $\ldots \ldots \ldots \ldots \ldots \ldots \ldots \ldots \ldots \ldots \ldots \ldots \ldots \ldots \ldots \ldots \ldots$

20. Plan map of Zone F structures and other features.. $\ldots \ldots \ldots \ldots \ldots \ldots \ldots \ldots \ldots \ldots \ldots \ldots \ldots \ldots \ldots \ldots \ldots \ldots \ldots$

21. Southern portion of Feature 15 and its extended entranceway. Image 41BW3-128, Texas Archeological Research Laboratory, The University of Texas. . . . . . . . . . . . . 23 


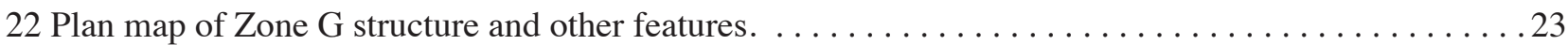

23. Northern half of Feature 22. Image 41BW3-236, Texas Archeological Research Laboratory,

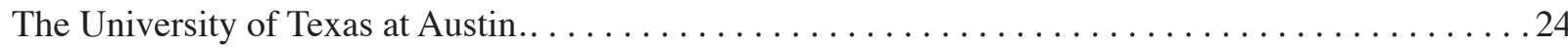

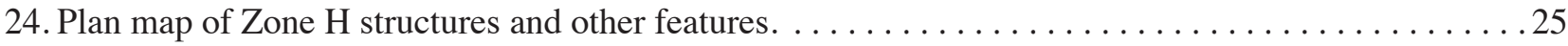

25. Looking west at Features 16 and 17 in Zone H. Image 41BW3-163, Texas Archeological

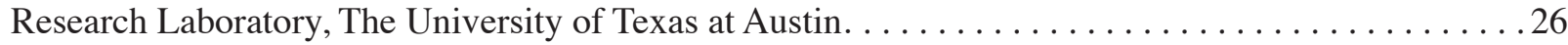

26. Black Avery Engraved flaring rim bowl from Feature 12 in Zone D: a, photo; b, redrawn from Laughlin (1940). Photograph courtesy of TARL . . . . . . . . . . . . . . . . . . . 27

27. Vessels from Zone F, G, and H: a-b, plain carinated bowl; c-d, Simms Engraved carinated bowl; e-f, Karnack Brushed-Incised jar; g, incised jar; h, lip notched bowl; i, Barkman Engraved carinated bowl; b, d, and f redrawn from Laughlin (1940). Photographs courtesy of TARL... . . . . . 28

28. Ceramic duck effigy head sherd from Zone B in the platform mound at the Hatchel site.

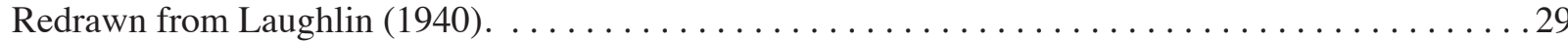

29. Clay elbow pipes in the platform mound at the Hatchel site: a-d, Zone H; e, Zone I.

Redrawn from Laughlin (1940) . . . . . . . . . . . . . . . . . . . . . . . . . . . . . . . . 30

30. Stemmed arrow points from the platform mound at the Hatchel site: a, Zone F; b-f,

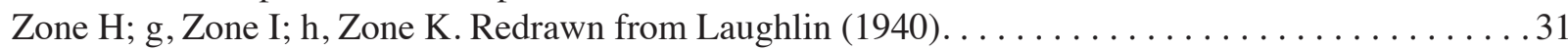

31. Maud arrow points from the platform mound at the Hatchel site: a-b, Zone B; c-d, Zone C; e, Zone D; f-h, Zone E; i, Zone F; j-k, Zone H. Redrawn from Laughlin (1940). . . . . . . . . 32

32. Celts from the platform mound at the Hatchel site: a, Zone D; b, Zone F; c, Zone G;

d, Zone H; e-f, Zone I. Redrawn from Laughlin $(1940) \ldots \ldots \ldots \ldots \ldots \ldots \ldots \ldots \ldots \ldots \ldots$

33. Celts from the lower mound zones and Zone K under the mound: a, Zone H; b,

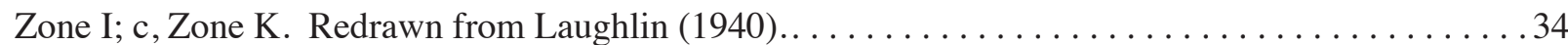

34. Quartz crystals from the platform mound at the Hatchel site: a, Zone F; b, Zone H.

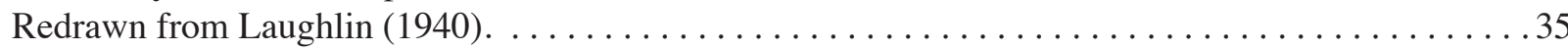

35. Perforated copper strips from Zone $\mathrm{H}$ in the platform mound at the Hatchel site.

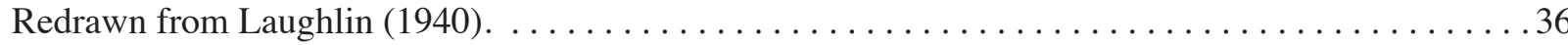

36. Bone and teeth artifacts from the platform mound at the Hatchel site. Redrawn from Laughlin (1940): a, bone hairpin from Zone C; b, bone hair ornament from Zone H; c, canine tooth pendant from Zone G; d, bone ear spool from Zone G; e, canine tooth pendant from Zone F; f-g, canine tooth pendants from Zone $\mathrm{H}$; h, bear tooth from Zone $\mathrm{H}$;

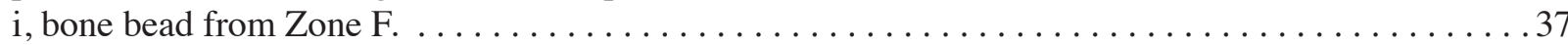

37. Vessels from Zone E, including Burial 1: a, d, Keno Trailed bowl; b, e, Simms Engraved carinated bowl; c, f, Foster Trailed-Incised, var. unspecified jar.

Redrawn from Laughlin (1940). Photographs courtesy of TARL. . . . . . . . . . . . . . . . . 38

38. Vessels from Burial 2 in Zone F: a-b, Barkman Engraved carinated bowl; c-d, Foster Trailed-Incised, var. unspecified jar; e-f, Foster Trailed-Incised, var. Red Lake jar. Redrawn from Laughlin (1940). Photographs courtesy of TARL. . . . . . . . . . . . . . . . . . . . 39

39. Vessels from Burial 3 in Zone H: a, d, Avery Engraved, var. Bradshaw compound bowl; b, e, McKinney Plain jar; c, f appliqued rattle bowl with broken pedestal legs. Redrawn from Laughlin (1940). Photographs courtesy of TARL. 
40. Vessels from Burial 4 in the platform mound at the Hatchel site: a, d, Hodges Engraved, var. Candler bottle; b, e, engraved bowl; c, f, plain bowl. Redrawn from

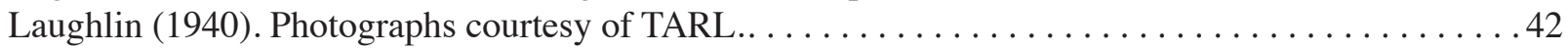

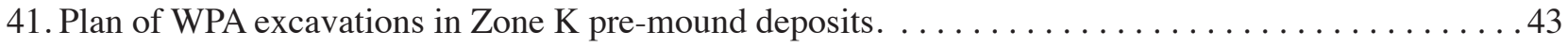

42. Feature 25 and its interior partition, in Zone $\mathrm{K}$ under the platform mound, at the Hatchel site. Image 41BW3-265, Texas Archeological Research Laboratory,

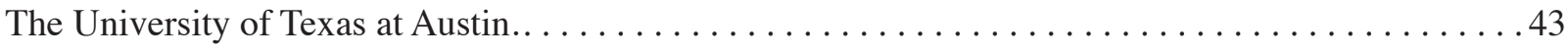

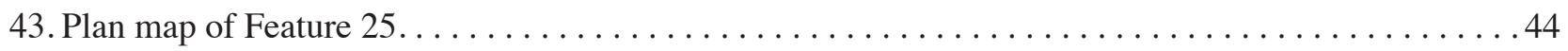

44. Crockett Curvilinear Incised carinated bowl from Zone K: a, photograph; b,

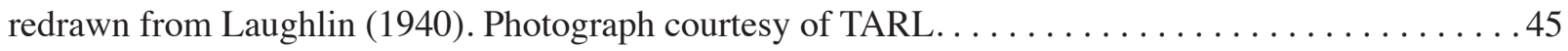




\section{List of Tables, Part I}

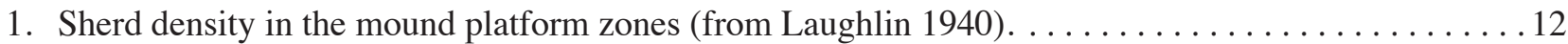

2. Characteristics of the clearly defined structures on the platform mound at the Hatchel

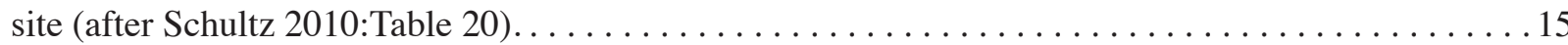




\section{List of Figures, Part II}

1. Nasoni Caddo compound as shown on the 1691 Teran map of the Nasoni Caddo village. (Redrawn from the original in the J. P. Bryan Map Collection, CT0108, Center for American

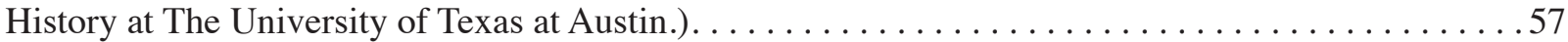

2. The Hatchel site and other contemporaneous Late Caddo, Texarkana phases sites along the Red River.. . . . . . . . . . . . . . . . . . . . . . . . . . . . . . . . 58

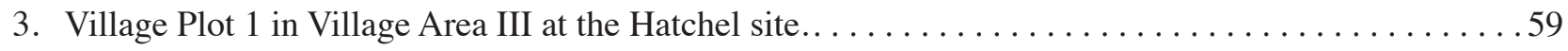

4. Village Plot 1 WPA excavations. Note Fea. 2 in left center of photograph. Image 41BW3-77, Texas Archeological Research Laboratory, The University of Texas at Austin. . . . . . . 60

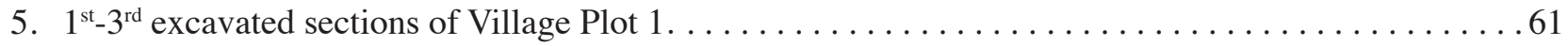

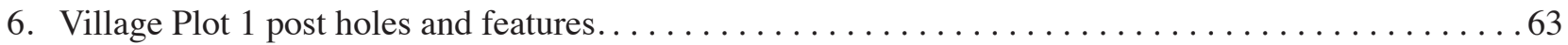

7. Rim and body wall thickness in the plain, utility, and fine ware sherds in Village Plot 1 at the Hatchel site. . . . . . . . . . . . . . . . . . . . . . . . . . . . . . . . . . . . . . . . 69

8. Selected decorative elements on utility ware sherds from Village Plot 1: a, c-d, f, Foster Trailed-Incised; b, cf. Pease Brushed-Incised; e, possible Sanson Incised.. . . . . . . . . . . . . . . 71

9. Engraved, engraved-punctated, and trailed decorative elements on Village Plot 1 fine ware sherds: a, f-g, m, engraved-punctated; b-c, trailed; d-e, h-1, n-p, engraved. . . . . . . . . . .73

10. Decorative elements on selected fine ware and utility ware sherds from Village Plot 2

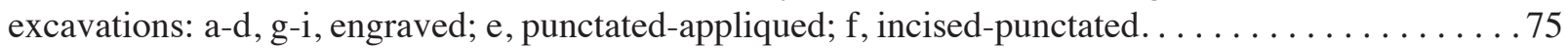

11. Decorative elements on selected fine ware and utility ware sherds from the Burial Plot excavations at the Hatchel site: e, incised-appliqued; b, k, incised-punctated; c-d, f-g, i, m, engraved; e, incised; h, j, l, engraved-punctated. . 


\section{List of Tables, Part II}

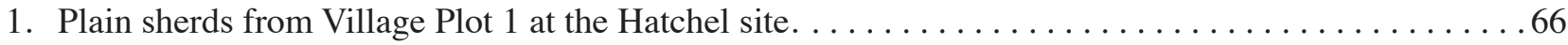

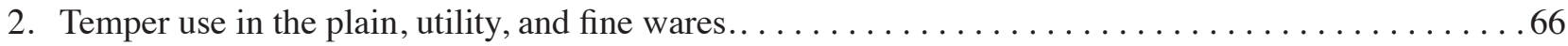

3. Firing conditions in the plain, utility, and fine wares in Village Plot 1 at the Hatchel site.........68

4. Surface treatment of plain, utility, and fine ware sherds in Village Plot $1 \ldots \ldots \ldots \ldots \ldots$

5. Methods of decoration of sherds in Village Plot 1 at the Hatchel site . . . . . . . . . . . . . . 69

6. Significant decorative elements in the Village Plot 1 utility wares... . . . . . . . . . . . 70

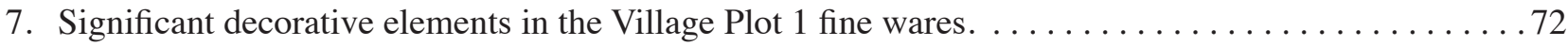




\section{Part I}

\section{The Architecture of Caddo Temple Structures on the Platform Mound at the Hatchel Site on the Red River in Northeast Texas}

\section{Timothy K. Perttula}

Introduction

The Hatchel site (41BW3) is a major prehistoric and protohistoric Caddo village and mound center on a natural levee deposit in the floodplain of the Red River in Bowie County, Texas. The platform mound and the main part of the associated village overlooks two channel lakes of the river; these likely were part of the channel of the river when the site was occupied by the Caddo (Figures 1 and 2).
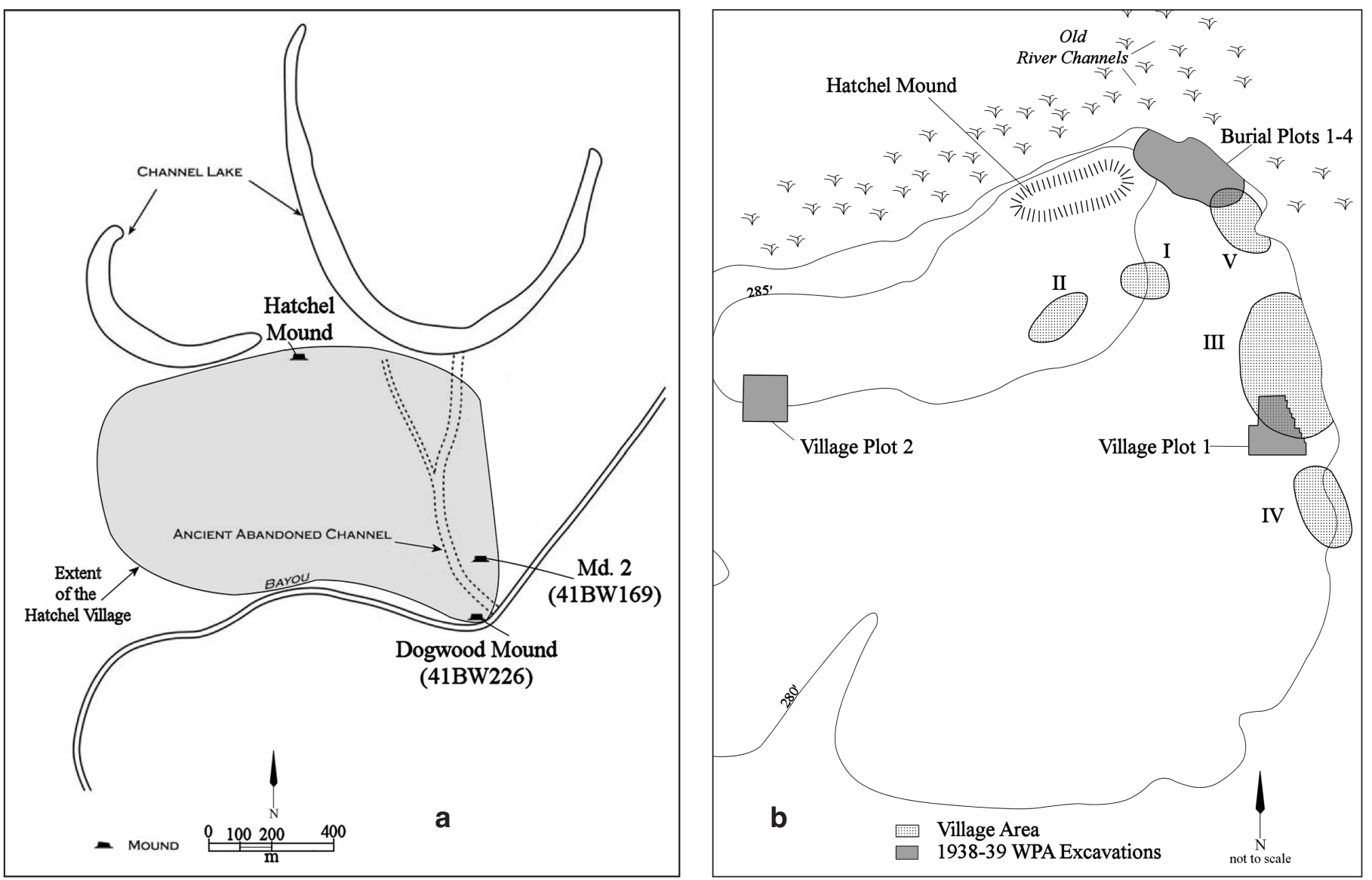

Figure 1. The mounds and village area at the Hatchel site: a, overview; b, platform mound, WPA village and burial plots, and Village areas.

The site was occupied by the Caddo from at least A.D. 1040 to the late $17^{\text {th }}$ century. The earliest end of this age range is based on 2-sigma calibrated ages from radiocarbon dates obtained in the site's village areas (Perttula and Nelson 2003; Perttula 2005). 


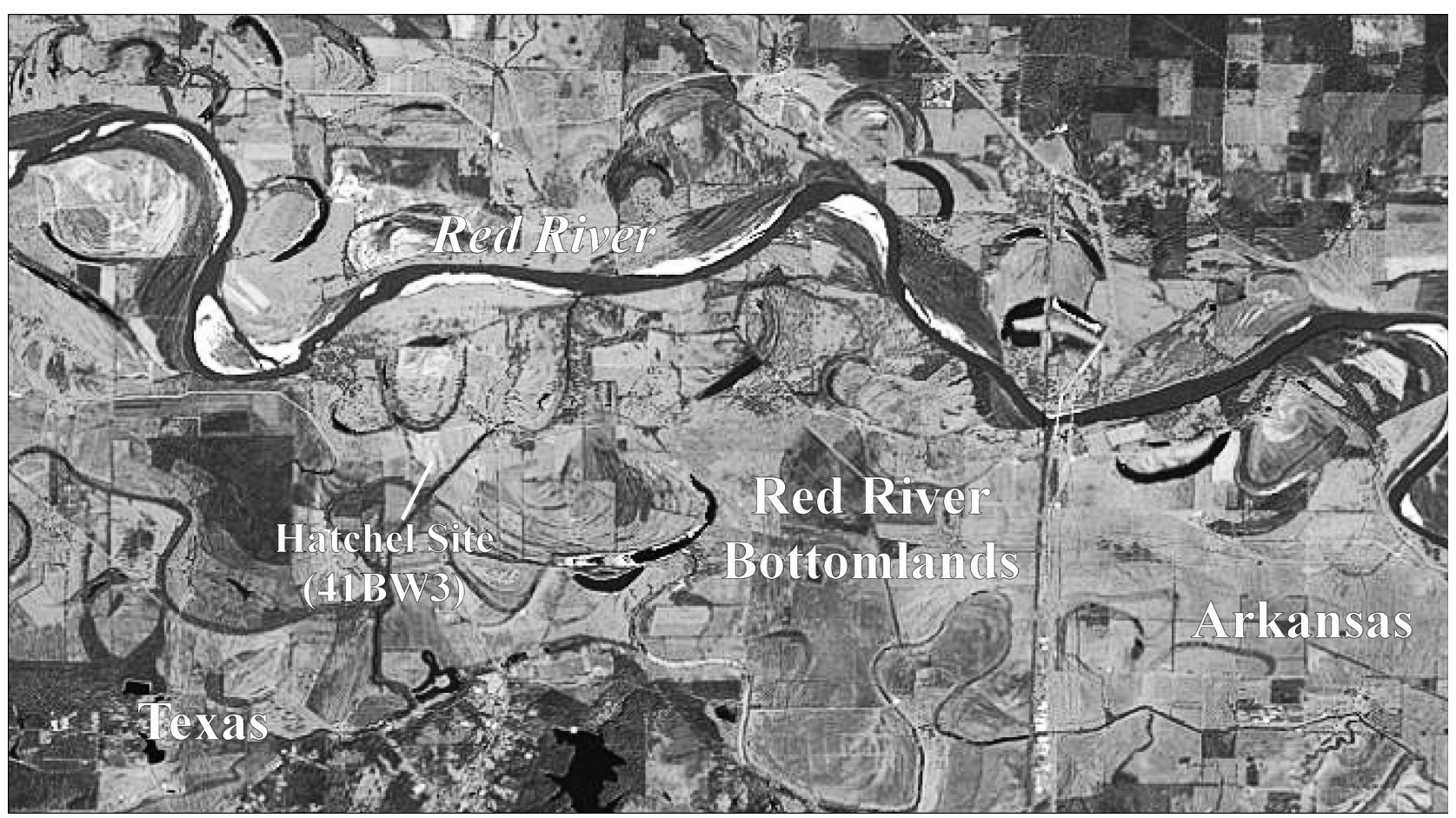

Figure 2. The location of the Hatchel site in the Red River bottomlands.

In 1691, a Spanish expedition led by Don Domingo Teran de los Rios explored the Red River area (Hatcher 1999), and a detailed map was drawn of a Nasoni Caddo village that depicted a templo or temple mound at the western end of the village. That mound has been identified as the large earthen mound at the Hatchel site (see Wedel 1978). The map also showed many houses, and associated outbuildings, from numerous individual compounds in the village. The village itself is believed to have extended several miles along the Red River, likely encompassing contemporaneous sites such as Eli Moores (41BW2), Paul Mitchell (41BW4), Hargrove Moores (41BW39), and Horace Cabe (41BW14) (Figure 3). The Roseborough Lake site (41BW5) is a later Nasoni Caddo settlement that postdates the community shown on the Teran map by a generation or more (Gilmore 1986).

It is known that the Hatchel site contains extensive village archaeological deposits to the south, southeast, and southwest of the main earthen mound (see Perttula and Nelson 2003; Perttula 2005), as well as village cemetery areas in Burial Plots 1-4 (Figure 4a). The platform mound stood at least $25 \mathrm{ft}$. in height at the time of the Works Progress Administration (WPA) work investigations (Figure 4b). A second, and lower mound (Md. 2), stood about $3000 \mathrm{ft}$. southeast of the Hatchel Mound, in a cultivated field some distance east of one of the village areas, in what is considered the Hill Farm site (41BW169, Perttula et al. 2008).

The WPA excavations at the Hatchel site have not been fully studied or the results fully published to date, more than 70 years after the excavations were completed. The article represents a renewed examination of the records and collections from the WPA archaeological investigations in the platform mound, and the findings concerning the construction and use of the mound contributes to a fuller understanding of the history and prehistory of the Caddo peoples that lived at the Hatchel site and other villages in the Red River valley of Northeast Texas. Only a small remnant of the platform mound remains at the Hatchel site (Figure 5). 


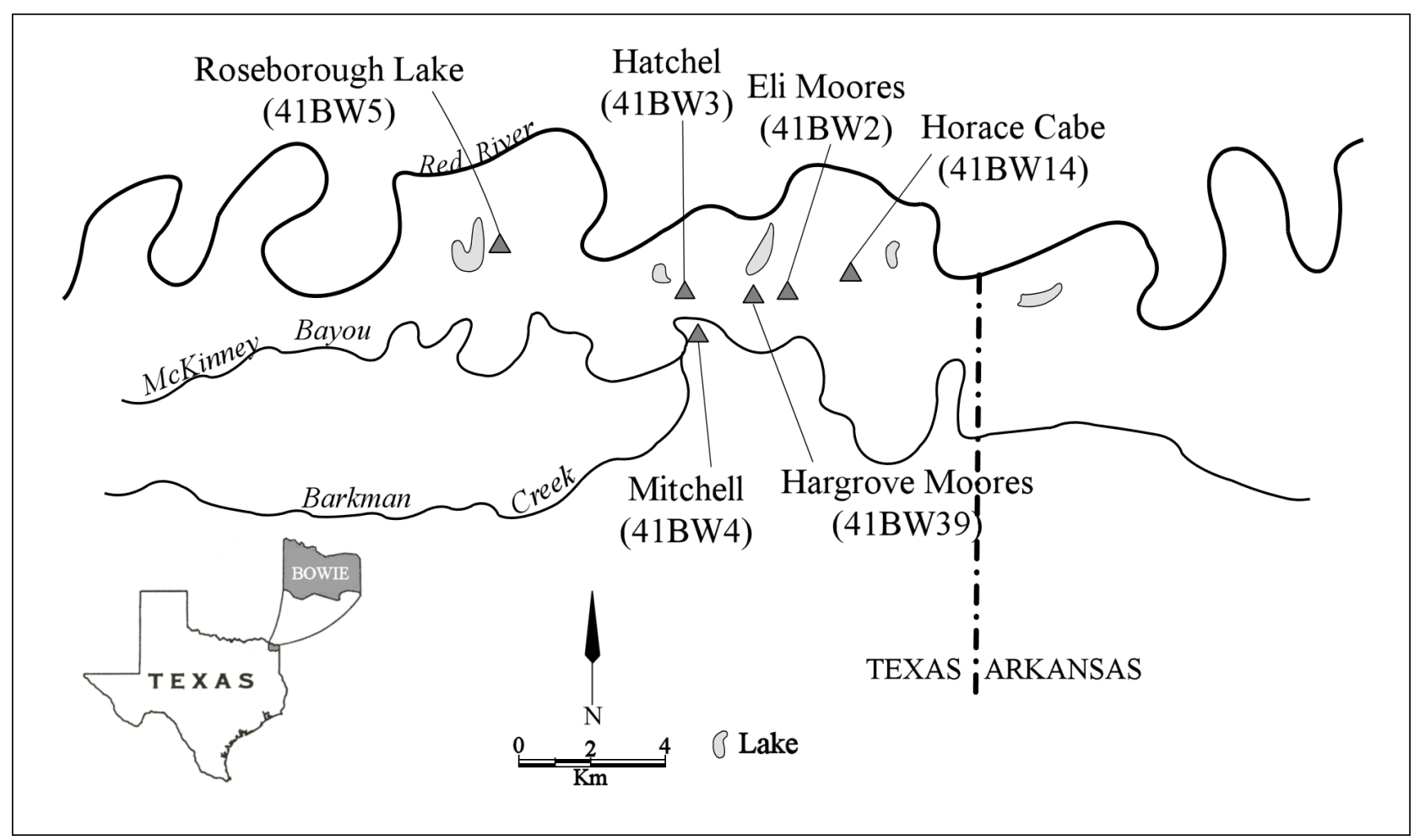

Figure 3. The Hatchel site and other Nasoni Caddo sites on the Red River in Bowie County, Texas.

\section{The Caddo Cultural Setting}

In ancestral times, beginning in the $9^{\text {th }}$ and $10^{\text {th }}$ centuries A.D., long before Europeans came to what became Texas and the United States, the Caddo Indians had become mound builders, expert traders and artisans, and eventually accomplished farmers, as well as the most socially complex Native American communities living between the Mississippi River and the ancestral Puebloan peoples of the American Southwest. When Europeans came among the Caddo in the late $17^{\text {th }}$ century, they relied on the good will of the Caddo to explore what became Texas, as well as the diplomatic and economic skills of the people. Following disease, depredations, and territorial dispossession at the hands of French, Spanish, English, and American speculators, mercenaries, priests, traders, and land developers, by 1835, the Caddo's fate in Texas became clear, and the policies of the Republic of Texas and the United States between them led to their forced exodus from Texas to Indian Territory in 1859. The Caddo, now the Caddo Nation of Oklahoma, live to this day in their new western Oklahoma home.

During the more than 2400 years that the Caddo peoples, and their Woodland period (ca. 500 B.C. to A.D. 800/850) ancestors, lived in Texas, they inhabited camp sites, hamlets, villages, and civic-ceremonial mound centers over a large area of four different states, including eastern Texas, northwestern Louisiana, southwestern Arkansas, and eastern Oklahoma, centered on the Red River and its tributary streams. More specifically, the southern Caddo area (Figure 6) is centered on the Red River and its main tributary streams, as well as the Sabine and Neches rivers in East Texas, and includes the Gulf Coastal Plain and Ouachita Mountains physiographic provinces. The northern Caddo area is centered in the Arkansas River basin in the states of Arkansas and Oklahoma, and includes parts of the adjoining Ozark Plateau. At its maximum extent, the Caddo archaeological area extends $600 \mathrm{~km}$ north to south and $300 \mathrm{~km}$ east to west, covering approximately $180,000 \mathrm{~km}^{2}$. 

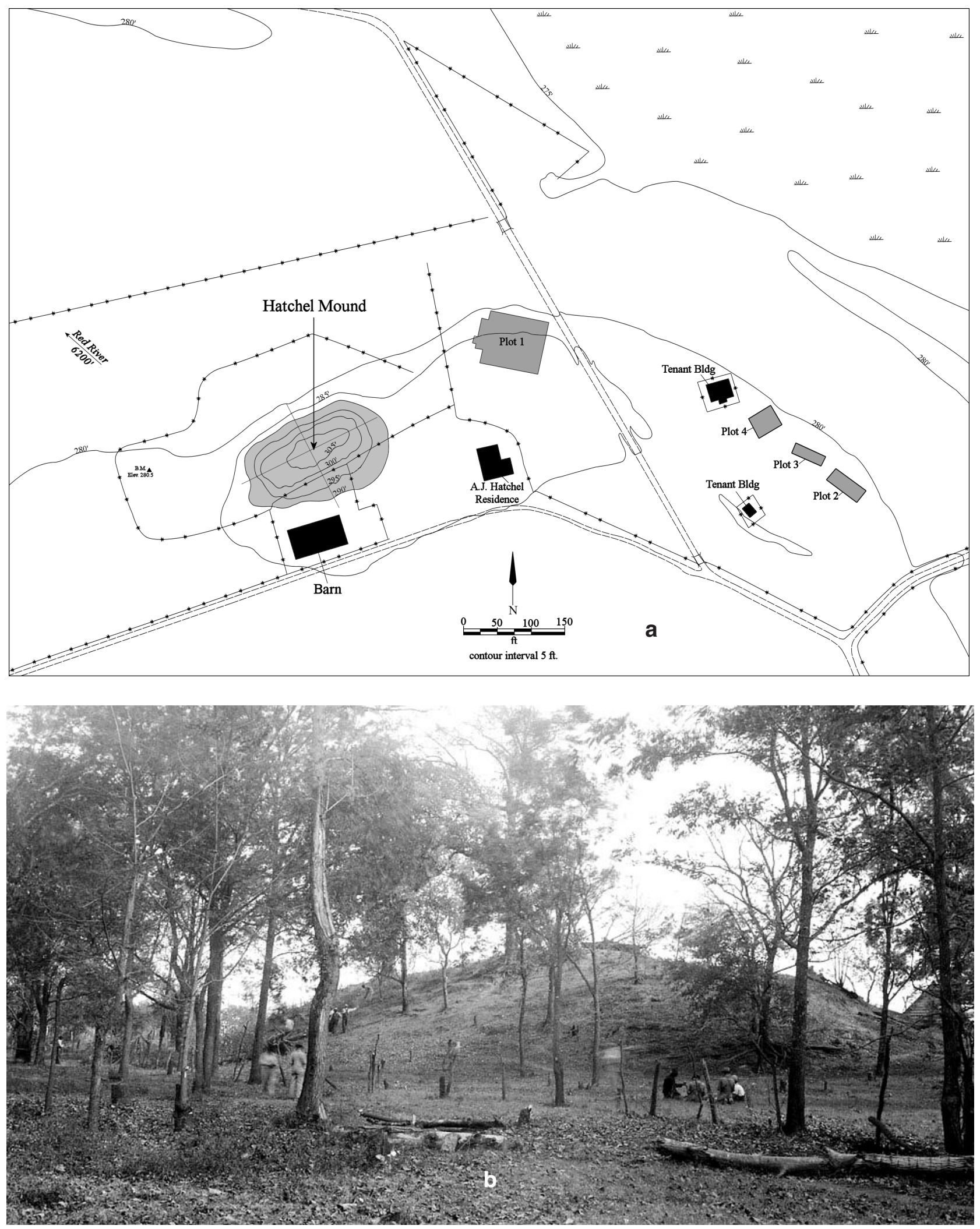

Figure 4. The platform mound at the Hatchel site: a, WPA map showing the Hatchel mound, Burial Plots 1-4, and 1938-1939 farm structures; b, looking south at the Hatchel platform mound from the edge of the Red River floodplain. Image 41BW3-9, Texas Archeological Research Laboratory, The University of Texas at Austin. 


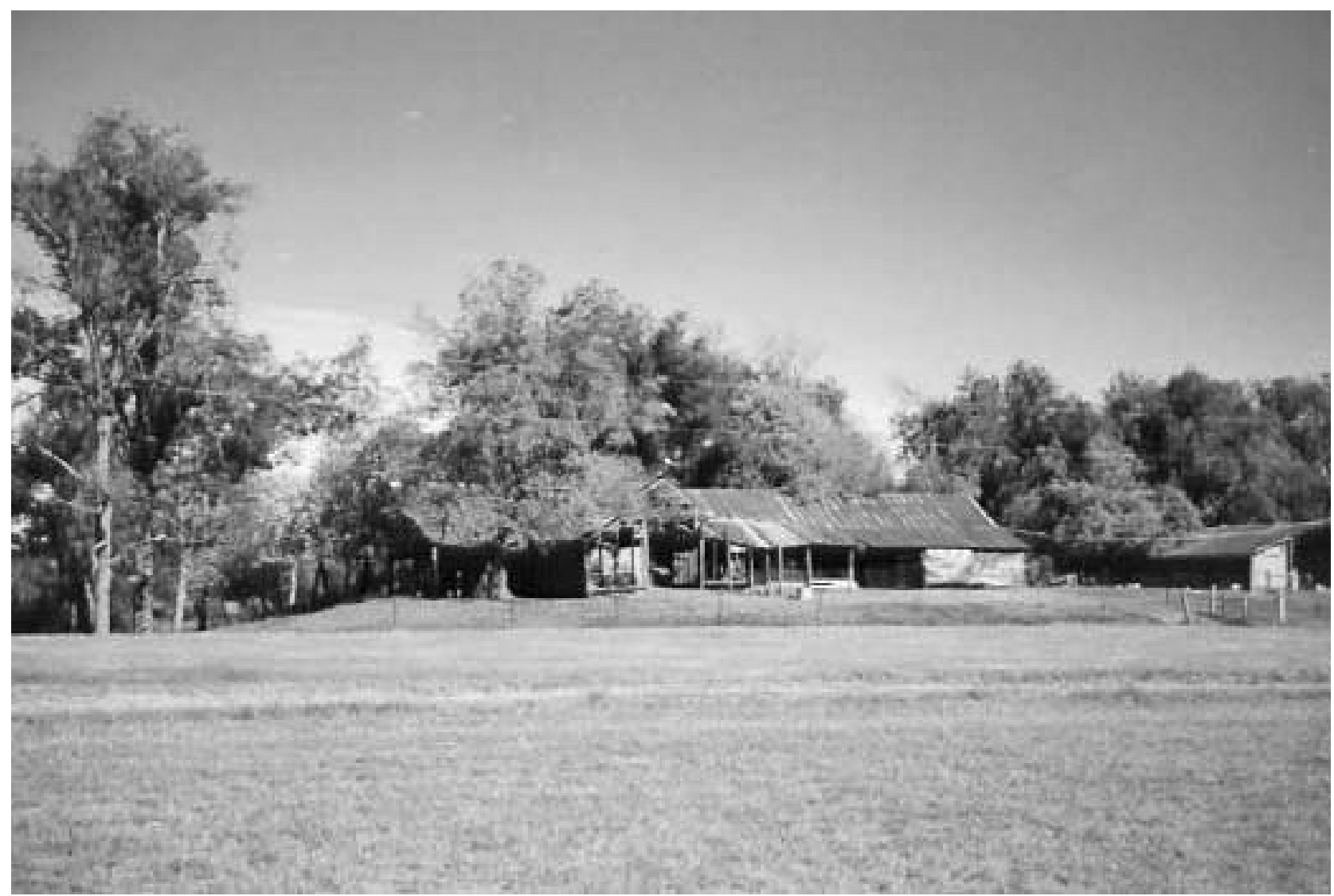

Figure 5. The remnant of the platform mound at the Hatchel site in 2003, with a barn standing on it.

The Caddo archaeological record is a one-thousand year record of cultural change and continuity among a variety of closely related peoples who maintained their own distinctive socio-political and economic dynamic while Mississippian polities in the Southeastern United States fought and competed for power and tribute. Archaeological research on the sites and sacred places left behind by the Caddo peoples since the early 1900s have rather convincingly demonstrated that the Caddo archaeological tradition should be understood and appreciated through its own long native history.

The Caddo archaeological and cultural tradition represents "an archaeological concept... recognizable primarily on the basis of a set of long-standing and distinctive cultural, social, and political elements that have temporal, spatial, and geographic connotations" (Perttula 1992:7). Best known for the distinctive and beautifully-made engraved ceramic vessels found on mound and habitation sites, the Caddo archaeological tradition in basic terms is characterized by dispersed but sedentary settlements of villages, hamlets, and farmsteads, the development through time of an horticultural to an agricultural economy dependent upon domesticated corn, beans, and squash, and a complex socio-political structure denoted principally by a complex network of mound centers and the differential treatment of the dead by rank or hierarchy, most notably in burial mound shaft tombs accompanied by elaborate kinds of grave goods, many of exotic origin (Brown 2010; Early 2000a, 2004; Girard 2010).

Caddo archaeologists have argued that the development of Caddo cultural traditions in prehistoric times took place relatively independently of the emergence of Mississippian cultural developments in 


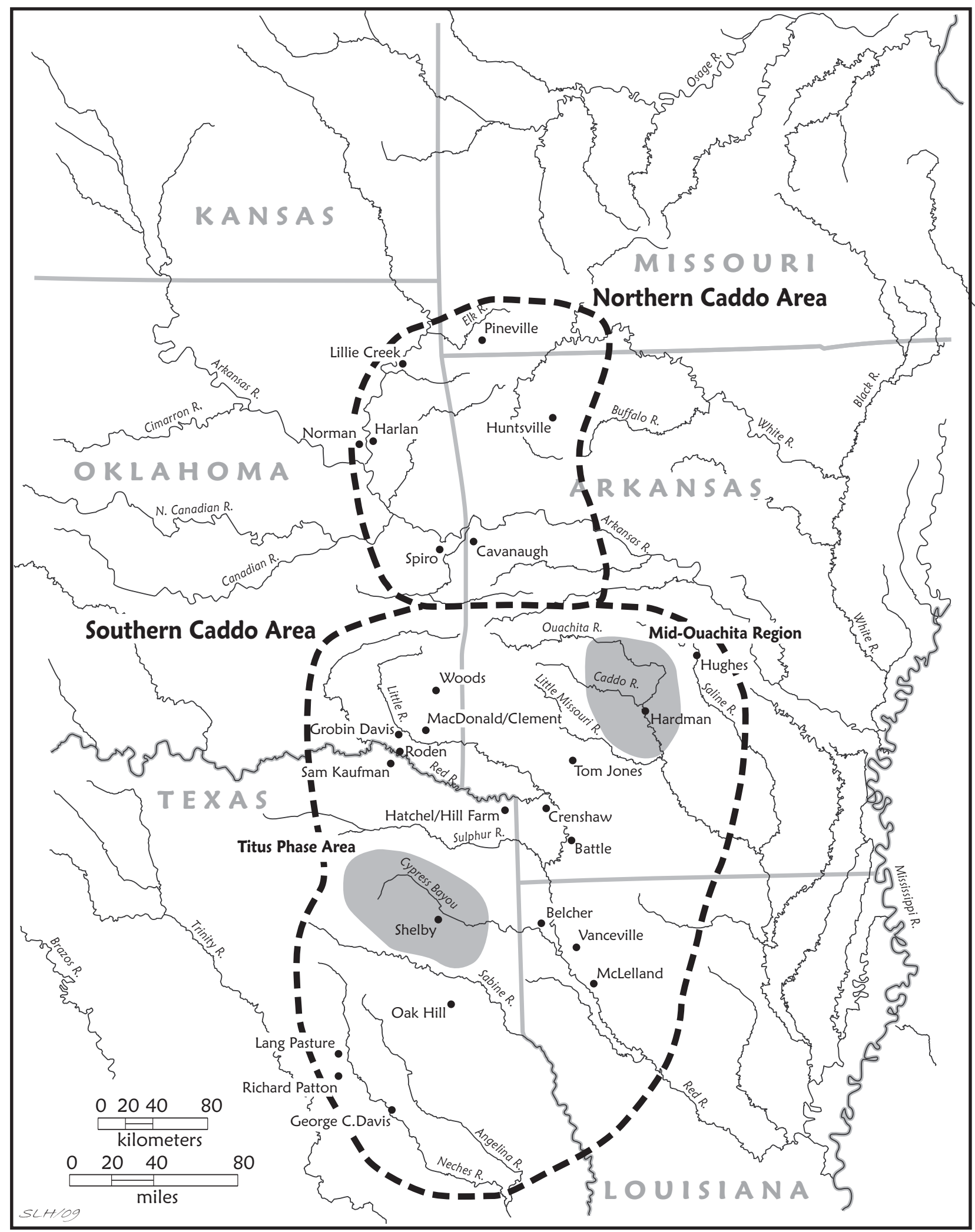

Figure 6. The southern and northern Caddo areas at their maximum extent ca. A.D. 1000 or thereabouts. Figure drawn by Sandra L. Hannum. 
the southeastern U.S. Archaeological research conducted over the past 40 years, in combination with the development of radiocarbon dating, has shown that the Caddo archaeological tradition began by about A.D. 800/900, out of an indigenous Woodland tradition of hunter-gatherer-gardener peoples. Caddo societies shared much with their Southeastern U.S. Mississippian neighbors, including the adoption of maize and the intensification of maize agricultural economies, an emphasis on monumentality (e.g., Anderson 2012), as well as in systems of social authority and ceremony (e.g., Blitz 2010; Butler and Welch 2006). Although there are clear socio-political and trade relationships with the Southeast and various Mississippian groups, the people living in the Caddo area are manifestly different in several intriguing ways. The Caddo archaeological record documents a millennium of native history among peoples who maintained their own distinctive socio-political, economic, and technological dynamic.

The principal occupation of this part of the Red River basin in East Texas in prehistoric and early historic times (up to about A.D. 1790) was by Caddo-speaking Indian groups that lived in settled horticultural and agricultural communities. These communities were composed principally of farmsteads and small hamlets, but larger villages, as at the Hatchel, Mitchell, Eli Moores (41BW2) and Cabe (41BW14) sites (see Figure 3), were situated along the Red River bottomlands during much of the prehistoric and historic era (e.g., Story 1990; Perttula 2005; Perttula et al. 1995), particularly during the Texarkana phase, the latest Caddo culture in the area (Creel 1996:505). Caddo archeological sites in the region are known to be primarily located on elevated landforms (alluvial terraces and rises, natural levees, and upland edges) adjacent to the major streams, as well as along spring-fed branches and smaller tributaries with dependable water flow. They are also located in proximity to arable sandy loam soils, presumably for cultivation purposes with digging sticks and stone celts.

These Caddo groups were powerful theocratic chiefdoms that built earthen mounds (like the platform mound at the Hatchel site, see Jackson 2004) for political and religious purposes, functions, and rituals, traded extensively across the region as well as with non-Caddoan speaking groups, and developed intensive maizeproducing economies by the $13^{\text {th }}$ century A.D. (Perttula et al. 2014). Due to diseases introduced by Europeans sometime after the mid- $16^{\text {th }}$ century, and the incursions of the Osage to obtain deer hides and Caddo slaves, by about 1790, the Red River valley in the Texarkana area was abandoned by Caddo groups.

\section{Caddo Architectural Context}

At least in East Texas, Caddo communities primarily constructed circular house and temple structures, as well as circular non-mound domestic structures, although there is an impressive diversity in these structures through time and across the Caddo landscape (e.g., Schultz 2010). The range of structure shapes in East Texas Caddo sites includes circular, sub-round, sub-square, and rectangular, with each architectural form found in both mound and non-mound contexts. Some of the circular structures associated with platform mounds, such as Feature 111 under Mound B at the George C. Davis site that was $18 \mathrm{~m}$ in diameter (Story 1997:Figure 34), the $14 \mathrm{~m}$ diameter structure at the A. C. Saunders site (Kleinschmidt 1982), and Feature 25 at the Hatchel site, $15 \mathrm{~m}$ in diameter (see below), were very large in size, at least twice the size of a typical domestic circular structure in a Caddo village.

\section{WPA Archaeological Investigations in the Platform Mound}

The 1938-1939 Works Progress Administration (WPA) archaeological work, from November 1, 1938 to August 25, 1939, completed at the Hatchel site was extensive, particularly in the main earthen mound and in village areas. The platform mound sat in the northern part of the village, with habitation deposits known well to its east, west, and south (Figure 7). At the time, the mound had mainly been grass-covered, with a few trees, and a small wood clapboard tenant structure stood off the western end of the mound (Figure 8). 


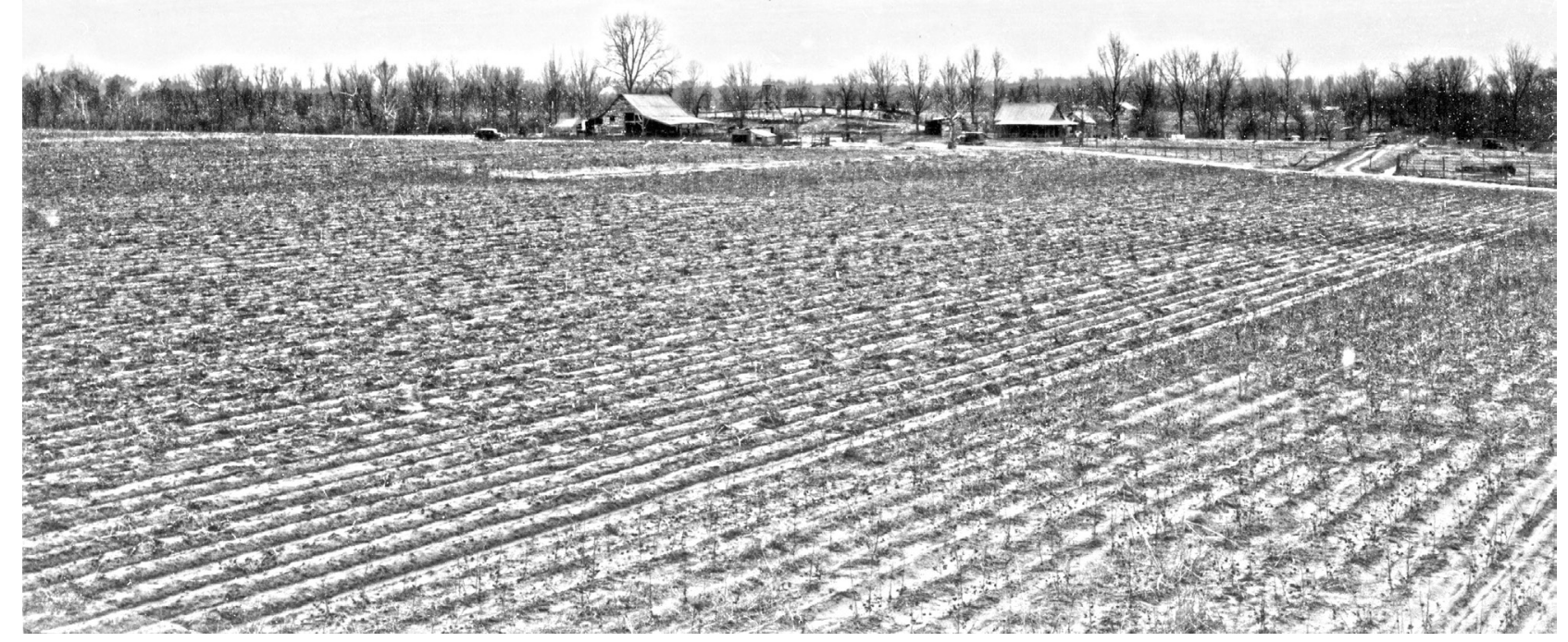

Figure 7. Looking north at village areas at the Hatchel site, with the platform mound in the distance, behind the barn. Image 41BW3-125, Texas Archeological Research Laboratory, The University of Texas at Austin.

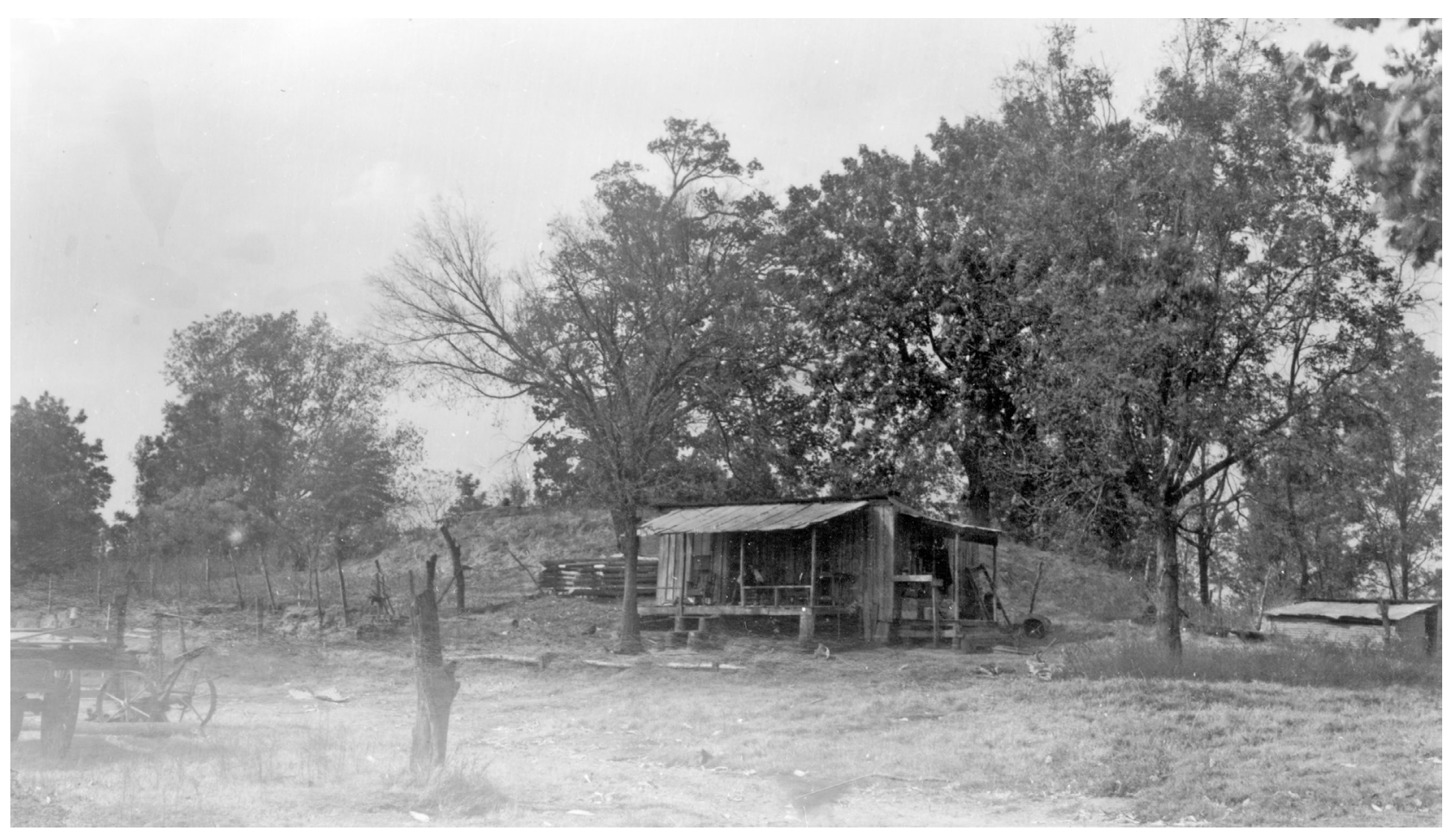

Figure 8. Looking at the western end of the platform mound before excavations were commenced. Image 41BW3-7, Texas Archeological Research Laboratory, The University of Texas at Austin. 
In the platform mound excavations, multiple "floors" or mound surfaces (referred to as zones, below) with house structures were recognized in the mound (Jackson 2003, 2004). The WPA work was done by 40-60 laborers and tenant farmers that lived in the local area. Mr. William C. Beatty was in overall charge of the excavations at the mound, assisted by Alden C. Hayes and E. Glenn Martin. The foremen included Robert T. Shelton, Willie C. Lynch, Arthur C. Jones, and Claude E. Dumis. Harry C. Dale and Clarence L. Markham worked as clerks (TARL n.d.:536).

In the excavations of the mound, the mound was first gridded into $5 \times 5 \mathrm{ft}$. squares, and the excavations proceeded in horizontal levels across the mound to completely expose and record structure post hole patterns and associated features on different mound platform surfaces (Figure 9). As the excavations proceeded in depth, the methods changed to one where half of the mound was excavated down by the WPA crew (Figure 10) to where the next structure floor zone was encountered, where the structures and features were mapped, then the excavations continued downward to the next structure zone, and the one after that, so as to obtain profiles after the features were excavated and recorded (TARL n.d.:533). After zone $\mathrm{H}$ was reached, the remaining half of the mound was then excavated down to that zone, recording the remaining features as they were exposed (Figures 11 and 12).

The lower portions of the mound (zones I and J) were excavated by the methods discussed above, augmented by trenching to reach the original ground surface under the mound before the WPA work was to end (Figure 13 and TARL n.d.:482, 531). When features were encountered in one area under the mound (in zone K), a large horizontal block was excavated to completely expose a very large circular structure that had been constructed in a habitation area at the ground level (see Figures 41-42, below).

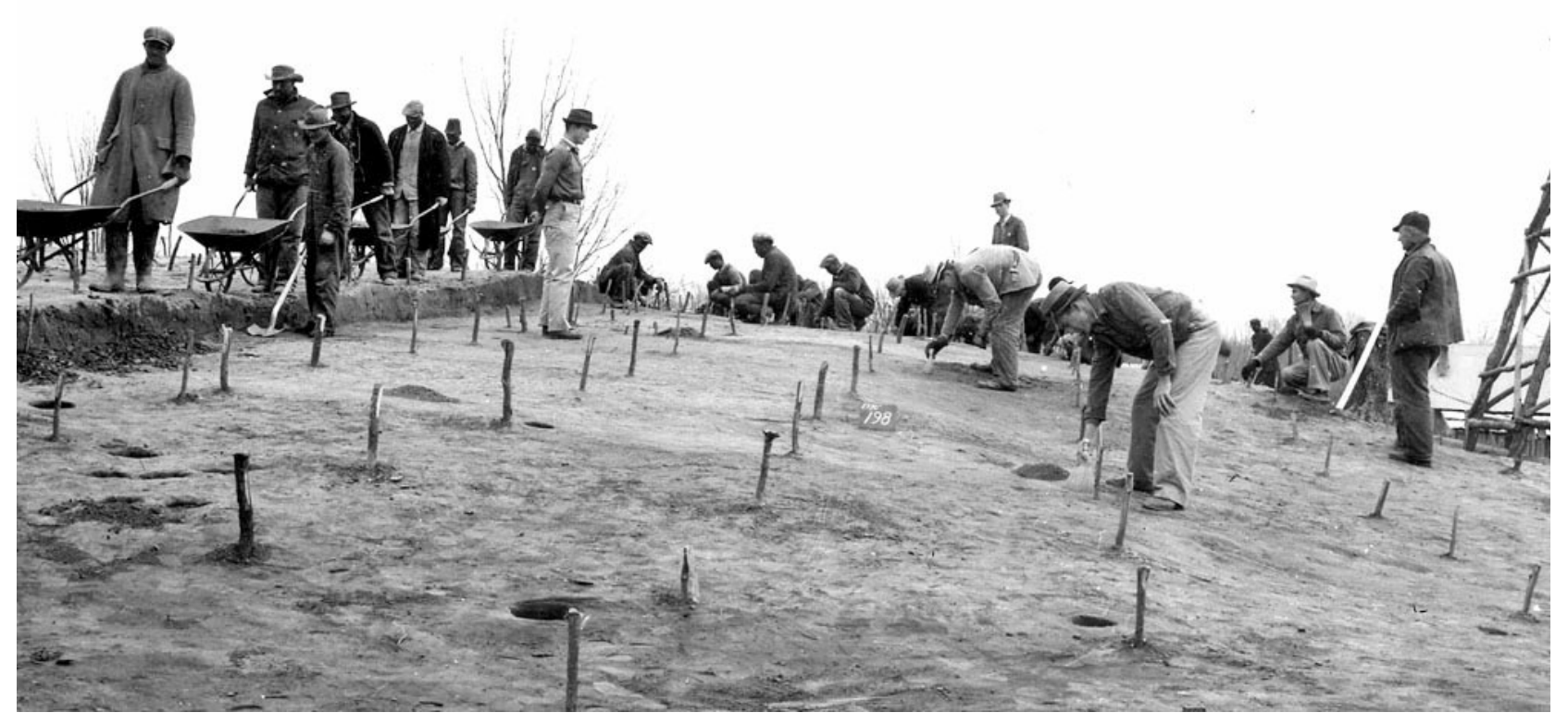

Figure 9. WPA crew excavating the uppermost deposits in the platform mound. Image 41BW3-121, Texas Archeological Research Laboratory, The University of Texas at Austin. 


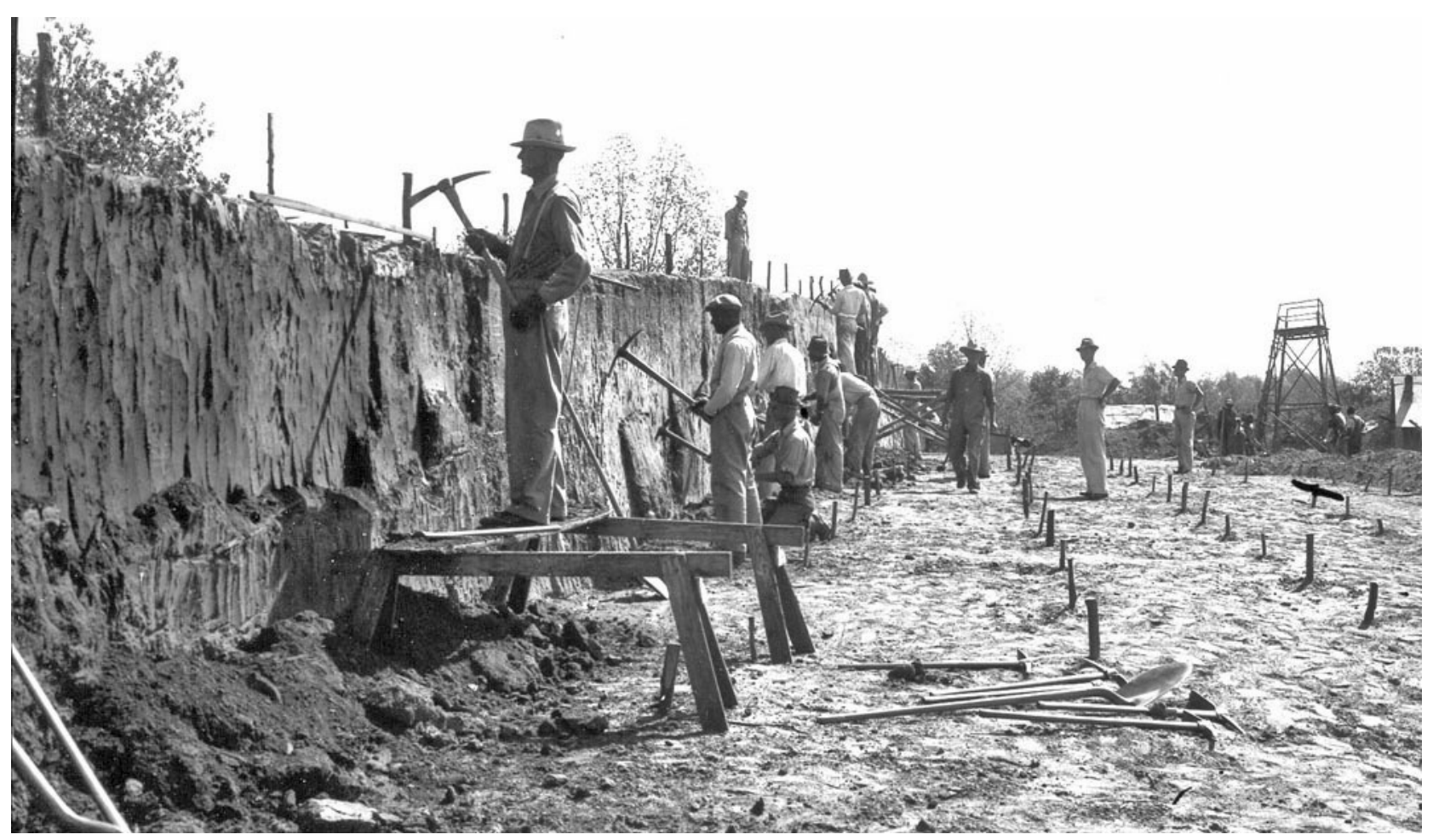

Figure 10. WPA crew excavating down through the mound, standing on Zone H. Image 41BW3-202, Texas Archeological Research Laboratory, The University of Texas at Austin.

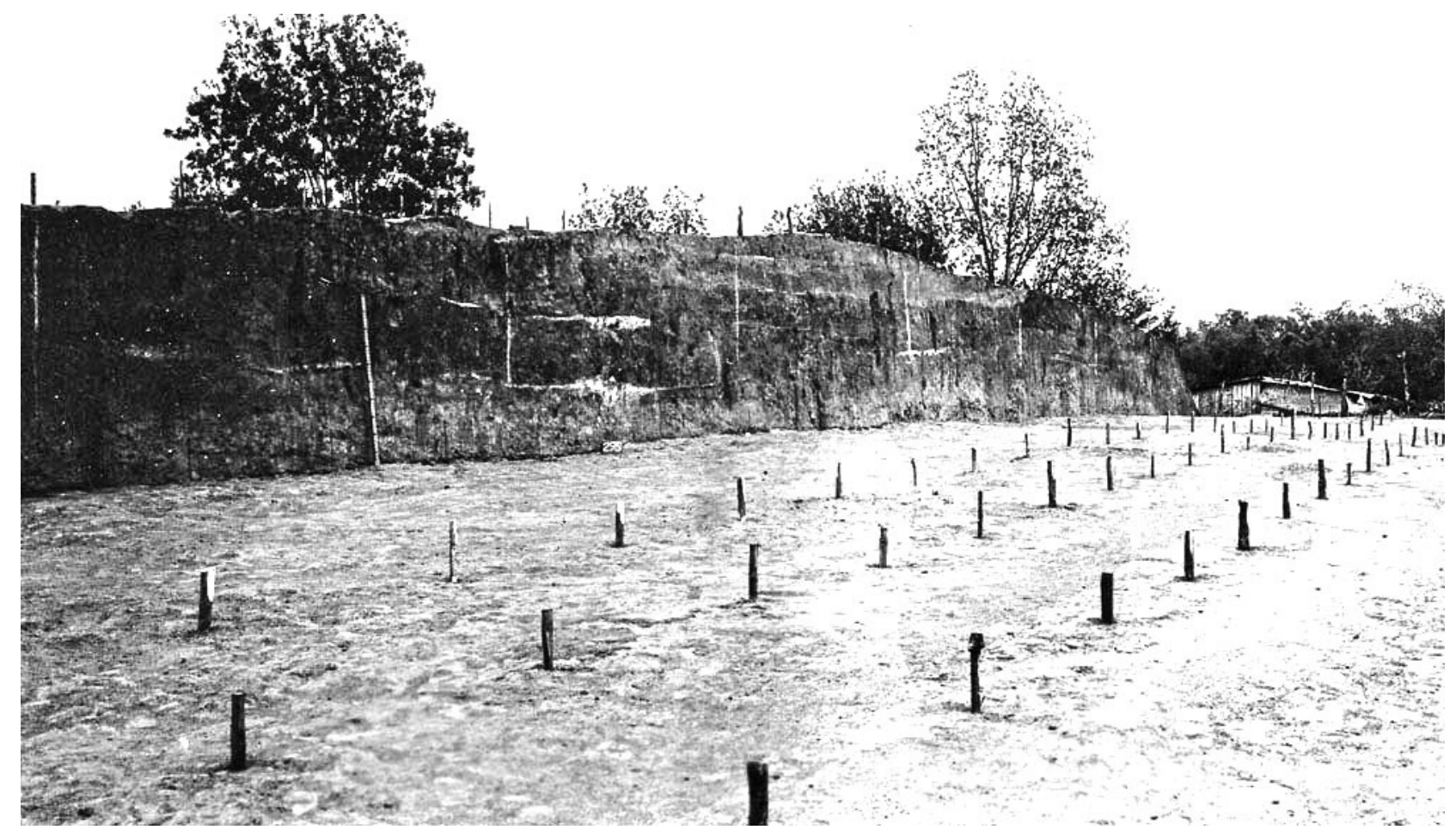

Figure 11. Length-wise cross-section of the platform mound from Zone H. Image 41BW3-219, Texas Archeological Research Laboratory, The University of Texas at Austin. 


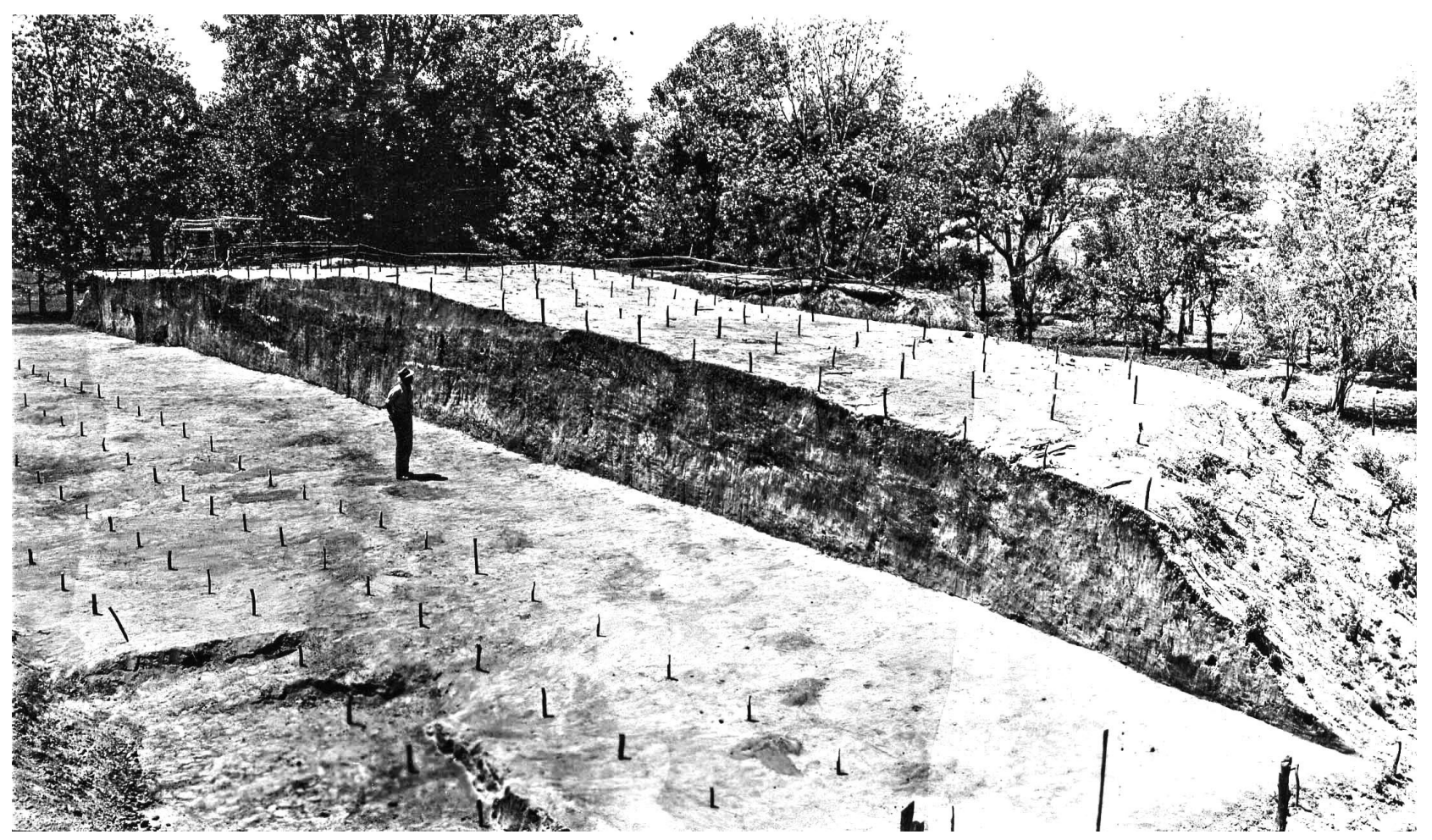

Figure 12. Profile of the platform mound, with the man standing on Zone H. Image 41BW3-207. Texas Archeological Research Laboratory, The University of Texas at Austin.

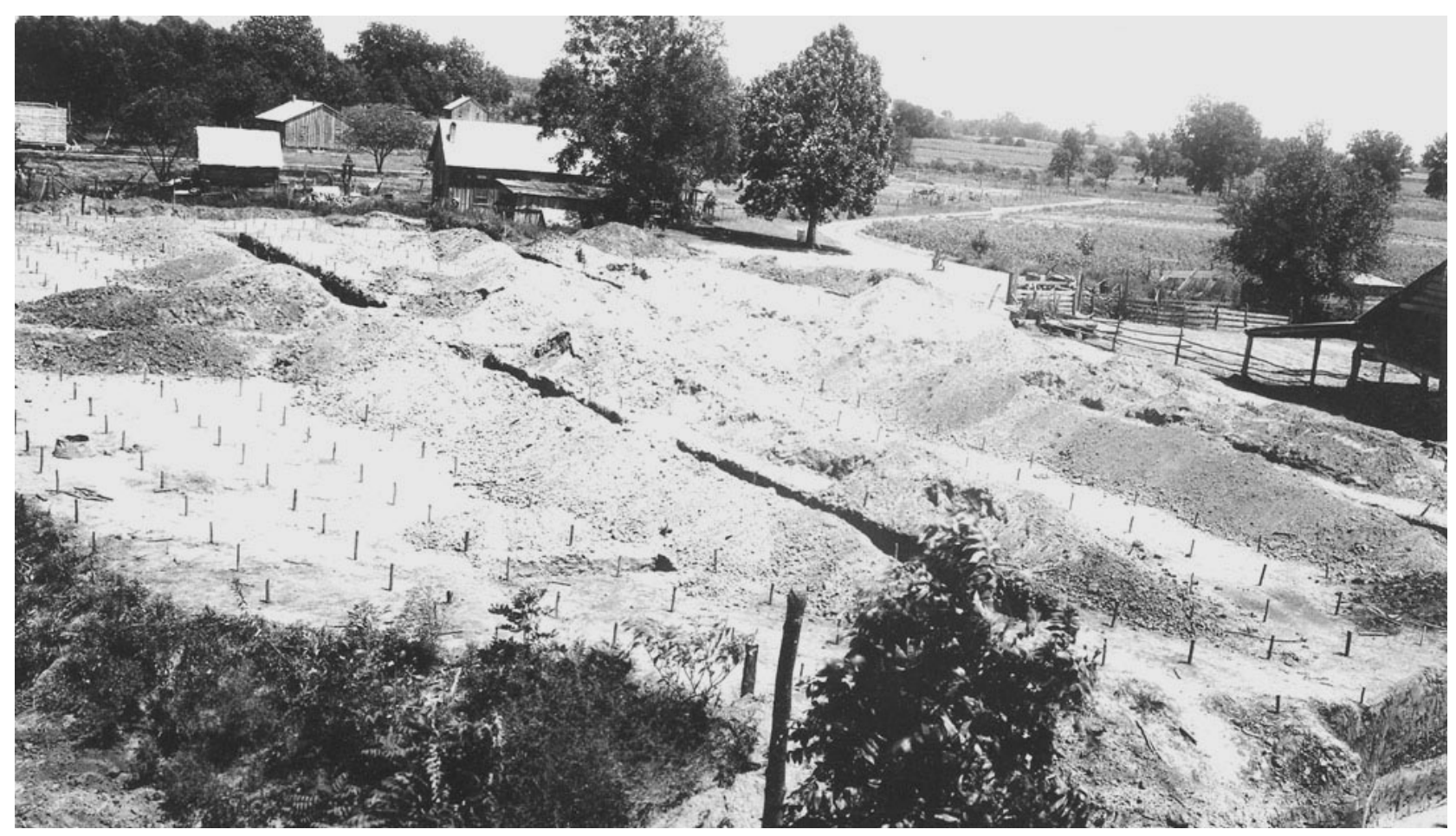

Figure 13. WPA trenches to reach the pre-mound surface. Image courtesy of the Texas Archeological Research Laboratory, The University of Texas at Austin. 


\section{Construction of the Platform Mound}

In its final form, the platform mound at the Hatchel site measured approximately $58 \mathrm{~m}$ in length (east-west) and $44 \mathrm{~m}$ in width (east-west). A WPA profile of the mound indicates that the mound zones (A-J) are $7.7 \mathrm{~m}$ in height. According to Jackson (2004), a large oak stood atop the mound that was 170 years of age (based on the number of its tree rings), suggesting the mound had not been used for at least 200 years, or ca. A.D. 1740 .

The mound was constructed in several stages (Figure 14a-b). The first, or principal platform comprises zones I and $\mathrm{J}$-built atop the ground surface (Zone $\mathrm{K}$ ) and a large pre-mound circular structure (Feature 25) - and these stood $4.2 \mathrm{~m}$ in height, with flat tops (TARL n.d.:539). Neither of these mound platform zones had structures constructed atop them. Zone J was comprised of red and blue clays and was about $22 \mathrm{~m}$ in length, $14 \mathrm{~m}$ in width, thus rectangular, stood $2.2 \mathrm{~m}$ in height, and had steep sides. It contained little in the way of cultural materials. Zone I, on the other hand, was built up from sandy loam deposits (TARL n.d.:367) - probably scraped up from the surrounding village deposits since no borrow pits have been identified at the site - and it contained an abundance of debris, especially ceramic sherds (Table 1). Zone I was piled atop Zone $\mathrm{J}$ and extended the mound until it was more than $40 \mathrm{~m}$ in length; it also had steep sides (TARL n.d.:367). According to Jackson (2004), a ramp was constructed on the south central side of the mound, leading down to the plaza and village, as part of the primary mound; Krieger (1946:213, fn42) also mentions a clay ramp on the south side of the mound, apparently associated with Zones I and J (see also TARL n.d.:367). Krieger (1946:211) considers each of these zones to represent two superimposed "flat-topped 'temple' mounds."

Table 1. Sherd density in the mound platform zones (from Laughlin 1940).

\begin{tabular}{lccc}
\hline Zone & Plain Sherds & Decorated Sherds* & Total Sherds \\
\hline A & 611 & 242 & 853 \\
B & 596 & 285 & 861 \\
C & 408 & 158 & 566 \\
D & 307 & 143 & 450 \\
E & 505 & 265 & 770 \\
F & 945 & 533 & 1478 \\
G & 1934 & 921 & 2855 \\
H & 4380 & 2157 & 6537 \\
I & 1436 & 746 & 2182 \\
J & 94 & 61 & 155 \\
K & 79 & 35 & 114 \\
\hline Totals & 11,295 & 5546 & 16,841 \\
\hline
\end{tabular}

*red-slipped sherds were not tabulated as decorated by Laughlin (1940)

At this point a second stage of the mound began to be constructed on the northern half of the primary mound platform (TARL n.d.:541-542). This stage, approximately $3.4 \mathrm{~m}$ in height and ca. $30 \mathrm{~m}$ in length, is comprised of eight stratified zones (A-H) (see Figure 14b) with structures and other features. Each zone was subsequently buried by sandy loam and/or clay mound fill deposits. Krieger (1946:211) erroneously considered these mound deposits and burned structure zones to be "a huge mantle of midden refuse not intentionally built up," rather than the repeated construction and destruction of important structures that were built atop mound fill zones covering earlier structures and their associated debris. 


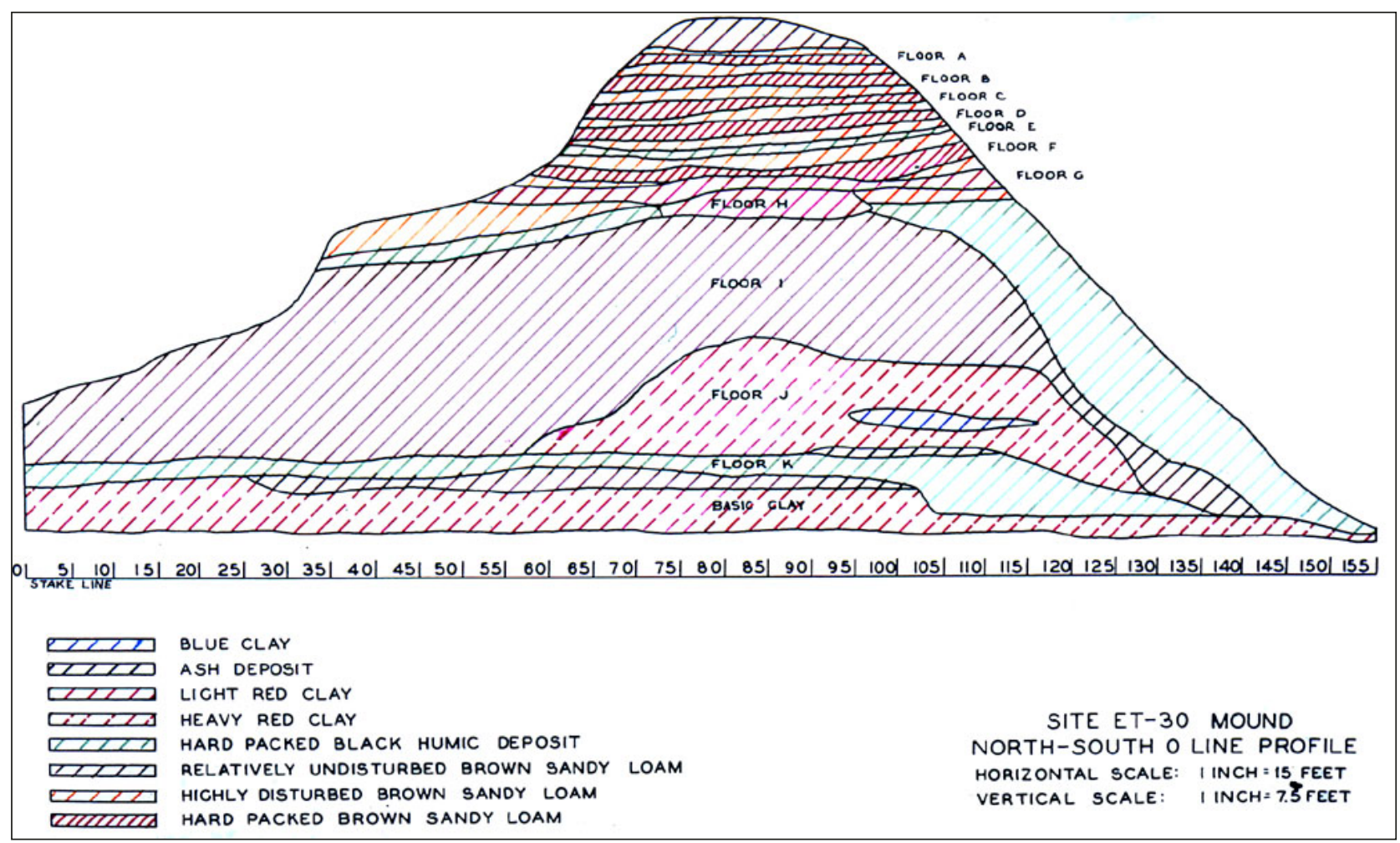

a

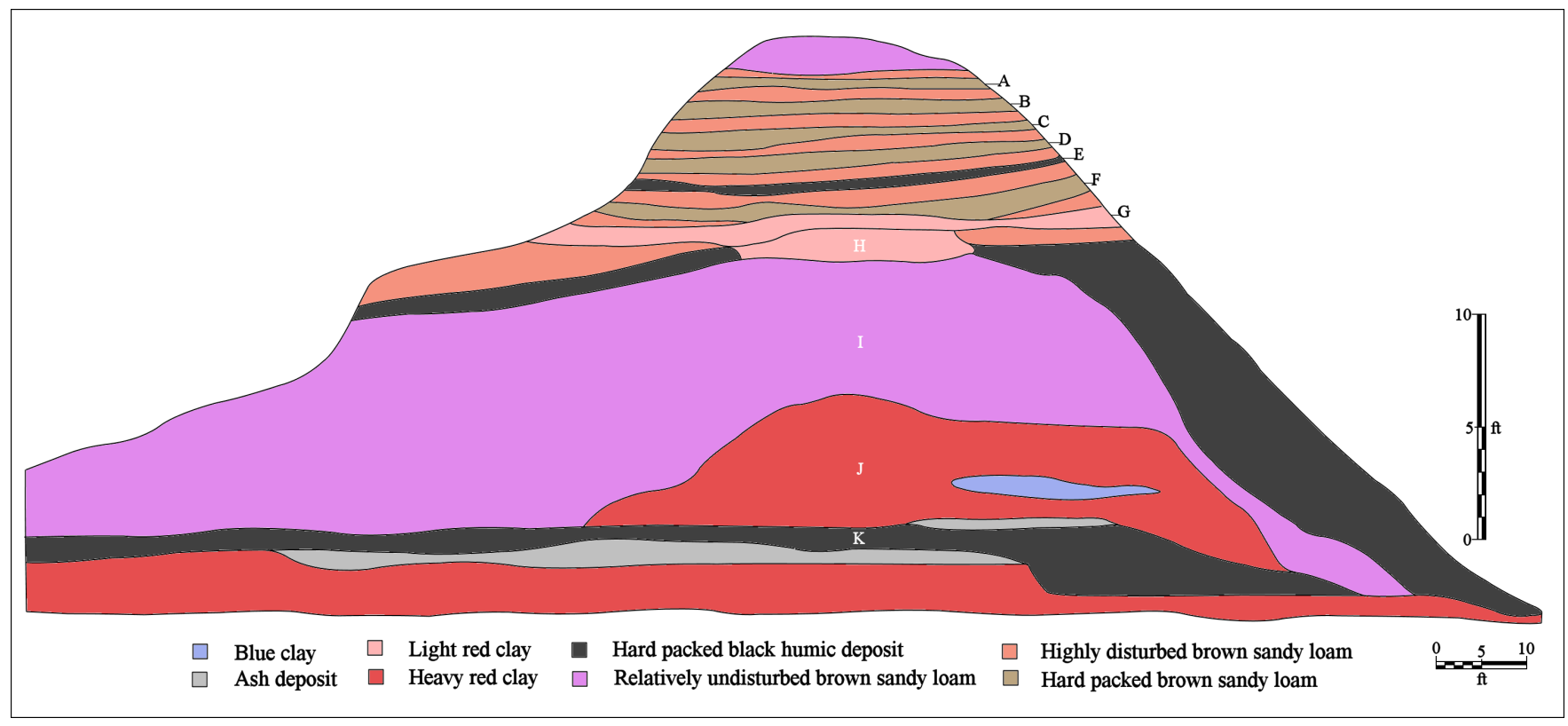

b

Figure 14. Cross-section of Zones A-K in the platform mound excavations at the Hatchel site: a, as originally drawn by WPA archaeologists; b, redrawn to more clearly depict the different zones in the platform mound. 


\section{Likely Age of the Platform Mound}

The construction and use of the platform mound has been thought to date to the Middle and Late Caddo period Texarkana phase occupation (ca. A.D. 1300-1690+) at the site. The mound was built over a large structure (Zone K) on a buried original ground surface (see Figure 14b), and a Crockett Curvilinear Incised vessel was found associated with this structure. The floor K structure was occupied sometime prior to ca. A.D. 1300, during the Haley phase (cf. Krieger 1946:213). However, the recovered sherds and arrow points from the platform mound do not indicate that the primary mound (Zones I and J) was also built sometime during the Haley phase (ca. A.D. 1200-1400), as Krieger (1946:213) had suggested, but that it first began to be built sometime after A.D. 1400, perhaps during the early part of the Texarkana phase.

Village Area II, not far south of the main earthen mound, has three calibrated radiocarbon dates on occupational debris that range from A.D. 1040-1280 at 2 sigma (Perttula and Nelson 2003:Table 15). The few available calibrated radiocarbon dates from the mound itself, on preserved wood from house features, range from, at 2 sigma, A.D. 695-869 (Floor K) to A.D. 1291-1392 (Floor B) (Perttula 1998:Table 1). These dates are at least several hundred years too old based on stratigraphic context and known artifact and burial associations in the mound floor zones. It is clear that a suite of new radiocarbon dates should be obtained from charred organic remains in each of the platform mound zones to accurately establish the age of each of the mound structure zones.

\section{Temple Structures on the Mound}

There are circular structures on each of the mound structure zones or floors (as the WPA archaeologists labeled them), from one to three structures per floor, that are considered temple structures and not ordinary domestic structures. The primary reason they are considered temple structures and not ordinary dwellings is the fact that the structures were built on the different mound platforms/zones, which is assuredly a special, if not sacred place, and they were regularly spaced across the different zones, with either a single central structure on a platform, or two structures on the east and west sides of the platform, with an open area between them, or there were three regularly spaced structures across a mound platform. Sometimes the structures were built right atop each other, although in different mound platforms/zones, so that the central point in each structure were superimposed over one another. Other reasons why these structures are likely temples and not dwellings include the character of the structures themselves, which generally lack central hearths, are not characterized by substantial amounts of midden debris inside them (although there are apparent midden deposits outside the structures in several mound structure zones), and frequently they have distinctive extended entranceways or internal/exterior partitions. The former were likely extended to both limit access to the structures themselves and remind those that entered of the special buildings they wished to seek ingress to and the special rituals carried out there, while the latter would have kept areas separate within the structure, or limited direct access to the structure entranceway.

Some of the structures are better preserved than others, and have readily interpretable post hole patterns (Table 2). The remaining structures have clusters and arcs of post holes, suggesting there were structures on different floors or zones that may have been rebuilt or torn down before they were covered with another mound fill deposit. It is not known if each of the structures identified in the different mound structure zones were occupied simultaneously or not, but if they were not contemporaneous, their occupations doubtlessly were not separated by many years. 
Table 2. Characteristics of the clearly defined structures on the platform mound at the Hatchel site (after Schultz 2010:Table 20).

\begin{tabular}{|c|c|c|c|c|c|}
\hline Zone & $\begin{array}{c}\text { Feature } \\
\text { No. }\end{array}$ & Shape & $\begin{array}{l}\text { Diameter } \\
\text { (m) }\end{array}$ & $\begin{array}{l}\text { Area } \\
\left(\mathrm{m}^{2}\right)\end{array}$ & Comments \\
\hline $\mathrm{A}$ & 1 & circular & 9.14 & 65.67 & extended entrance \\
\hline $\mathrm{B}$ & 5 & circular & 3.66 & 10.51 & probable granary \\
\hline $\mathrm{C}$ & 7 & circular & 9.14 & 65.61 & extended entrance \\
\hline $\mathrm{D}$ & 12 & circular & 8.87 & 61.79 & \\
\hline \multirow[t]{2}{*}{$\mathrm{E}$} & 13 & circular & 9.06 & 64.47 & \\
\hline & 14 & circular & 8.84 & 61.36 & $\begin{array}{l}\text { extended entrance; possible } \\
\text { prepared clay floor }\end{array}$ \\
\hline $\mathrm{F}$ & 15 & circular & 9.75 & 74.72 & extended entrance \\
\hline \multirow[t]{2}{*}{ G } & 22 (outer) & circular & 10.72 & 82.03 & double-walled \\
\hline & 22 (inner) & circular & 8.53 & 57.15 & \\
\hline \multirow[t]{4}{*}{$\mathrm{H}$} & 16 & circular & 7.32 & 42.03 & extended entrance \\
\hline & 17 & circular & 6.40 & 32.18 & partition to Structure $16 ?$ \\
\hline & 18 & circular & 8.60 & 58.03 & extended entrance \\
\hline & $19 / 20$ & circular & 12.00 & 113.1 & double-walled \\
\hline
\end{tabular}

A number of the circular structures on several of the floors have extended entranceways marked by lines of posts (see Table 2). These entranceways are oriented to the south or southeast, towards the likely main part of the village, or perhaps towards as well the single mounds at the Hill Farm (41BW169, see Perttula et al. 2008) and Dogwood (41BW226, see Sundermeyer et al. 2008:242-253) sites that are also part of the Nasoni Caddo community centered at the Hatchel site (see Figure 1). In most instances, as will be discussed in further detail, on East Texas Caddo sites (and in most parts of the southern and northern Caddo areas), extended entranceway structures mark special purpose structures - sanctified places of ritual and ceremony - where access was deliberately limited (Perttula 2009), and these extended entranceway structures on the platform mound at Hatchel appear no different.

\section{Floor A}

There is one clear circular structure on this top mound structure zone, Feature 1 (Figure 15). It is situated on the east side of the mound, and has a poorly defined wood post extended entranceway that faces to the southeast. Within Feature 1 is a large (ca. 3-4 $\mathrm{m}$ in diameter) concentration of ash (part of a burned floor deposit), and there are several patches of daub along the wall line and a few mest of the western wall, along what may be an exterior partition. The daub may be part of the collapsed roof (TARL n.d.:136). 


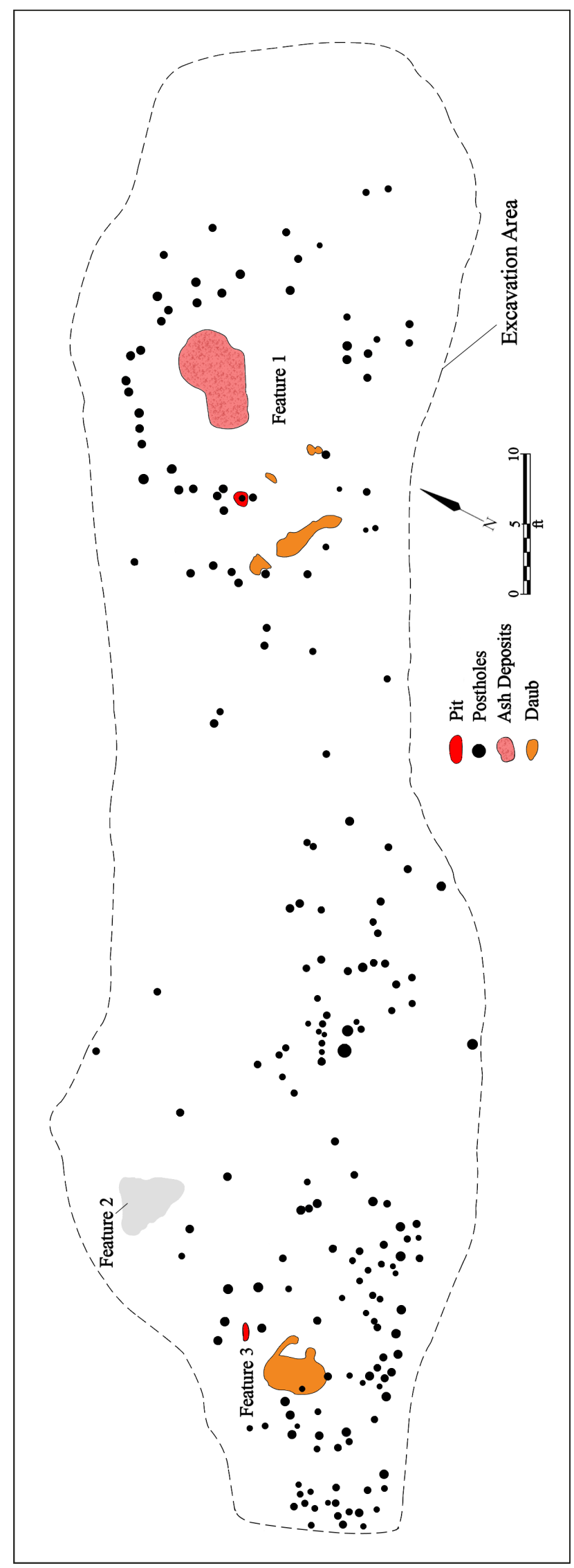

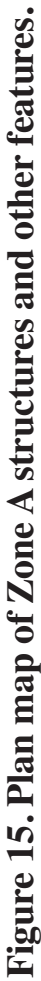


A second area of structures is represented by the mass of post holes and one area of daub (approximately 5-13 cm in thickness, TARL n.d.:130) associated with Feature 3 at the western end of the platform mound (see Figure 15). No clear circular structure pattern can be deciphered from the many arcs of post holes in this area, but it is suspected that the post holes here represent at least two different and rebuilt structures; there are no obvious entranceways. The daub likely represents the burned clay and thatch of a collapsed roof to one of the structures in this area (TARL n.d.:141). A large pit feature (Feature 2) is located several $\mathrm{m}$ north of the Feature 3 post holes.

There is a third smaller cluster of post holes between Features 1 and 3 that may represent a ramada or elevated platform. One group of post holes form a roughly rectangular area about $3 \times 3 \mathrm{~m}$ in size (see Figure 15). Feature 2, northeast of Feature 3, is a large $(1.5 \times 1.2 \mathrm{~m})$ storage pit (TARL n.d.:131).

\section{Floor B}

Zone B lies approximately $30 \mathrm{~cm}$ below the features in Zone A. Arcs of post holes to at least three closely-spaced circular structures are apparent in the central and eastern part of Zone B on the platform mound, although none of the patterns of post holes with any of these structures are particularly well defined (Figure 16). Feature 5, in the center of the zone, is estimated to have a diameter of only $3.66 \mathrm{~m}$ (see Table 2), in the size range consistent with features identified as granaries at sites such as George C. Davis (41CE19), Musgano (41RK19), and Oak Hill Village (41RK214) (Schultz 2010). It appears to have a short extended entranceway that faces to the south. WPA notes describe it as having a deep red burned floor (TARL n.d.:156).

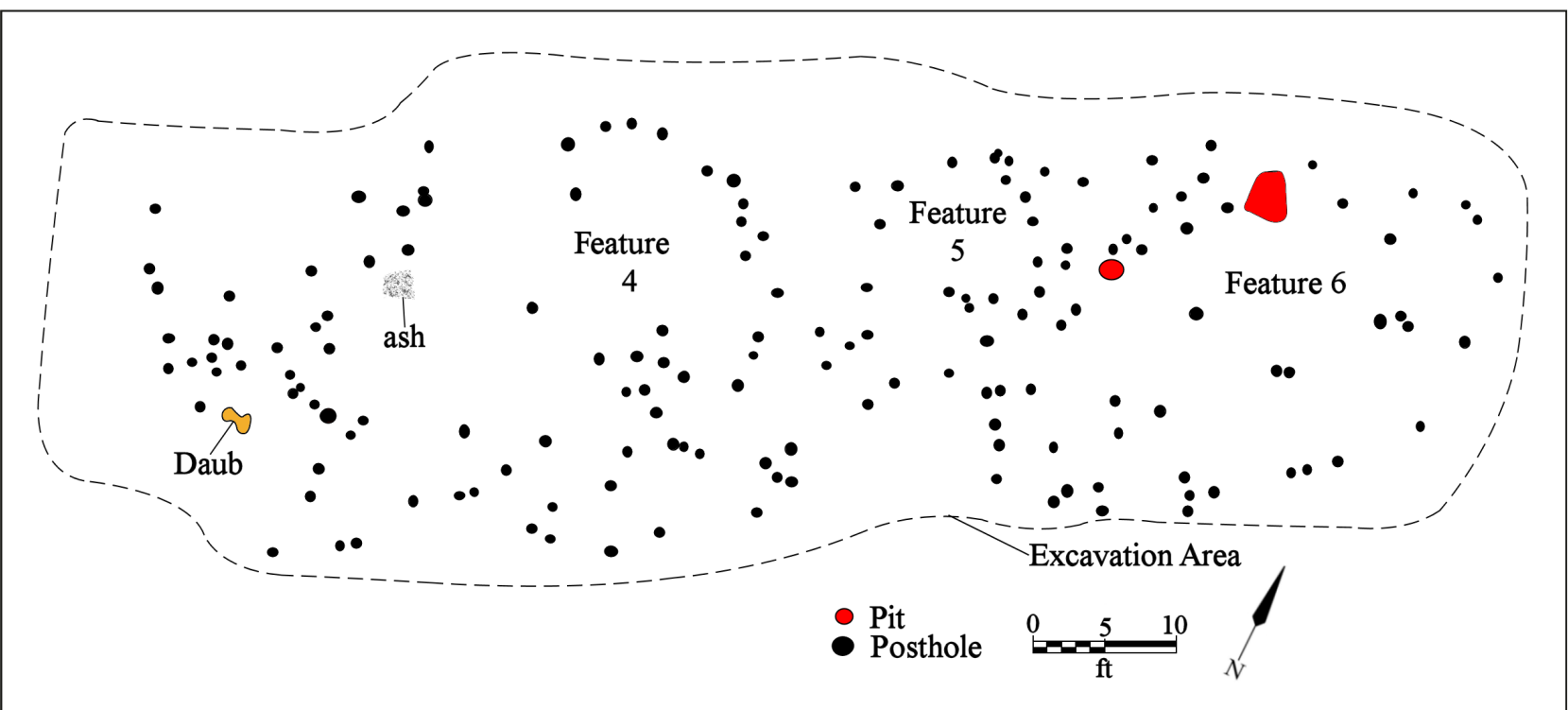

Figure 16. Plan map of Zone B structures and other features.

The number of post holes that are labeled Feature 4 by the WPA archaeologists may be from a large (ca. $8 \mathrm{~m}$ in diameter) circular structure that may have an extended entranceway facing south, or the arcs to two different and smaller circular structures (see Figure 16). Near the western arc of post holes is a interior hearth marked by ash deposits resting on and above the floor as well as a partially burned floor (TARL n.d.:144, 152), and there is a small pile of daub (ca. 6-7 cm thick) outside of that arc. There are two pit features, one a large storage pit (TARL n.d.:145), associated with Feature 6. 


\section{Floor C}

The one clear structure in Zone $\mathrm{C}$ is Feature 7, a circular structure $9.14 \mathrm{~m}$ in diameter, with a central hearth $(1.2 \times 1.0 \mathrm{~m}$ in size and $43 \mathrm{~cm}$ in depth below the floor), a hard-packed clay floor (ca. $12 \mathrm{~cm}$ thick) (TARL n.d.:164) and the fallen roof of a wattle and daub-covered extended entranceway (Figure 17). Zone $C$ is approximately $30 \mathrm{~cm}$ below the top of Zone B (TARL n.d.:163). The extended entranceway to Feature 7 is about $2.5 \mathrm{~m}$ in length and is oriented to the southeast. Arcs of post holes about $1.5 \mathrm{~m}$ from the eastern and southern walls of Feature 7 may represent portions of an exterior partition or screen (TARL n.d.:171), similar to Features 16 and 17 in Zone H (see below).

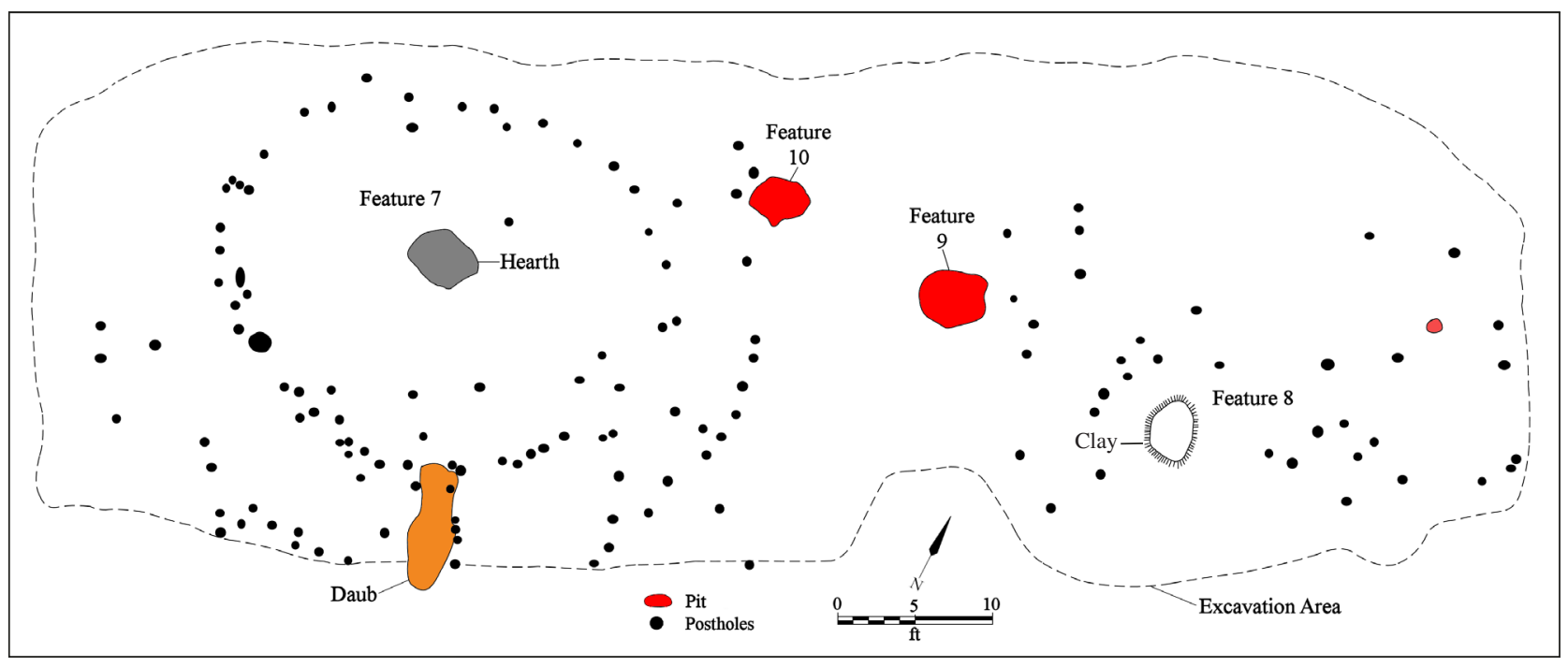

Figure 17. Plan map of Zone $\mathrm{C}$ structures and other features.

There are two storage pits $(1.3 \times 1.1 \mathrm{~m}$ and $1.2 \times 1.0 \mathrm{~m}$ in size, respectively) filled with trash (Features 9 and 10) between Feature 7 and Feature 8 (see Figure 17). Feature 9 had "hard packed clay sides and floor" (TARL n.d.:178). Feature 8 is marked by a number of post holes, but again they do not form a clear post hole structure pattern. There is a ca. $4 \mathrm{~m}$ circular arc that may be the best evidence for a circular structure on this part of the mound landform. This arc partially surrounds a $1.2 \times 0.9 \mathrm{~m}$ elevated (ca. $13 \mathrm{~cm}$ ) block of "slightly burned clay" (TARL n.d.:176) that may mark a specialized interior feature within the structure (see Figure 17).

\section{Floor D}

Neither of the two structures in Zone D have clear post hole patterns. Feature 11 is estimated at being a ca. $9 \mathrm{~m}$ circular structure on the central part of the mound platform (Figure 18), but the number of closely-spaced post holes in the southern part of this feature suggests that portions of it were rebuilt.

Portions of the wall post hole arc of Feature 12 are apparent in Zone D (see Figure 18), along with a central hearth and several areas of charred wood/charcoal. No clear entrance is apparent. One of these charcoal areas is ca. $1.8 \mathrm{~m}$ long, and just outside the southern wall arc (see Figure 18); the floors to either structure were not burnt (TARL n.d.:183). There are several small pits associated with both Features 11 and 12 . 


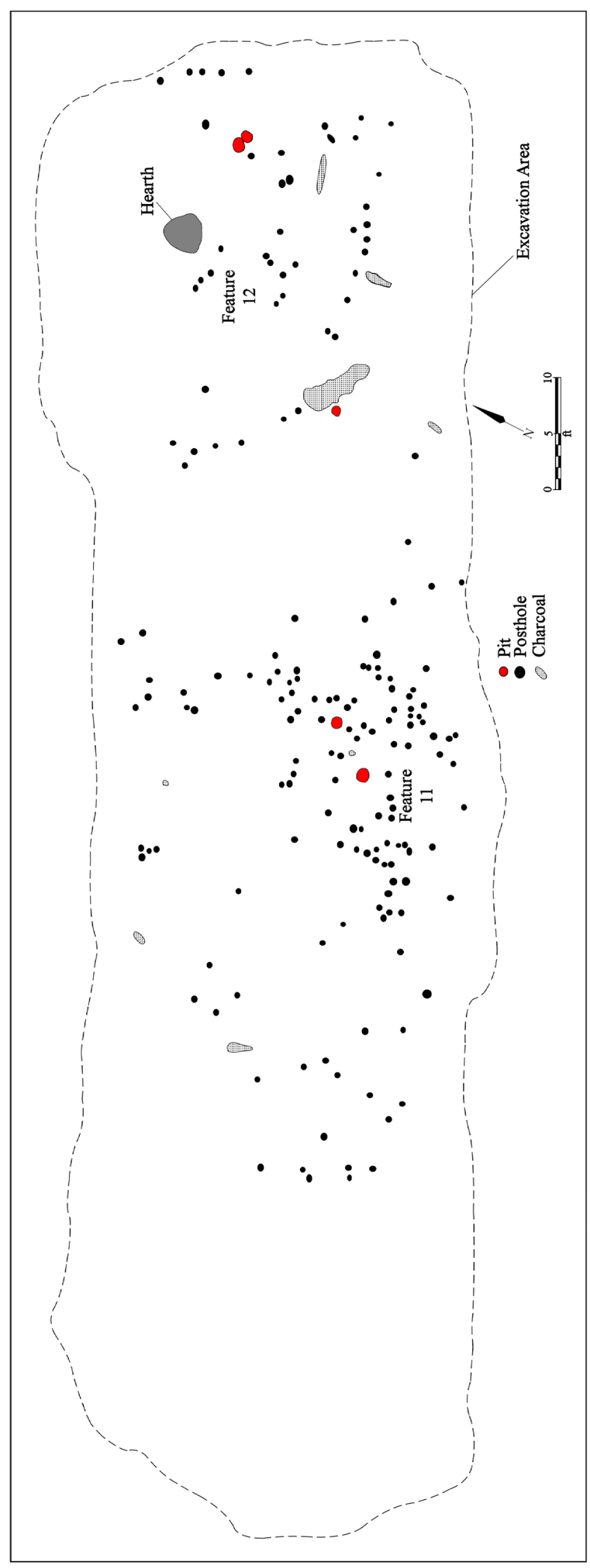

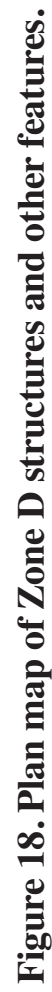




\section{Floor $E$}

There are two relatively clear circular structures in Zone E: Features 13 and 14. Both are roughly the same size (Figure 19), ranging in diameter from 8.84-9.06 $\mathrm{m}$ and from 61.36-64.47 $\mathrm{m}^{2}$ in area (see Table 2). They are situated in the central and western portions of the Zone E platform, while the eastern portions of the mound platform has a scattering of post holes (perhaps from a ramada or granary), one large pit feature, several small pits, and Burial 1 (Figure 19). The few post holes that contained charcoal suggest that the "posts were burned to the level of the floor" (TARL n.d.:200) when the structures were burned down.

Feature 13 has two associated ash deposits, several lengthy charcoal pieces, and two internal pit features (see Figure 19); there are also "black humic" or midden deposits associated with this feature (TARL n.d.:214). There is no obvious entranceway. Feature 14 may have had a prepared red clay floor (TARL n.d.:218), but no central hearth. There are several large pit features near the northern and eastern walls. There are also several post holes and a log beam impression that suggest this structure had an entranceway facing to the southeast (see Figure 19), as well as a single post that may have deliberately blocked the entrance. There are a number of post holes, as well as an ash deposit, between the apparent walls of Features 13 and 14 (see Figure 19), but it is not clear what they represent structurally.

\section{Floor F}

The central part of the Zone F mound platform, lying ca. $30 \mathrm{~cm}$ below Zone E (TARL n.d.:238), is dominated by a single large (9.75 $\mathrm{m}$ in diameter) circular structure (Feature 15) with a hard packed floor, and with a $1.3 \mathrm{~m}$ extended entranceway that faced to the southeast (Figures 20 and 21). The remnants of two unburned cedar posts were found in two of the post holes in the entranceway (TARL n.d.:248). Within the structure is one small ash deposit $(0.6 \times 0.46 \mathrm{~m}$ in size $)$ and four WPA-identified pits (TARL n.d.:249); it is probable that these pits represent four support posts for the structure. After Zone G mound deposits were laid down, Feature 15 was built directly over Feature 22 in Zone G.

The rest of the Zone F mound platform is open. There is one large ash deposit (ca. $1.0 \times 0.9 \mathrm{~m}$ in size) about $6 \mathrm{~m}$ east of Feature 15, as well as six large patches of a "black humic deposit" to the immediate south, east, and west of the structure; these may represent localized midden deposits. Burial 2 is more than $10 \mathrm{~m}$ east of Feature 15. Finally, there is a $4 \mathrm{~m}$ long arc of post holes about $5.5 \mathrm{~m}$ west of Feature 15 (see Figure 20); this may represent a screen or partition, or a part of a second poorly preserved structure on Zone F.

\section{Floor $G$}

The one structure in Zone G, Feature 22, was built directly over Structure 18 in Zone H (see Figure 24 , below), and is situated in the center of the mound platform (Figure 22); it lies about $30 \mathrm{~cm}$ below Zone F (TARL n.d.:264). The structure has two arcs, and sometimes three arcs (on the western side of the structure), of post holes, suggesting it had double walls of posts (Figure 23). The double walls are 8.53 and $10.22 \mathrm{~m}$ in diameter. There is no clear entrance for Feature 22, although there is a large gap without post holes in the southern wall. The structure has a central hearth (with a $50 \mathrm{~cm}$ deep basin, TARL n.d:274) and associated ash deposits, as well as a small pit in the northwestern quadrant.

There are large areas of apparent midden deposits ("black humic sand" in WPA records) covering much of Zone G outside of Feature 22 (see Figure 22); the remainder of the zone was a light red clay that 


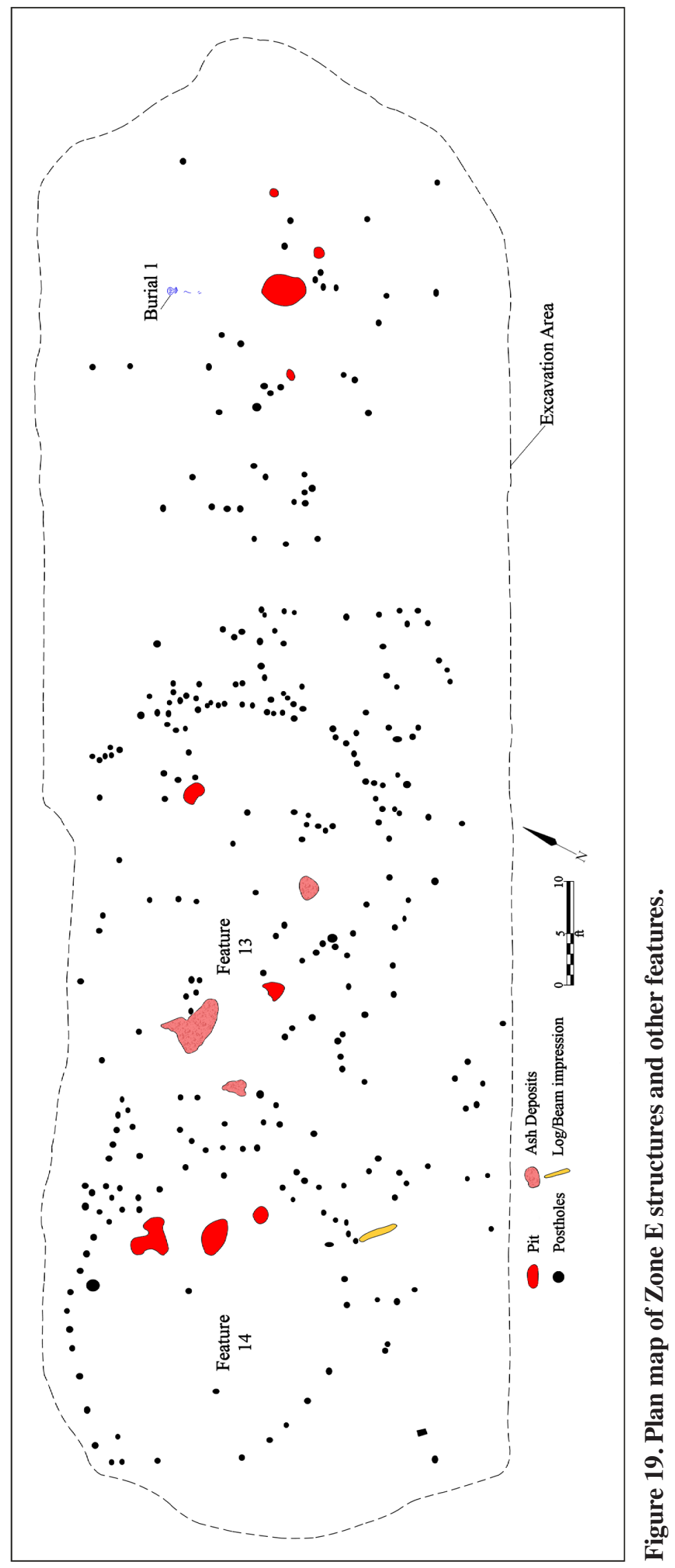




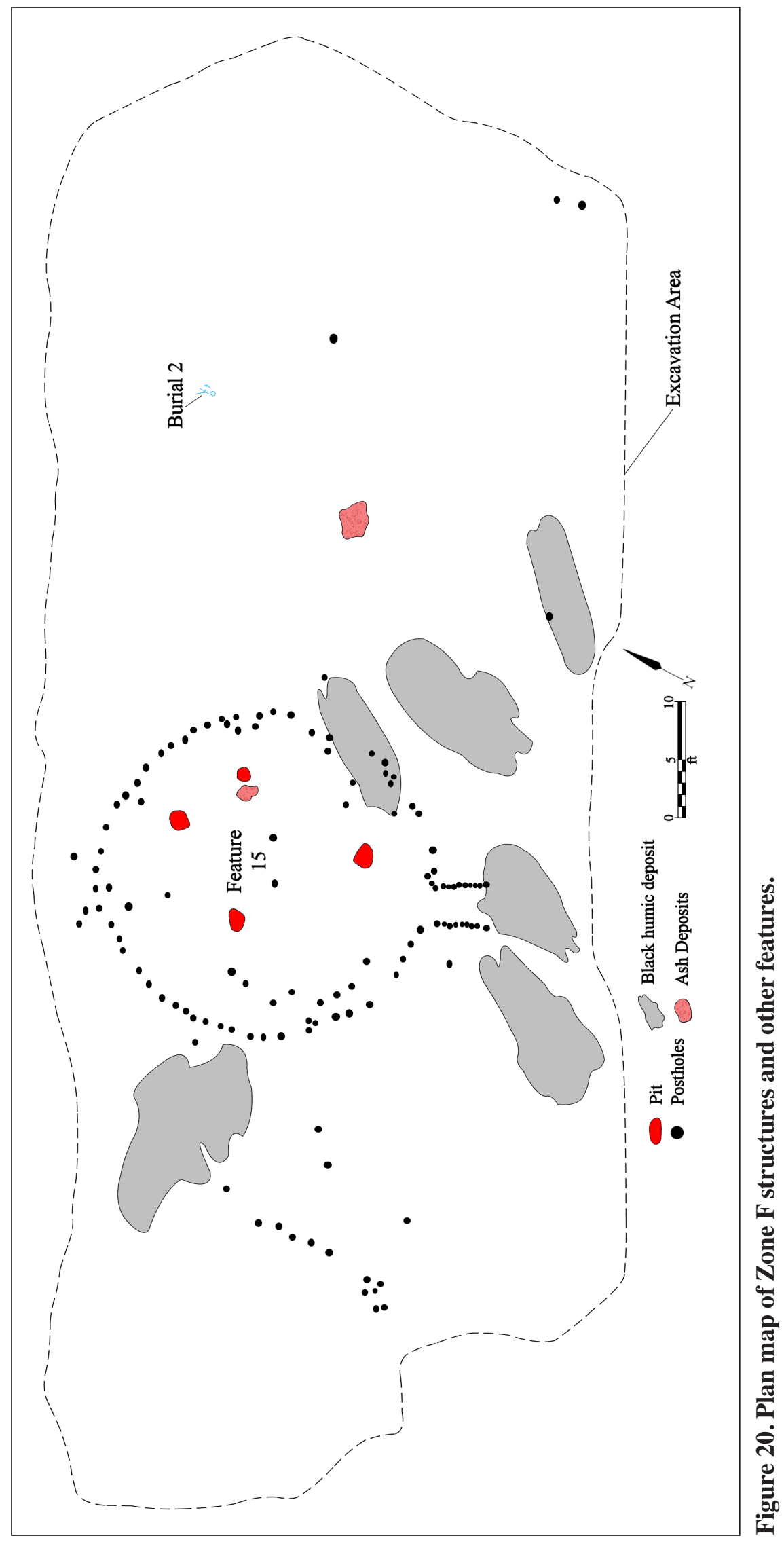




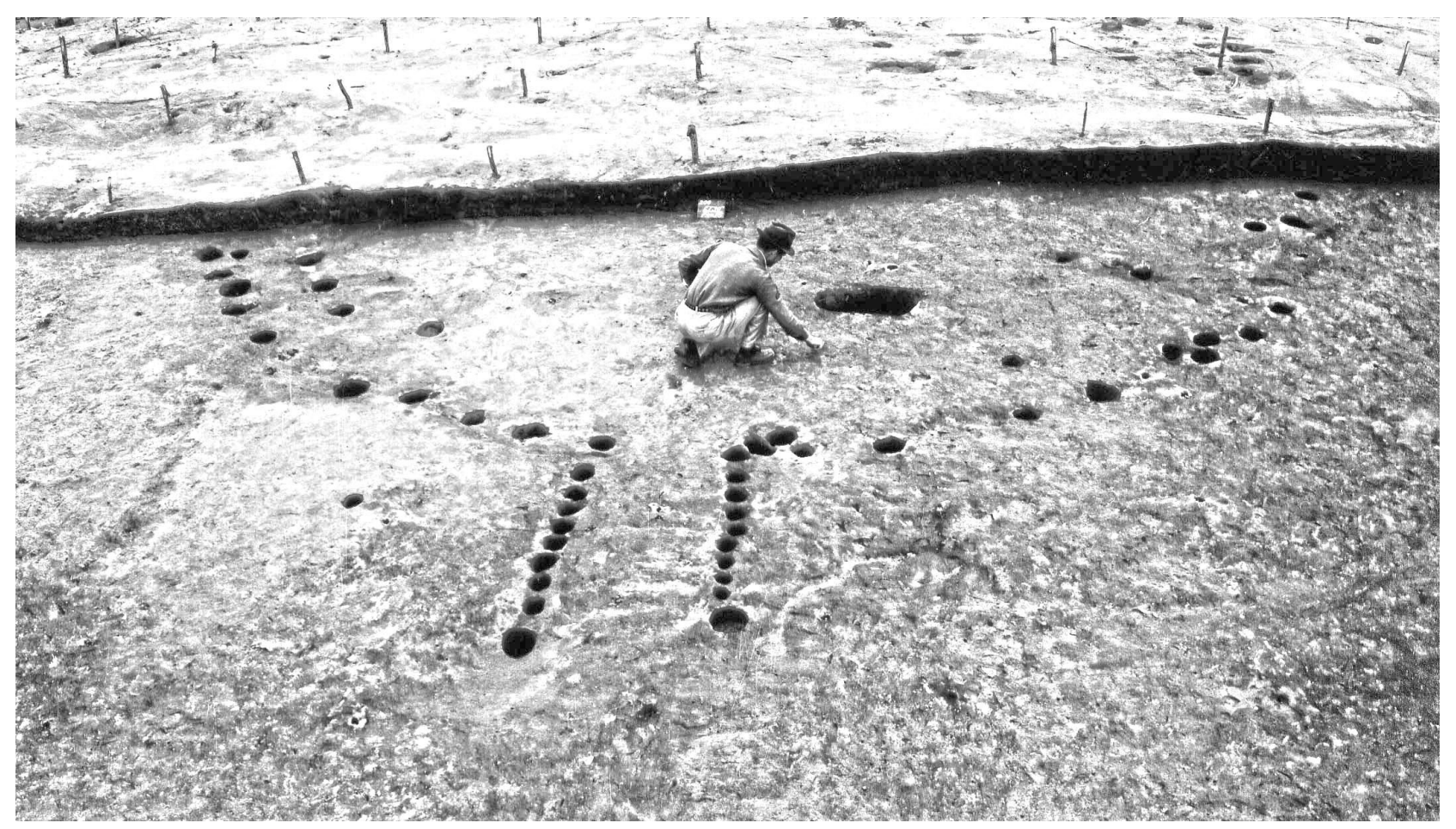

Figure 21. Southern portion of Feature 15 and its extended entranceway. Image 41BW3-128, Texas Archeological Research Laboratory, The University of Texas.

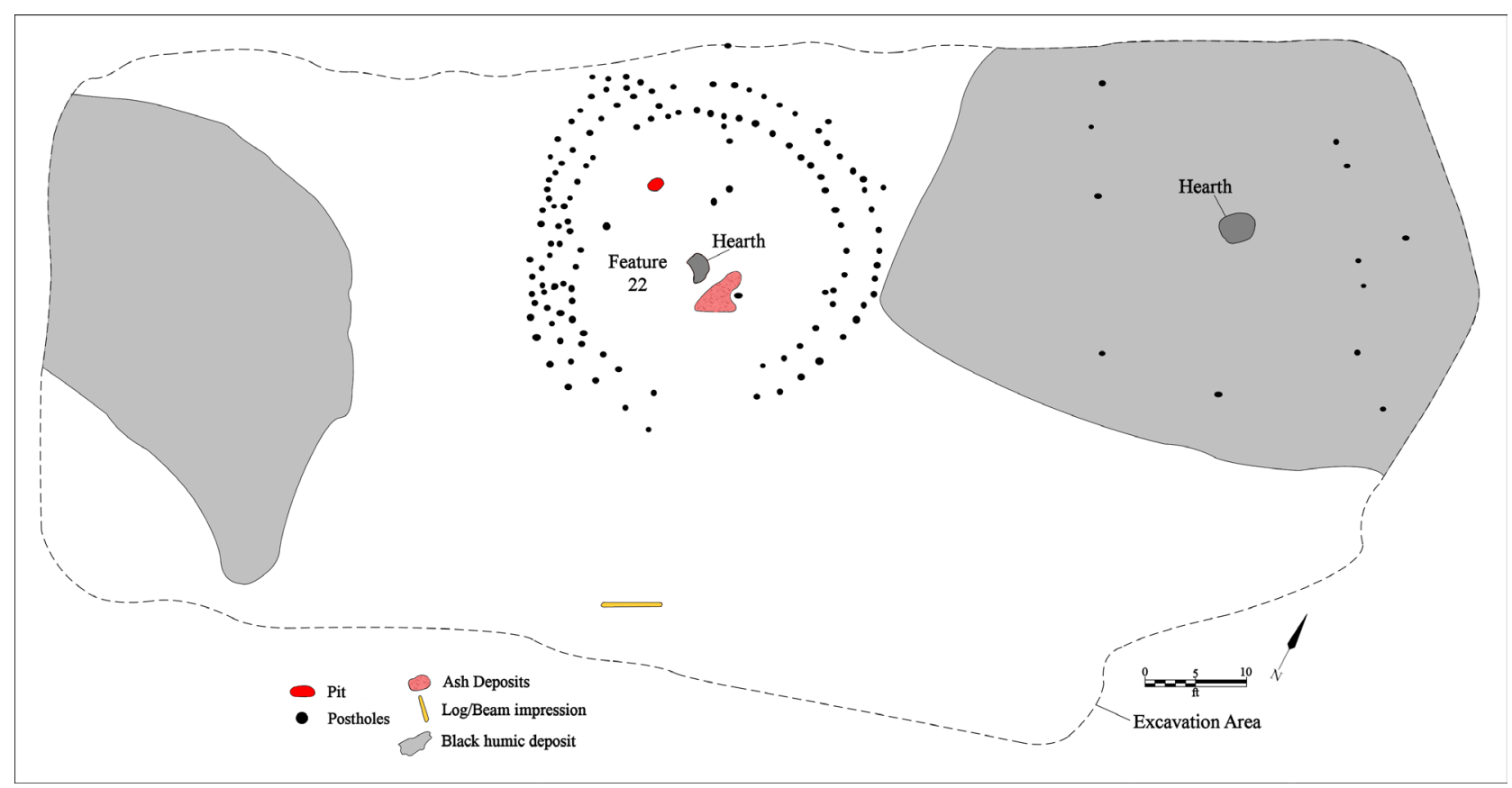

Figure 22 Plan map of Zone G structure and other features. 


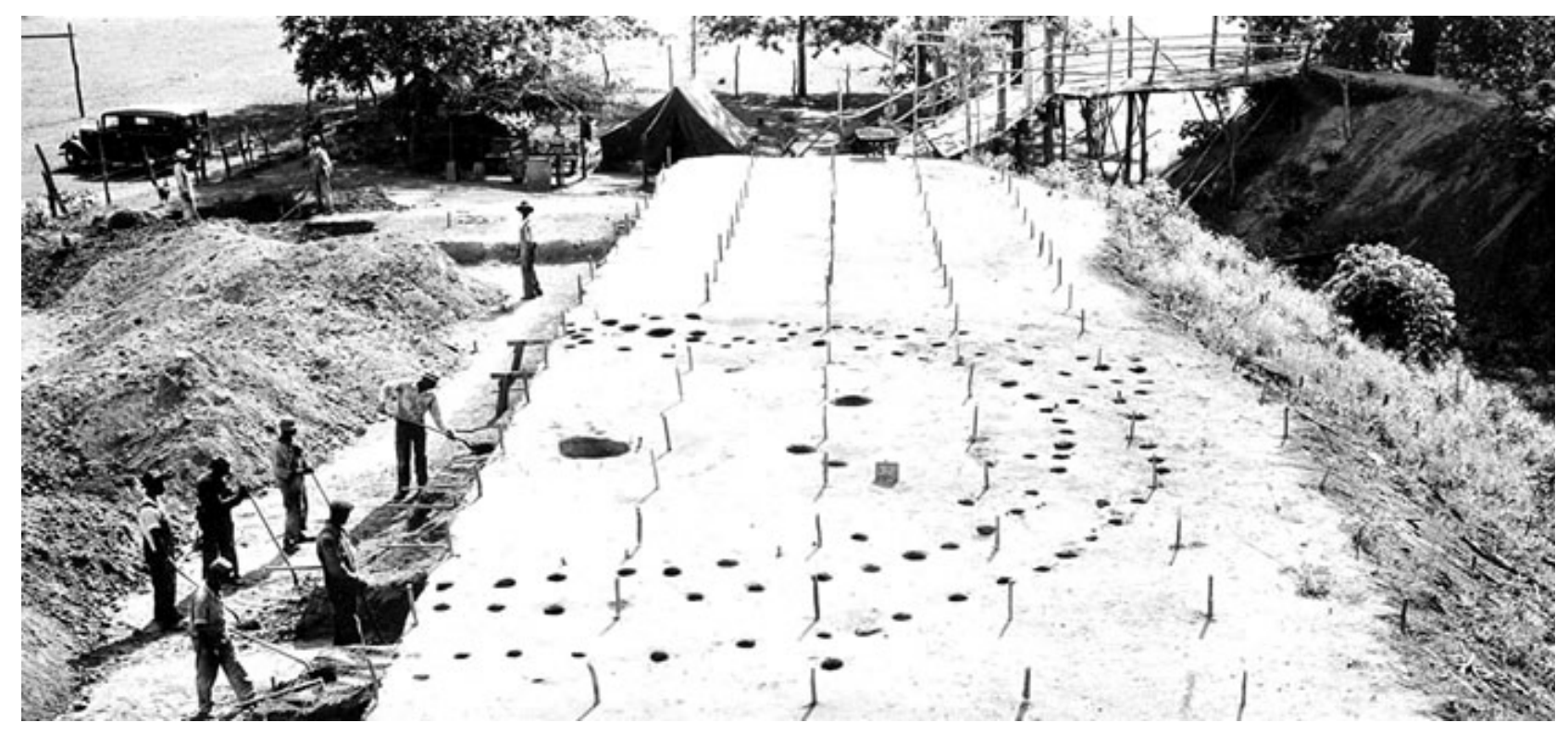

Figure 23. Northern half of Feature 22. Image 41BW3-236, Texas Archeological Research Laboratory, The University of Texas at Austin.

Feature 22 was built upon a brown sandy loam in proximity to the western black humic deposit (TARL n.d:264, 273). The easternmost such area has a single large hearth and two widely-spaced linear rows of scattered post holes around the hearth (about $15 \mathrm{~cm}$ in depth), suggesting there may have been a rectangular platform constructed on the eastern side of the platform mound.

A single cedar log beam is present in Zone G, but well removed from Feature 22 (see Figure 22). The beam is $1.8 \mathrm{~m}$ in length and an average of $12 \mathrm{~cm}$ in width (TARL n.d.:265).

\section{Floor H}

The initial platform mound zone with structures, Zone $\mathrm{H}$, has three different structures arranged from east to west across the hard-packed mound platform (Figure 24). There are also apparent midden deposits (i.e., black humic deposits) by two of the structures (Features 18 and 19/20) as well as ash deposits and several extramural hearths and various large pit and small pit features; none of the three structures has a central hearth, although there is an apparent hearth near the north wall of Feature 16.

A light red clay comprised much of Zone $\mathrm{H}$, or at least the areas with two of the mound structures, along with midden deposits, and sandy loam along the margins of the mound platform. There were small areas of blue clay at the western end of Zone H (TARL n.d.:285).

Beginning on the western side of the mound platform is Feature 16, a circular structure $7.32 \mathrm{~m}$ in diameter with a $3 \mathrm{~m}$ long extended entranceway facing to the southeast (see Figure 24). It was built on a brown sandy loam deposit (TARL n.d.:325). The extended entranceway to the structure appears to be blocked by a semi-circular arc or partition of post holes (Feature 17) (Figure 25), although the WPA archaeologist suggested that Feature 16 "had been superimposed on the remains of" Feature 17 (TARL n.d.:326, 333). There is a hearth with an ash deposit near the northern wall of the structure, and another similar feature (in a $36 \mathrm{~cm}$ deep basin) just outside the north wall. Further north of Feature 16 is a roughly rectangular cluster of post holes that may mark a ramada or arbor. 


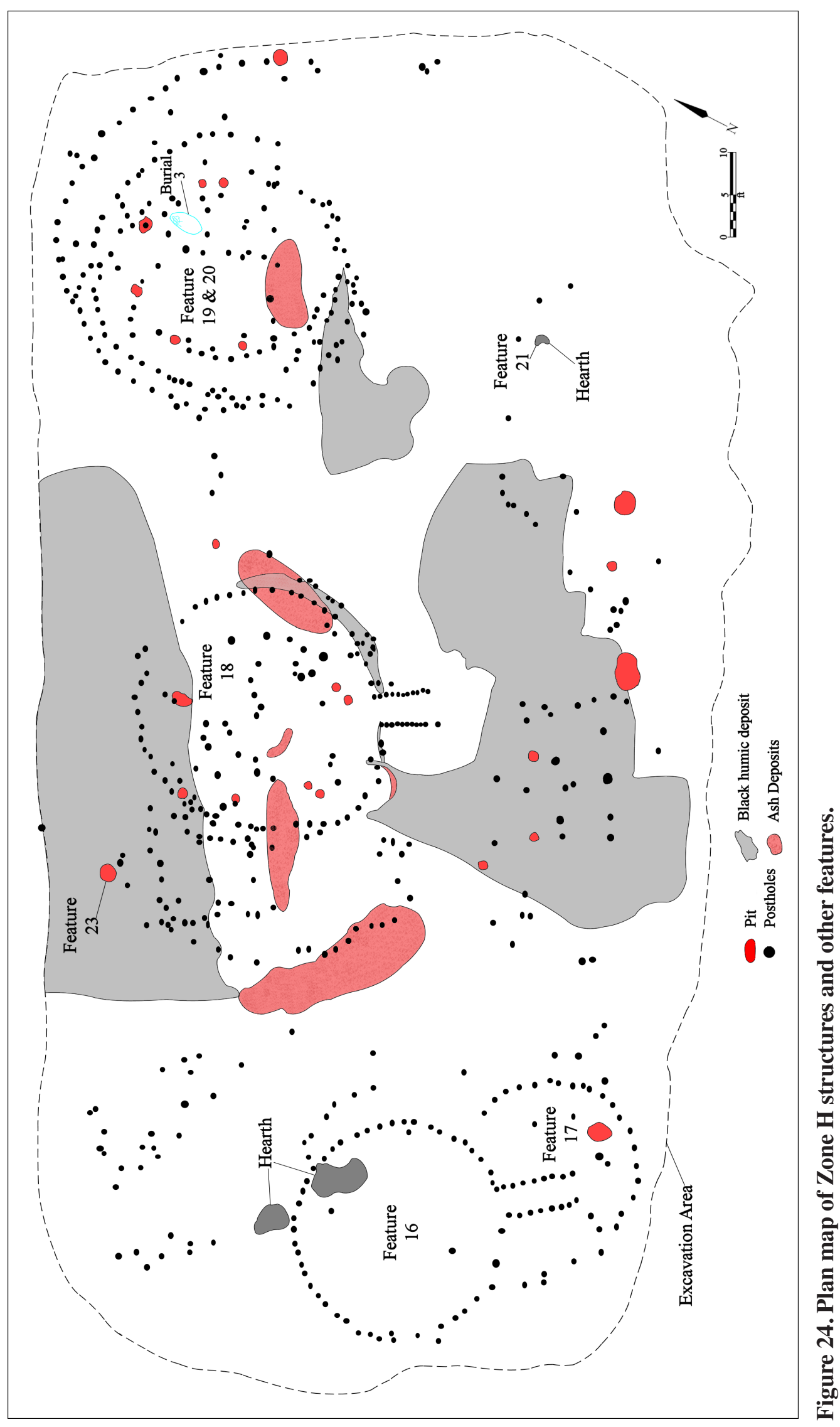




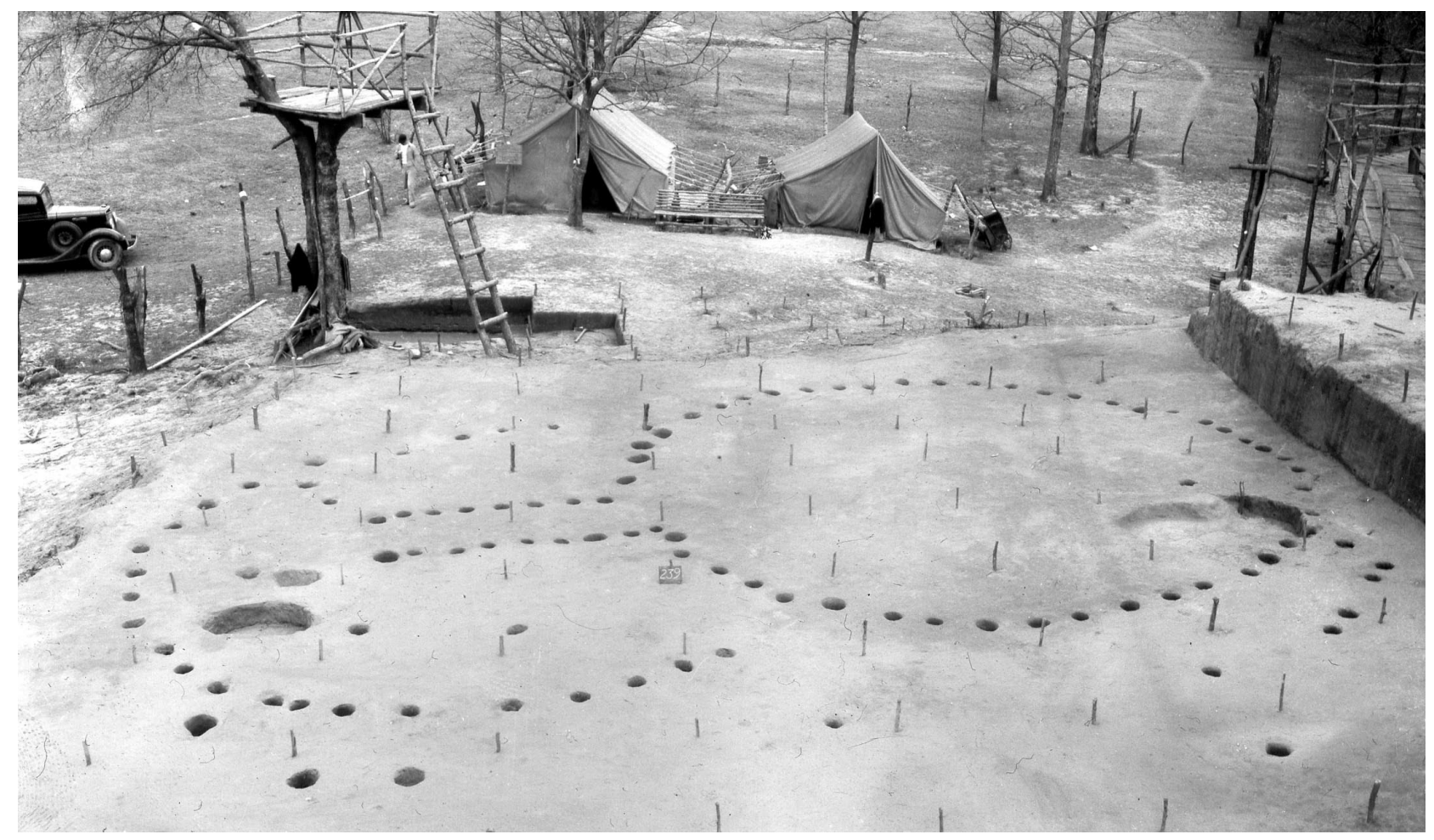

Figure 25. Looking west at Features 16 and 17 in Zone H. Image 41BW3-163, Texas Archeological Research Laboratory, The University of Texas at Austin.

The structure in the center of the mound platform, Feature 18, also has an extended entranceway oriented to the southeast; the entranceway is ca. $1.8 \mathrm{~m}$ in length (see Figure 24). The structure was built atop a small clay mound deposit (TARL n.d.:286, 335). There are several small pits within the structure as well as a number of post holes that probably represent the footing for racks and storage benches inside the structure. Ash deposits lie along and outside both east and west walls, suggesting this structure had been burned down. Just outside the west wall of Feature 18 is a ca. $4.2 \times 3.4 \mathrm{~m}$ rectangular area of post holes that may be an elevated work platform, arbor, or ramada (see Figure 24). There are "black humic deposits" or probable midden deposits to the immediate north and south (there are both small and large pits in both areas) of Feature 18; the northern such deposits overlaps with the Feature 18 post hole pattern, suggesting it accumulated atop the structure, and thus these deposits may be associated with one or both of the other structures in Zone $\mathrm{H}$.

The easternmost structure in Zone H, Feature 19/20, is represented by a confusing array of post holes (see Figure 24). They suggest a circular structure with double walls of posts and an interior partition on the western side of the structure. There is a gap of post holes along the eastern wall that may represent an entrance. Within the structure are several pits as well as a substantial ash deposit (but only $3 \mathrm{~cm}$ thick, TARL n.d.:355) outside the area of the suggested interior partition (see Figure 24). A small "black humic deposit" is present alongside the southern wall of the structure. Finally, Burial 3 is associated with Feature 19/20.

Feature 23, a small pit northwest of Feature 18 (see Figure 24), contains the buried remains of an adult male bald eagle (Haliaeetus leucocephalus) (TARL n.d.289, 361-362), a unique discovery on an East Texas Caddo site. The bald eagle remains lay folded at the bottom of the pit, ca. $33 \mathrm{~cm}$ below the surface of Zone H. Bald eagle remains were found in two burials at the late $17^{\text {th }}$-early $18^{\text {th }}$ century Cedar 
Grove site (3LA97) on the Red River, including a mostly complete bald eagle in Burial 2 (Trubowitz 1984:Figure 10-2) and a humerus fragment in Burial 3 (Styles and Purdue 1984:218). Webb (1959:36) noted the "articulated skeleton of a large bird, hawk or eagle" on the House 3 floor in Bossier phase (ca. A.D. 1200-1500) contexts at the Belcher Mound site (16CD13). It has subsequently been identified as a golden eagle (Jeffrey S. Girard, December 2013 personal communication).

The distribution of ceramic sherds in Zone $\mathrm{H}$ indicates that broken vessels were discarded most frequently outside of the structures, rather than in them. The sherds were distributed primarily well north and northeast of Feature 16 and not far west of Feature 18, and between Feature 18 and Features 19/20 (TARL n.d.:548). Sherds, however, were also common within Features 19/20, suggesting re-use of the area while several overlapping structures were built on the northern and eastern part of the mound (see Figure 24).

\section{Associated Material Culture Remains}

A number of reconstructed vessels and vessel sections were found in the mound structure zones, but they were not apparently associated with burials. This included a flaring rim engraved bowl $(9.5 \mathrm{~cm}$ in height and $14.2 \mathrm{~cm}$ in diameter) of the Avery Engraved type (Figure 26a-b; see also Webb [1959:Figure 119] for similar flaring rim vessels from the contemporaneous Belcher site) resting on the floor of Feature 12 in Zone D (TARL n.d.:190) as well as a section of a large plain burnished vessel at least $10.1 \mathrm{~cm}$ in height and $20.7 \mathrm{~cm}$ in diameter. A large McKinney Plain jar with a roughened rim and vertical rows of appliqued nodes on the rim was reconstructed from sherds in both Zones D and E, suggesting little separation in age between the accumulation of these two mound structure zones. An inverted rim Simms Engraved carinated bowl was recovered in Feature 14 in Zone E (see Figure 37b, below). In Zone F was a small and plain carinated bowl $(4.3 \mathrm{~cm}$ in height and $8.1 \mathrm{~cm}$ in diameter) (Figure 27a-b), an inverted rim Simms Engraved carinated bowl (7.7 cm in height and $16.8 \mathrm{~cm}$ in diameter) (Figure 27c-d), and a medium-sized Karnack Brushed-Incised, var. Karnack jar $(16.3 \mathrm{~cm}$ in height and $11.3 \mathrm{~cm}$ in diameter) (Figure 27e-f). Finally, from the excavations of Feature 22 in Zone G, a small jar decorated with two rows of diagonal incised lines was recovered and reconstructed (Figure $27 \mathrm{~g}$ ), along with a reconstructed plain bowl with a notched lip (Figure 27h).
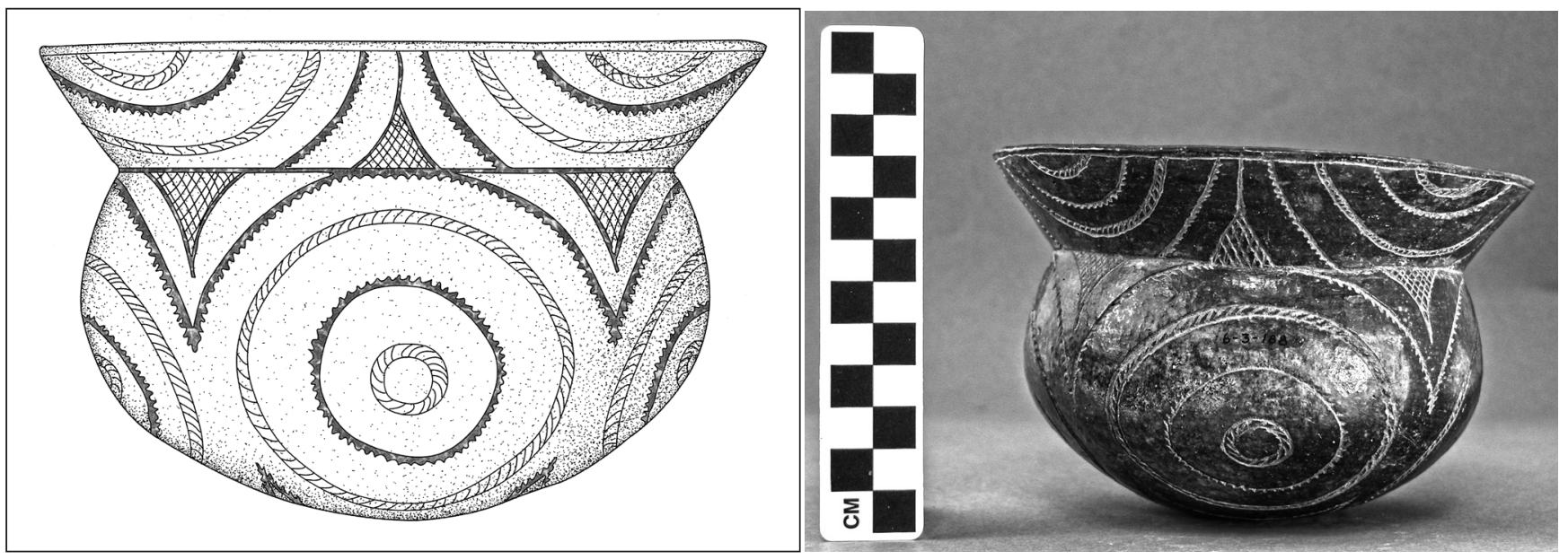

Figure 26. Black Avery Engraved flaring rim bowl from Feature 12 in Zone D: a, photo; b, redrawn from Laughlin (1940). Photograph courtesy of TARL. 

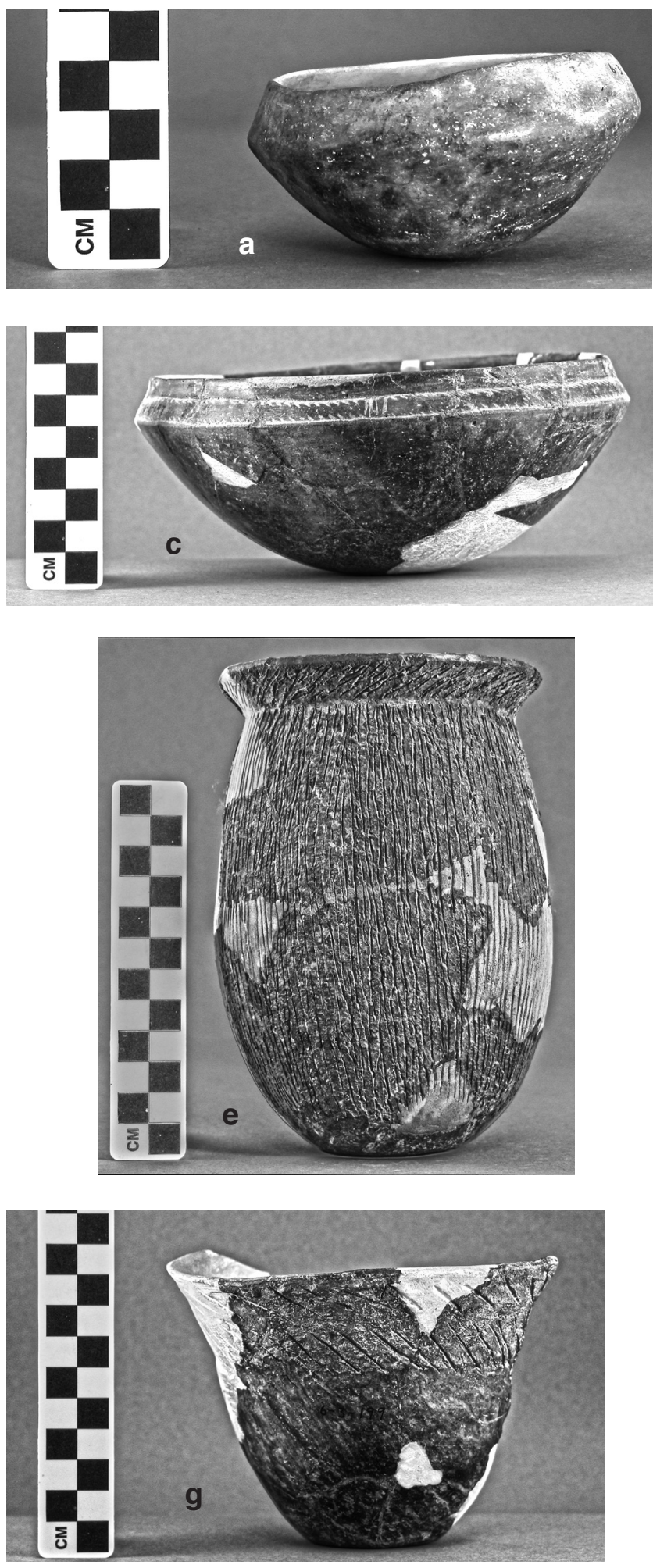

Figure 27. Vessels from Zone F, G, and H: a-b, plain carinated bowl; c-d, Simms Engraved carinated bowl; e-f, Karnack Brushed-Incised jar; g, incised jar; h, lip notched bowl; i, Barkman Engraved carinated bowl; b, d, and f redrawn from Laughlin (1940). Photographs courtesy of TARL.
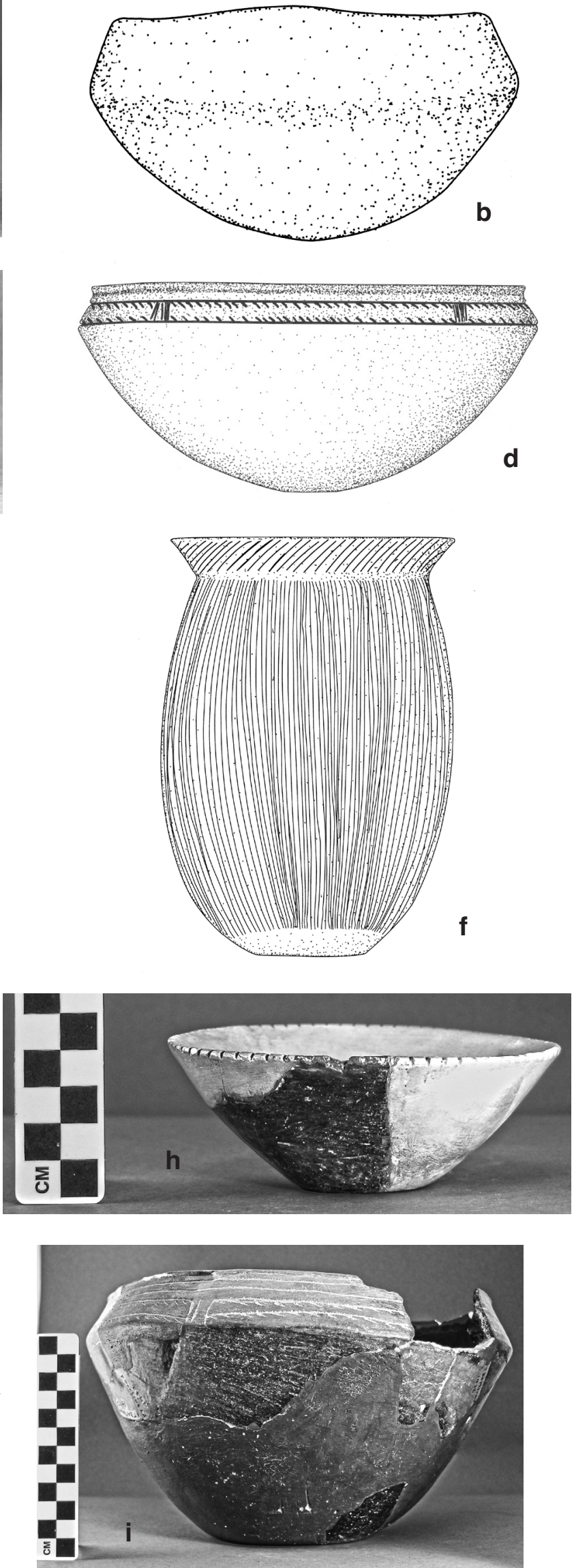
Sections of a Barkman Engraved carinated bowl came from a pit feature that apparently originated in Zone H (see Figure 27i); the context was described as "under Phase H." A single shell-tempered red-on buff painted body sherd from a bottle was also recovered in Zone H. This sherd is from a vessel of nonlocal provenance, likely from a Lower Mississippi Valley or central Arkansas River basin group. Several other shell-tempered rim sherds from Bowie Engraved bowls (see Suhm and Jelks 1962:17 and Plate 9) from the lower zones in the platform mound have a red slip on both vessel surfaces, and an interior thickened rim with an engraved element. These elements include narrow zones with short hatched lines (Zones F and G) and a narrow zone with hatched triangles (Zones E and F). These shell-tempered sherds are from McCurtain phase vessels made by Caddo potters on the mid-Red River (e.g., Suhm and Jelks 1962:17).

In addition to the ceramic vessels and vessel sections from various mound structure zones, there is a large sample of ceramic sherds $(n=16,841)$ from the different mound zones (see Table 1). Based on Laughlin's (1940:58-66) analysis, this includes sherds with the following decorative elements: appliqued $(n=612)$, brushed $(n=768)$, incised $(n=2266)$, tool, fingernail, and cane punctated $(n=587)$, neck banded $(n=120)$, roughened (cf. McKinney Plain) $(n=391)$, engraved $(n=501)$, red-slipped $(n=503)$, and trailed $(n=450)$. These proportions indicate that approximately $78 \%$ of the sherds are from utility wares and the remainder are from fine wares (i.e., engraved, red-slipped, and trailed). These proportions are considerably different from the decorated sherd assemblage in Village Plot 1 (see Part II of this volume), where $53 \%$ of the sherds are from fine wares. There was one engraved ceramic duck effigy head in the assemblage, from Zone B (Figure 28).

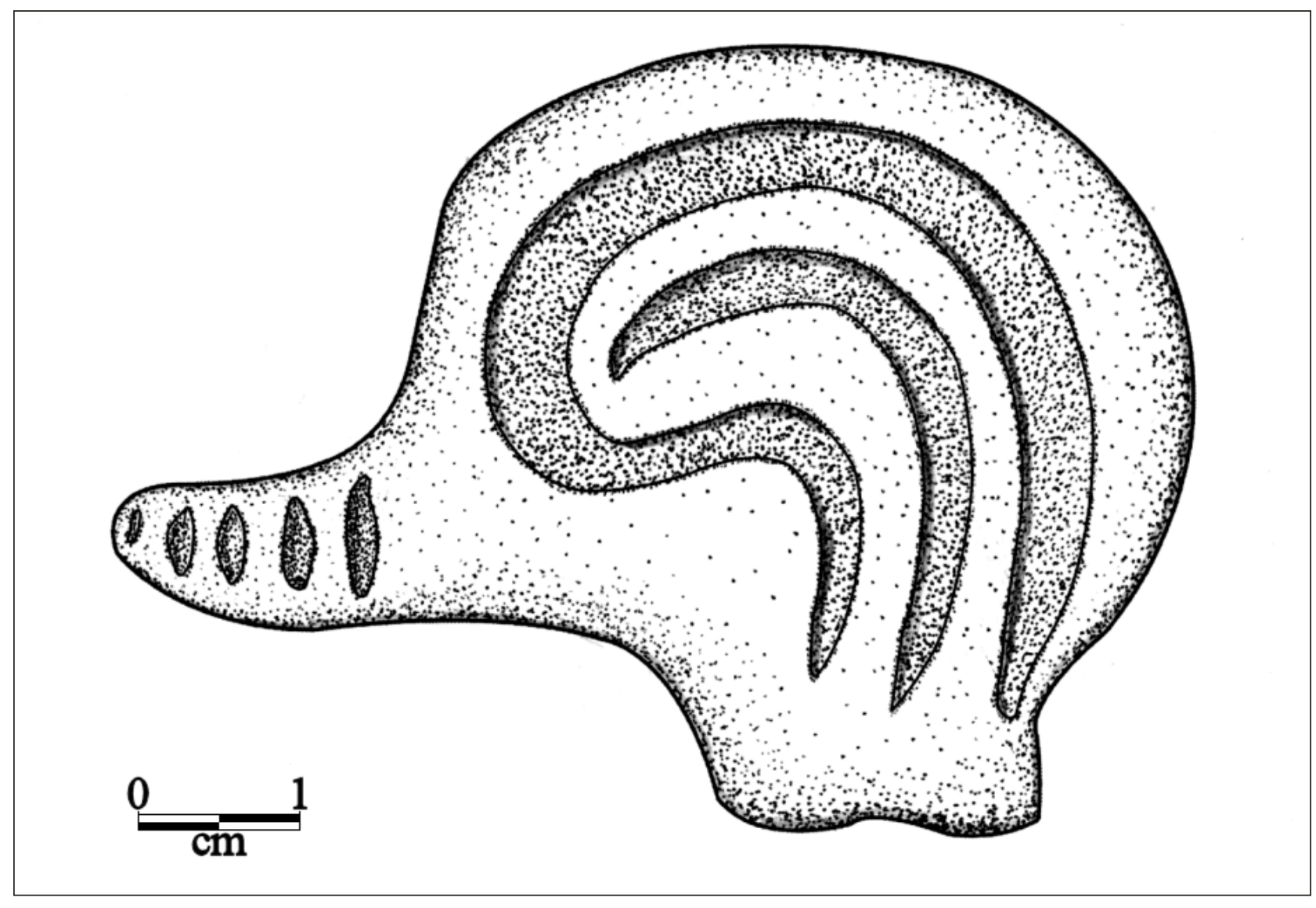

Figure 28. Ceramic duck effigy head sherd from Zone B in the platform mound at the Hatchel site. Redrawn from Laughlin (1940). 
A total of 379 of the decorated sherds had either a red $(46.5 \%)$ or white $(53.5 \%)$ pigment rubbed in the engraved lines. Sherds with a red pigment were recovered only in the uppermost mound structure zones (Zones A-C), but both red and white pigments were found in the other zones (Laughlin 1940:57). Masses of white and green clay pigment came from Zones $\mathrm{E}$ and $\mathrm{G}$.

There is also a wide variety of other material culture remains recovered in the mound deposits. This includes six clay elbow pipes, one with a double stem (Figure 29c), from zones G-I (Figure 29e) and 41 pipe stem and bowl sherds; these were found in zones C-D, F-K (see Laughlin 1940).

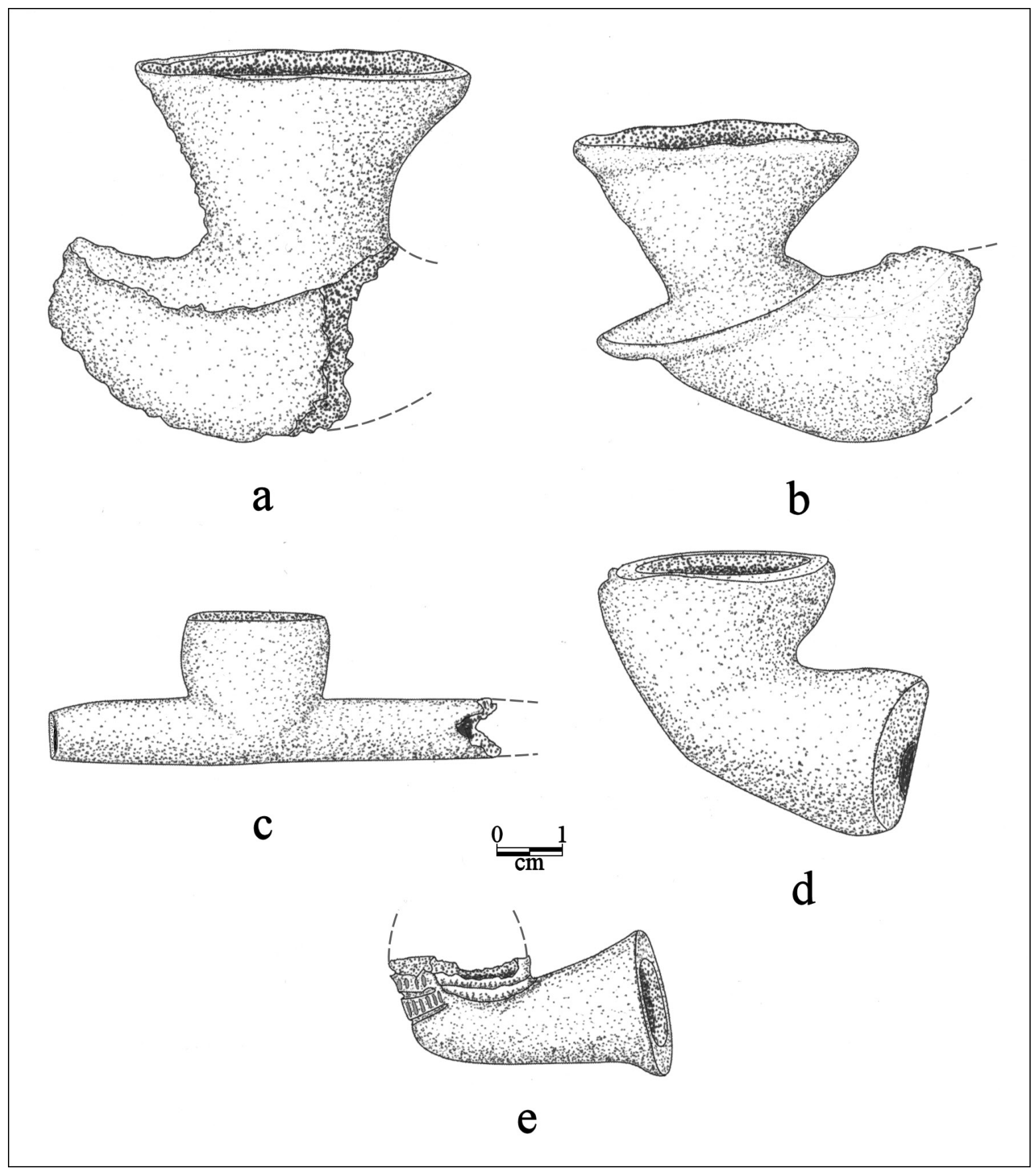

Figure 29. Clay elbow pipes in the platform mound at the Hatchel site: a-d, Zone H; e, Zone I. Redrawn from Laughlin (1940). 
Chipped stone tools were not apparently abundant in any of the structure zones, except Zone $\mathrm{H}$ ( $\mathrm{n}=31$ tools). Most of the chipped stone tools are arrow points $(n=56)$. The stemmed arrow points $(n=26)$ are primarily of the Bassett type (58\%), and they are mainly in the lower and earlier mound zones (81\% from zones G-K) (Figure 30a-d, g-h). The others are straight-stemmed and bulbous-stemmed forms (Figure 30e-f) similar to those from Belcher phase contexts at the Belcher site (Webb 1959:Figure 125) and the McLelland site (Kelley 2012:423). The other arrow points are triangular Maud points with concave bases $(n=21)$ (Figure 31). These points are primarily $(71 \%)$ from zones A-F, indicating they are a later point form. This stratigraphic change in the proportions of either Bassett or Maud points in the mound zonesas has also been detected in the seriation of Late Caddo period, Titus phase burials in the Big Cypress Creek basin (Perttula 1992:247-249) - suggests that the lower mound zones likely date from ca. A.D. 1450-1550, while the upper mound zones likely date after ca. A.D. 1550.
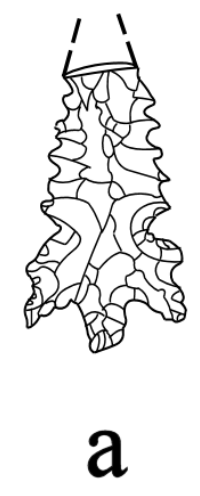

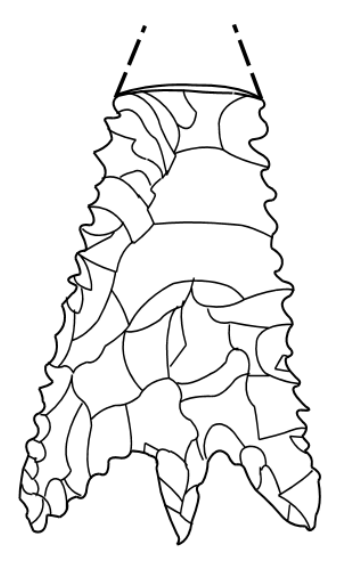

b
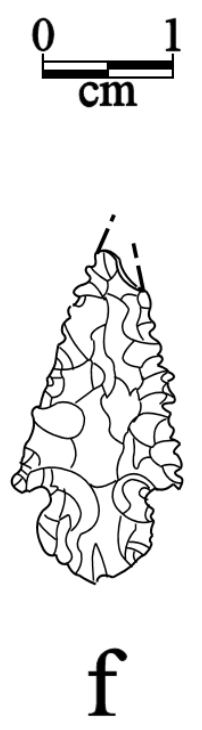

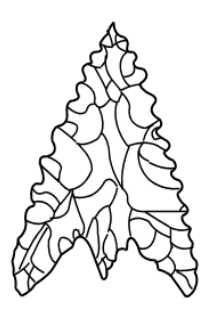

C

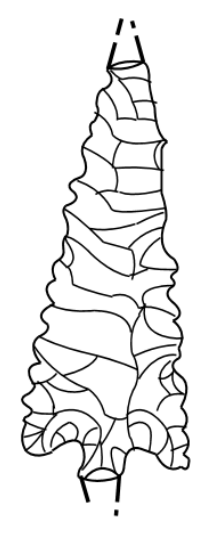

$\mathrm{g}$
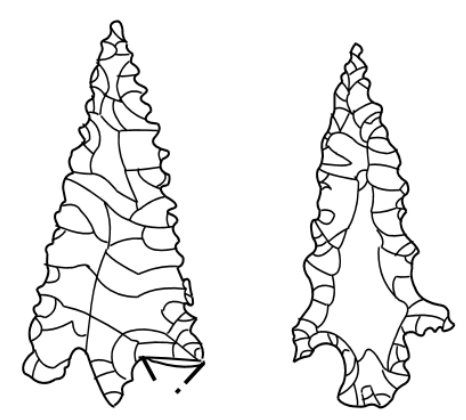

e

Figure 30. Stemmed arrow points from the platform mound at the Hatchel site: a, Zone F; b-f, Zone H; g, Zone I; h, Zone K. Redrawn from Laughlin (1940). 


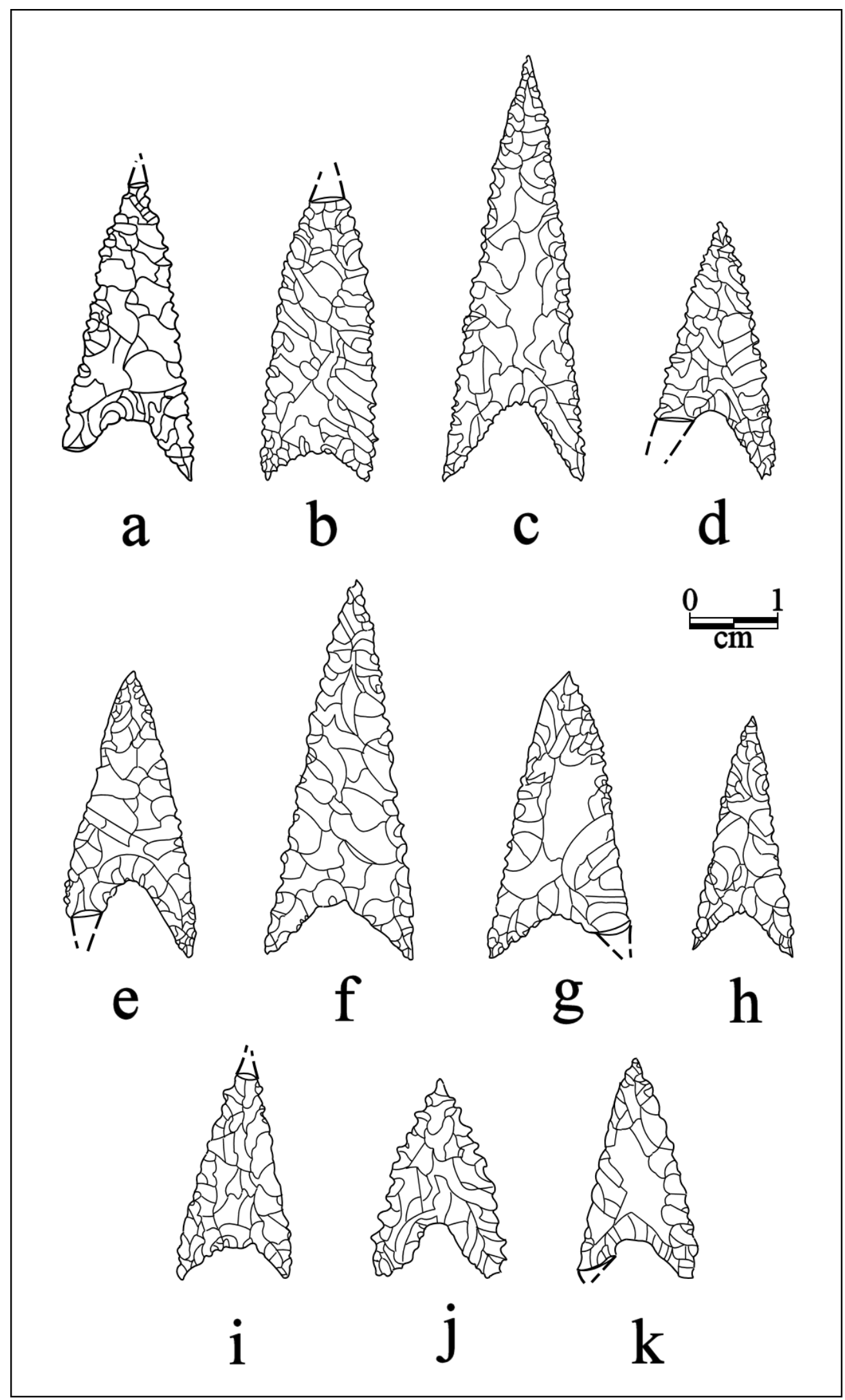

Figure 31. Maud arrow points from the platform mound at the Hatchel site: a-b, Zone B; c-d, Zone C; e, Zone D; f-h, Zone E; i, Zone F; j-k, Zone H. Redrawn from Laughlin (1940). 
The ground stone tools from the mound zones are represented by celts $(n=24)$, most from Zone H; abraders $(n=6)$, manos, metates, and slabs $(n=14)$, most from Zone $\mathrm{G}$, and a stone pestle in Zone E. Most of the celts are rectangular in shape, with relatively straight sides, and well-defined bit edges (Figures 32a-f and 33c); there are petaloid celts, perhaps an earlier style of celt, from Zones H and I (Figure 33ab). Other artifacts of note include a single turquoise bead from Zone H (TARL n.d.:546), a Olivella sp. shell bead from Zone $\mathrm{H}$, a conch shell bead from Zone E, quartz crystals $(\mathrm{n}=4)$ from Zones F-H (Figure 34a-b), and two perforated strips of copper from Zone H (Figure 35).

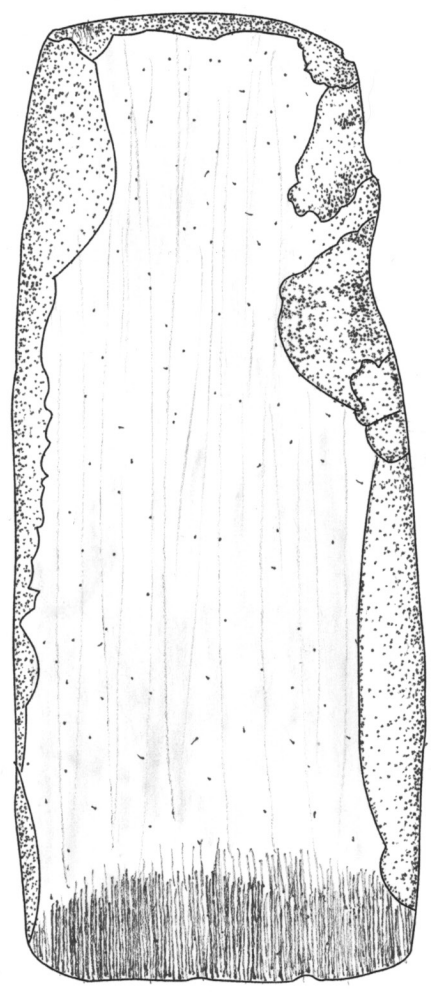

a

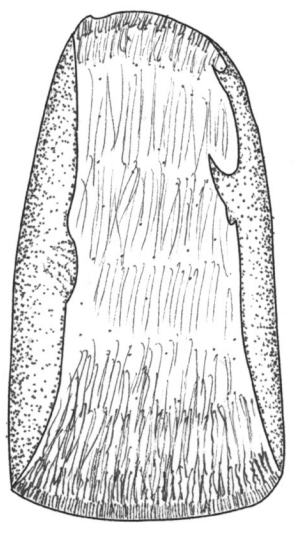

d

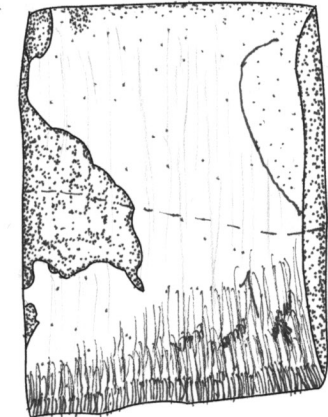

b

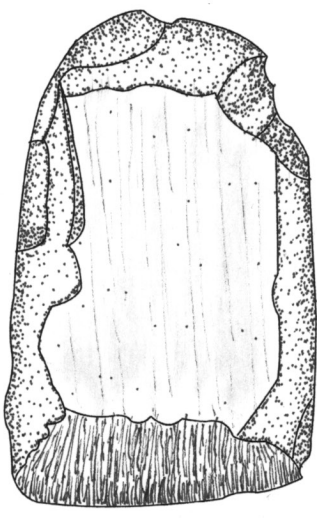

C

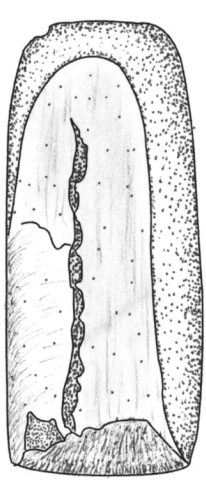

e
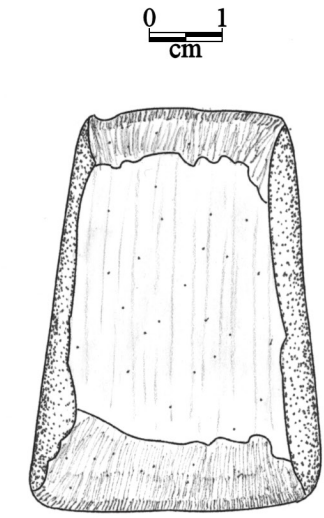

f

Figure 32. Celts from the platform mound at the Hatchel site: a, Zone D; b, Zone F; c, Zone G; d, Zone H; e-f, Zone I. Redrawn from Laughlin (1940). 


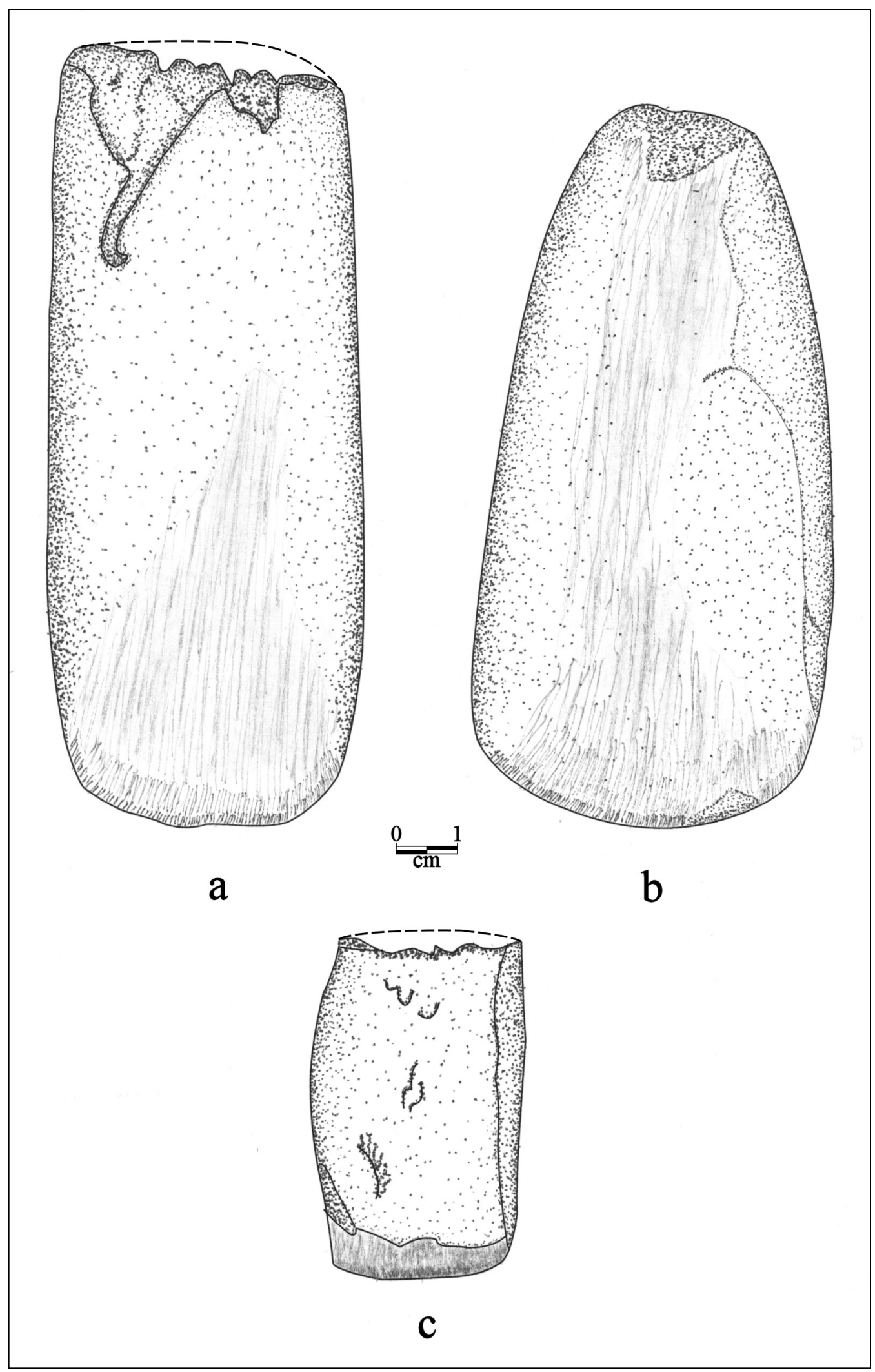

Figure 33. Celts from the lower mound zones and Zone $K$ under the mound: a, Zone H; b, Zone I; c, Zone K. Redrawn from Laughlin (1940). 


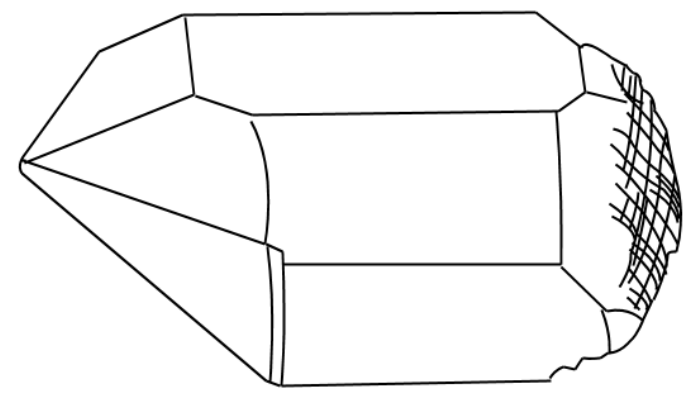

a

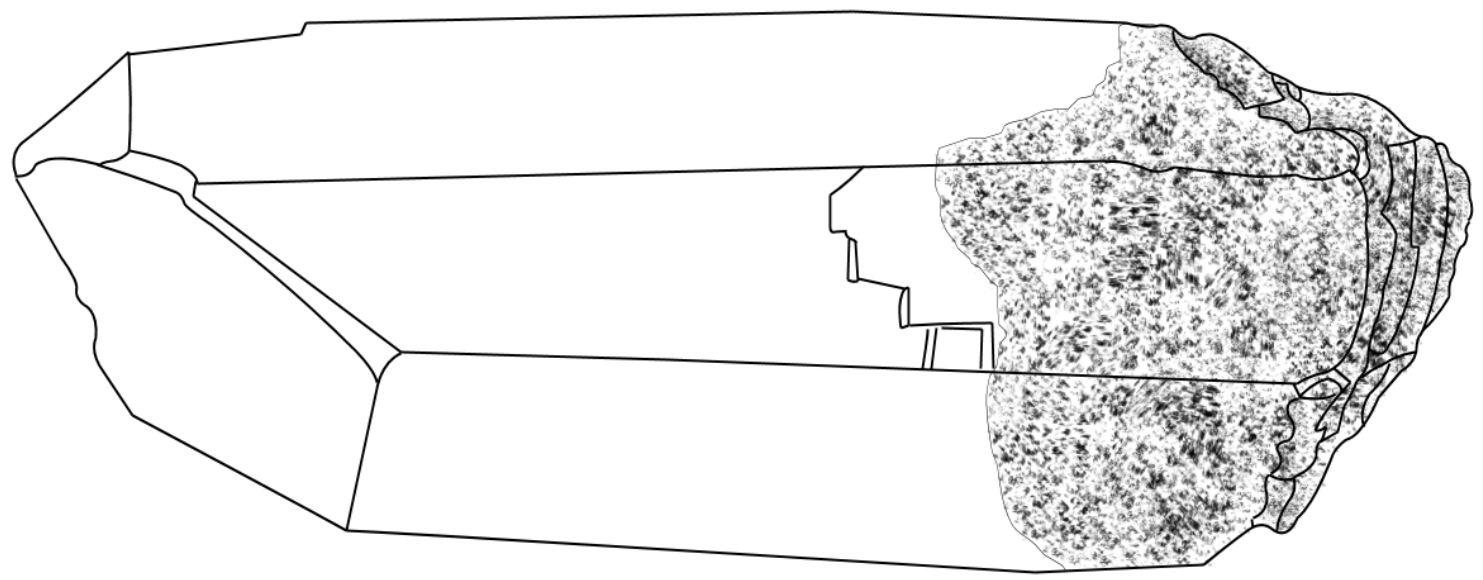

b

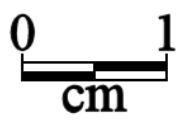

Figure 34. Quartz crystals from the platform mound at the Hatchel site: a, Zone F; b, Zone H. Redrawn from Laughlin (1940).

Animal bone and teeth tools and ornaments $(n=45)$ are found in many of the structure zones in the platform mound, particularly Zone F (20\%) and Zone H (47\%). These include bone awls, hairpins and hair ornaments (Figure 36a-b), needles, a serrated deer rib, deer bone and antler flakers and other antler tools $(n=18)$, as well as five bone beads (Figure 36i), a bone ear spool (Figure 36d), and bear $(n=1)$ and perforated dog $(n=5)$ teeth (Figures 36c, e-h); the teeth are found exclusively in Zones F-H.

There are also mussel shell tools in the various mound platform deposits. This includes mussel shell hoes $(n=10)$ from Zones $\mathrm{G}-\mathrm{K}$, nine small perforated mussel shells from Zones $\mathrm{F}$ and $\mathrm{H}$, and one serrated mussel shell tool from Zone G (TARL n.d.:547). 


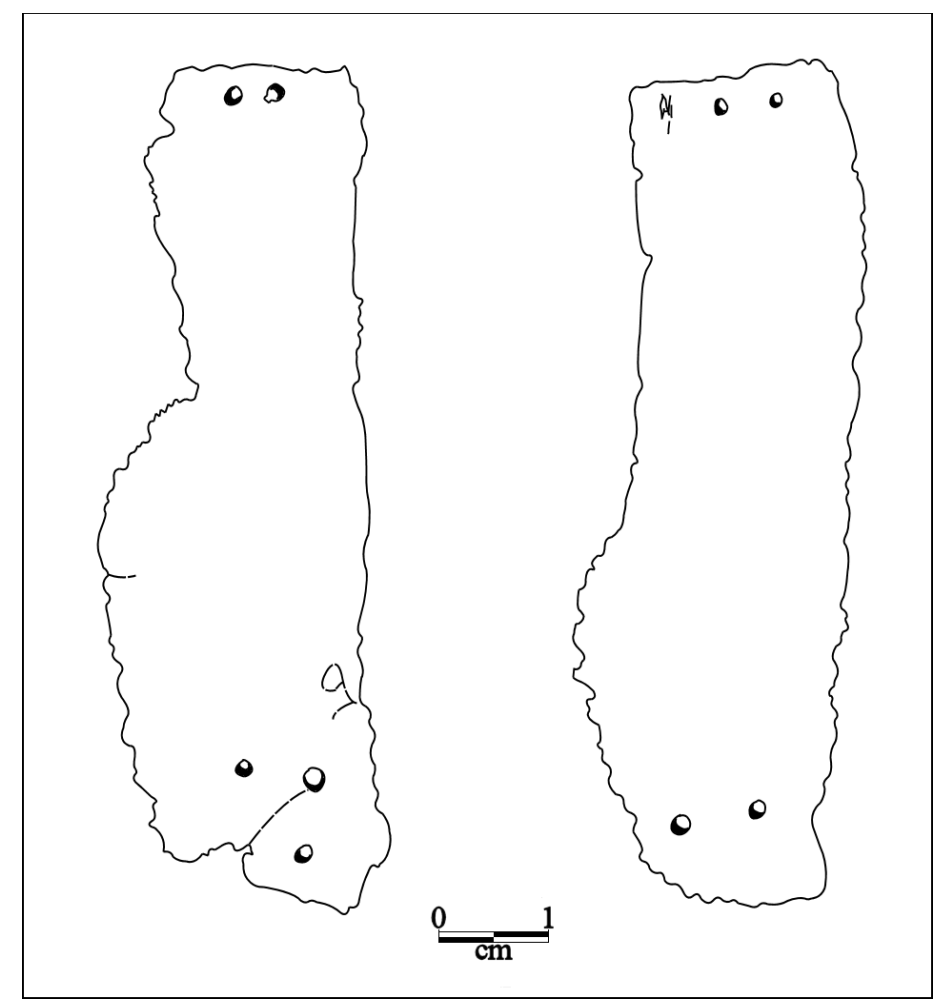

\section{Figure 35. Perforated copper strips from $Z$ Zone $H$ in the platform mound at the Hatchel site. Redrawn from Laughlin (1940).}

\section{Burials in Zones $E, F$, and $H$}

Three child burials were excavated in the mound structure zone deposits (Lee 1997:Table 1), one each in Zones E, F, and H. Burial 1 in Zone E (see Figure 19) was an infant (8-10 months) of indeterminate sex (Lee 1997:Table 2), represented by skull, femur, vertebrae, ribs, and tibia fragments (TARL n.d.:221). Associated grave goods with the child included two ceramic vessels, a single shell bead, and two bone ornaments. One of the vessels is a Foster Trailed-Incised, var. unassigned jar $(11.8 \mathrm{~cm}$ in height and $12.5 \mathrm{~cm}$ in diameter) (Figure 37c) while the other is an intricately decorated Keno Trailed bowl (7.8 $\mathrm{cm}$ in height and $11.1 \mathrm{~cm}$ in diameter) with a wide flaring rim and a notched lip (Figure 37a).

Burial 2 (Zone F), an adolescent (12-15 years of age) of unknown sex, was buried in an extended supine position (see Figure 20) with the head facing to the northwest (TARL n.d.:259), along with three ceramic vessels and a mussel shell valve that had been placed inside one of the vessels. The burial appears to have been interred "immediately prior to the deliberate covering of this section" of Zone F (TARL n.d.: 239, 260). The vessels include a Barkman Engraved carinated bowl (Figure 38a-b; $8.8 \mathrm{~cm}$ in height and $15.9 \mathrm{~cm}$ in diameter) by the legs, with a white pigment rubbed in the engraved lines, and two Foster Trailed-Incised jars by the head, one a $16^{\text {th }}$ to early $17^{\text {th }}$ century Foster Trailed-Incised, var. Red Lake vessel (14.1 cm in height and $15.2 \mathrm{~cm}$ in diameter) (cf. Schambach and Miller 1984:121 and Figure 11-10) (Figure 38e-f). The other Foster Trailed-Incised, var. unspecified jar is $11.9 \mathrm{~cm}$ in height and 13.3 $\mathrm{cm}$ in diameter; it has appliqued knobs on the body (Figure 38c-d). 


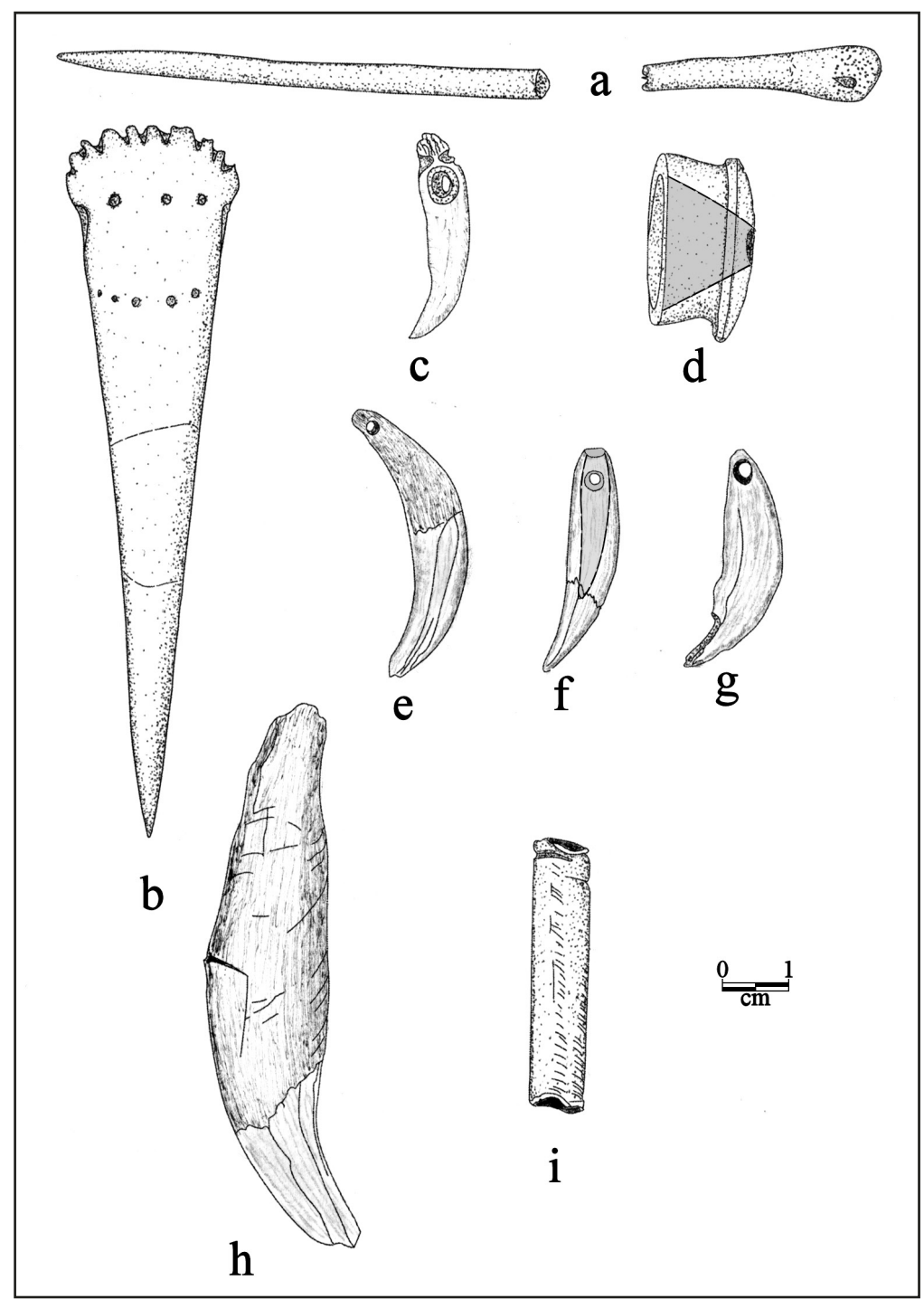

Figure 36. Bone and teeth artifacts from the platform mound at the Hatchel site. Redrawn from Laughlin (1940): a, bone hairpin from Zone $\mathrm{C}$; b, bone hair ornament from Zone $\mathrm{H}$; c, canine tooth pendant from Zone G; d, bone ear spool from Zone G; e, canine tooth pendant from Zone F; f-g, canine tooth pendants from Zone $\mathrm{H}$; $\mathrm{h}$, bear tooth from Zone $\mathrm{H}$; i, bone bead from Zone $\mathrm{F}$.

Burial 3, another infant (9-12 months of age) of unknown sex (Lee 1997:Table 2), was in a $1.1 \times 0.5$ $\mathrm{m}$ pit inside Feature 19/20 that originated in Zone H (see Figure 24). The child was laid in the pit in an extended, supine position, with the head facing south (TARL n.d.:313). This individual also had three ceramic vessels and two mussel shells as associated grave goods (TARL n.d.:307). The ceramic vessels are a medium-sized red-slipped Avery Engraved, var. Bradshaw compound bowl $(15.7 \mathrm{~cm}$ in height and $20.3 \mathrm{~cm}$ in diameter) (see Schambach and Miller 1984:119), a McKinney Plain jar that stands $21.0 \mathrm{~cm}$ in height and $16.4 \mathrm{~cm}$ in diameter and has vertical appliqued strips on the rim and the body, and an appliqued and knobbed rattle bowl $(7.4 \mathrm{~cm}$ in height and $13.9 \mathrm{~cm}$ in diameter) that had four pedestal legs (see Suhm and Jelks 1962:Plate 26c; Webb 1959:Figure 122p) (Figure 39a-f). The compound bowl and the jar were placed in the burial pit atop the rattle bowl (TARL n.d.:314). 

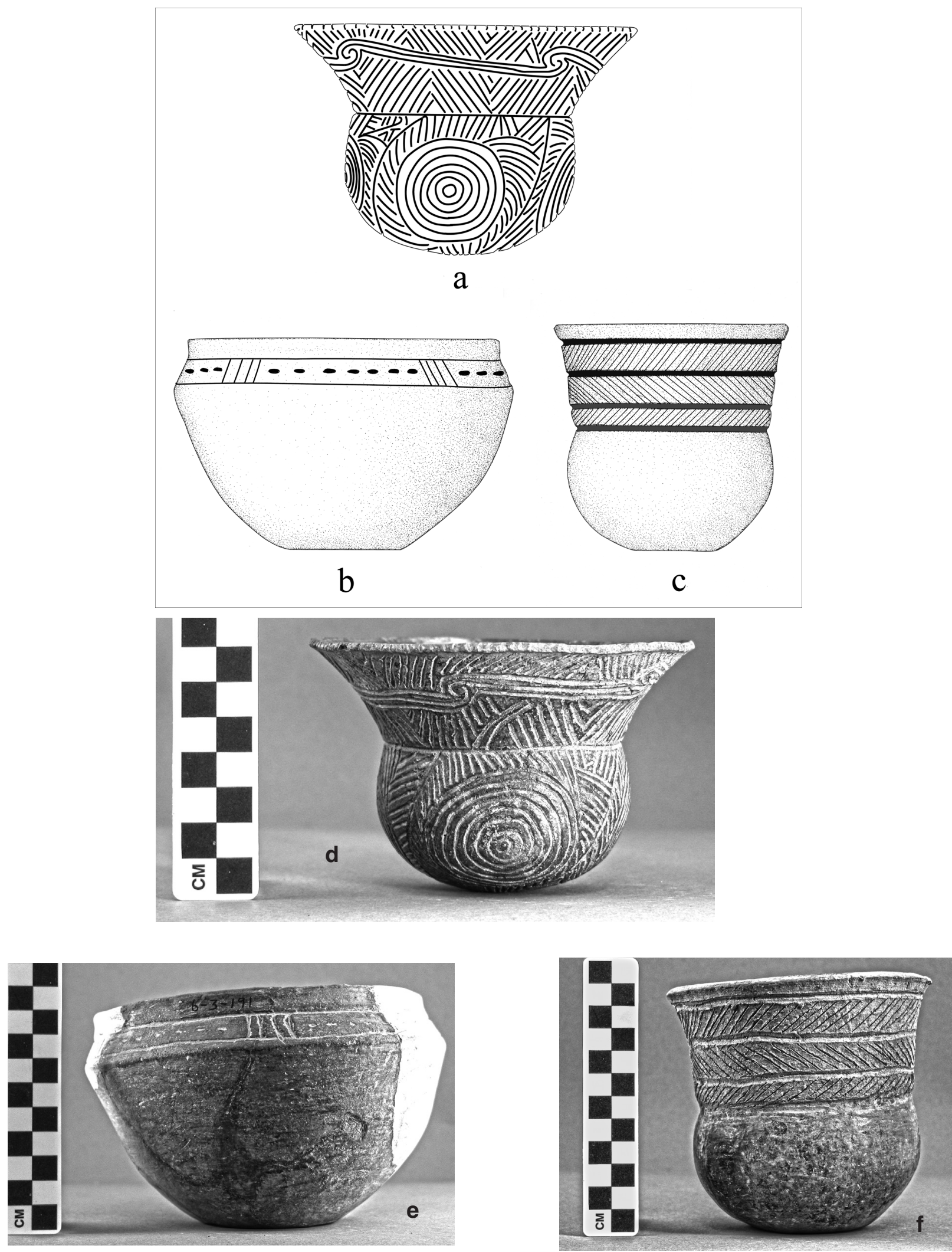

Figure 37. Vessels from Zone E, including Burial 1: a, d, Keno Trailed bowl; b, e, Simms Engraved carinated bowl; c, f, Foster Trailed-Incised, var. unspecified jar. Redrawn from Laughlin (1940). Photographs courtesy of TARL. 


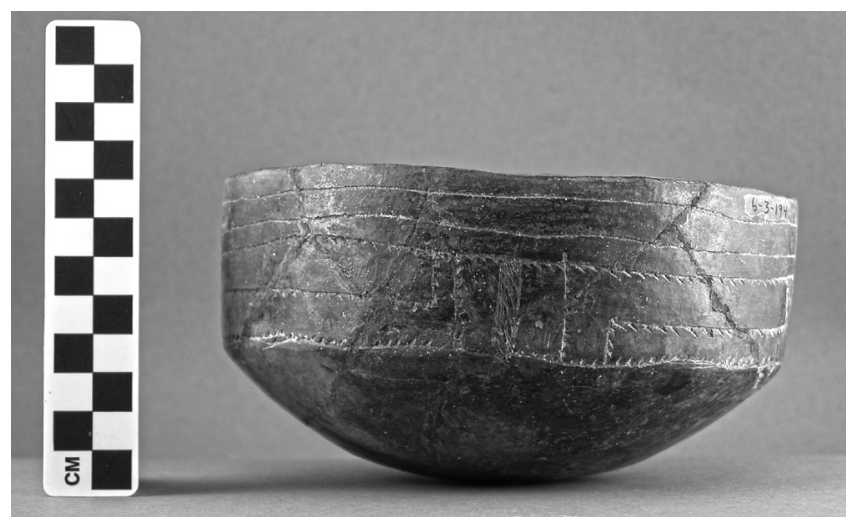

a

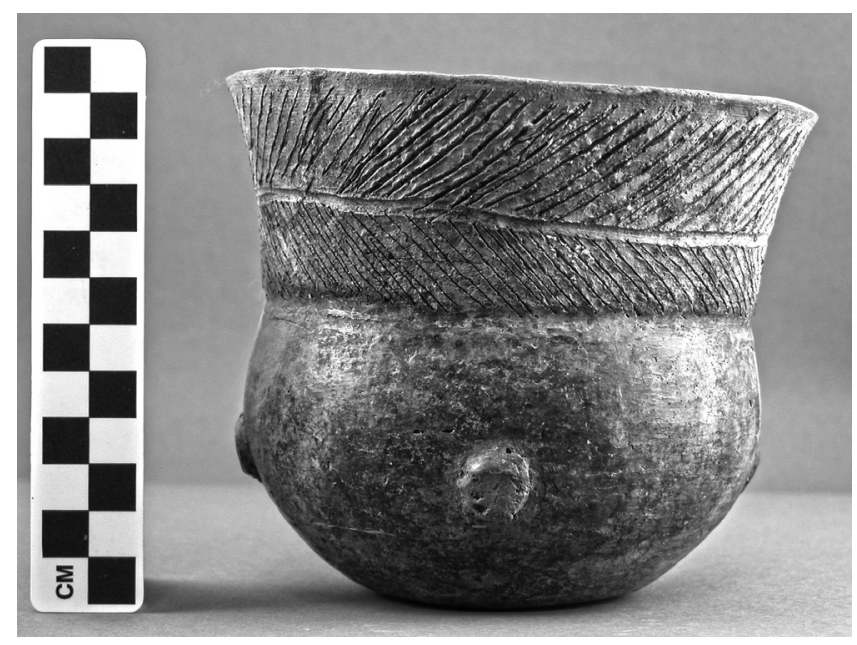

$\mathrm{c}$

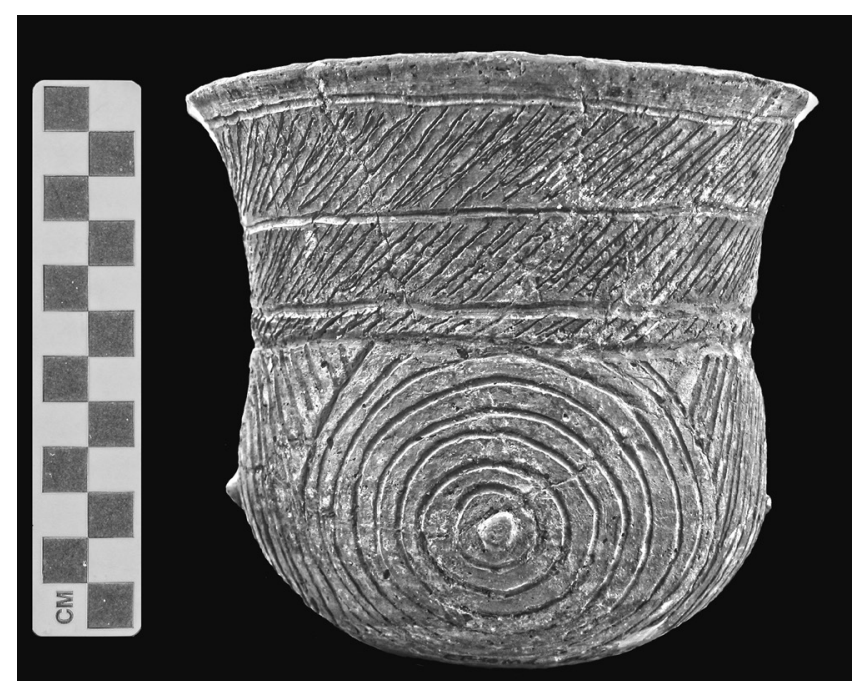

$\mathrm{e}$

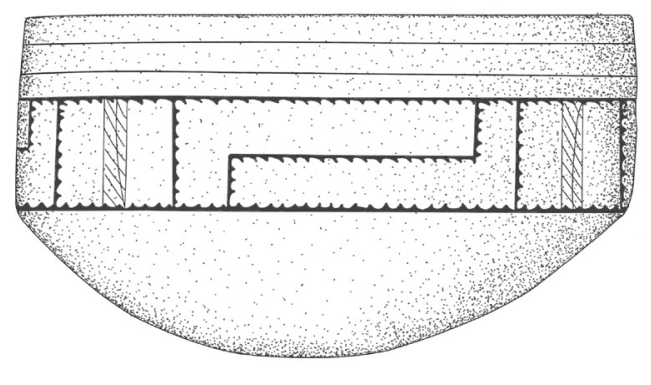

b
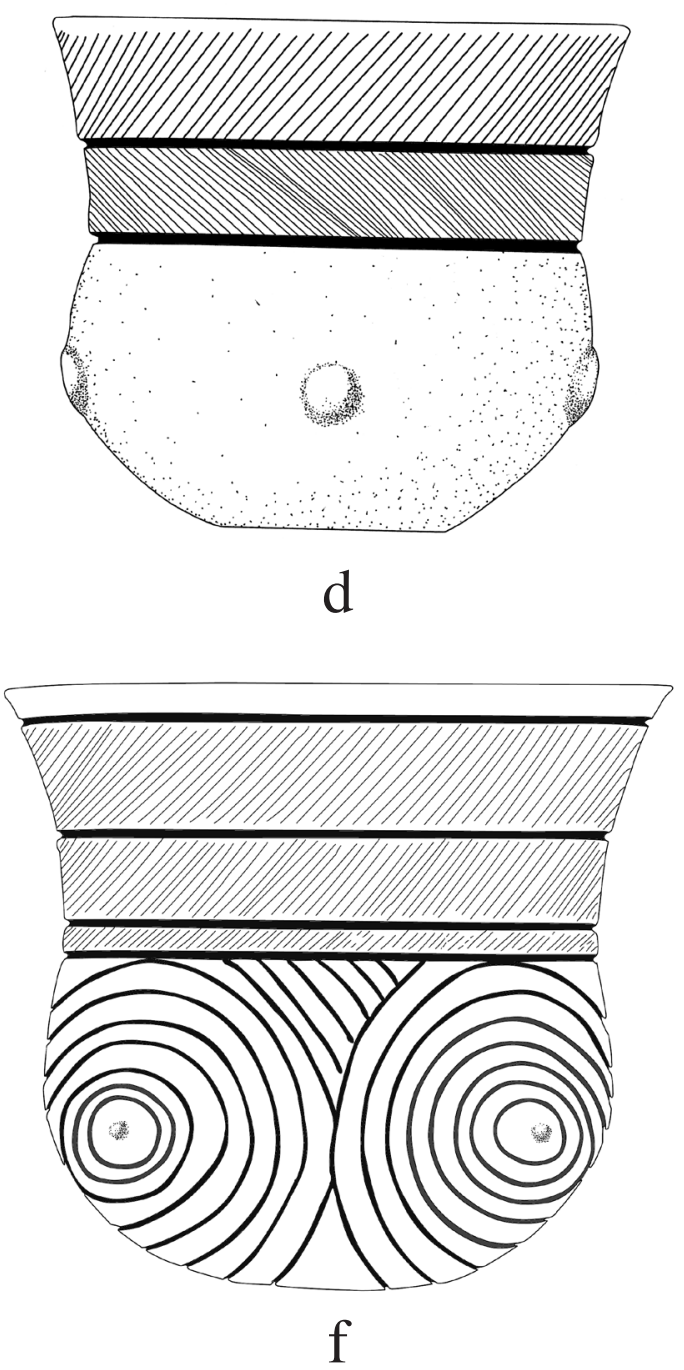

Figure 38. Vessels from Burial 2 in Zone F: a-b, Barkman Engraved carinated bowl; c-d, Foster Trailed-Incised, var. unspecified jar; e-f, Foster Trailed-Incised, var. Red Lake jar. Redrawn from Laughlin (1940). Photographs courtesy of TARL. 


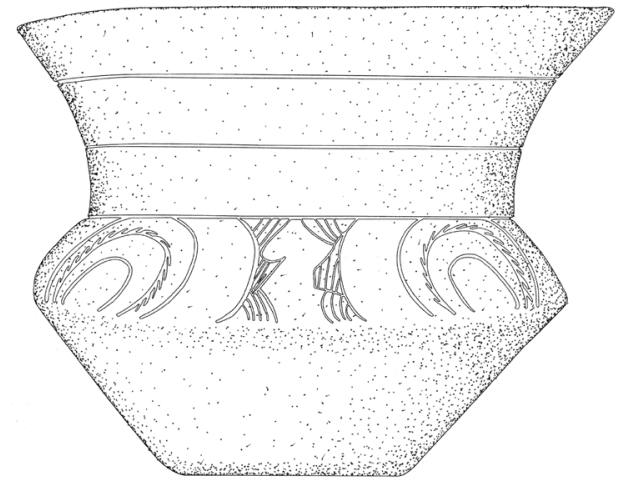

a

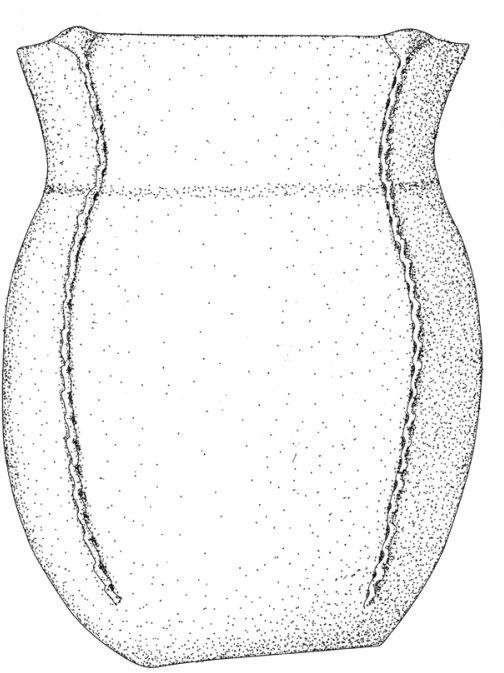

b
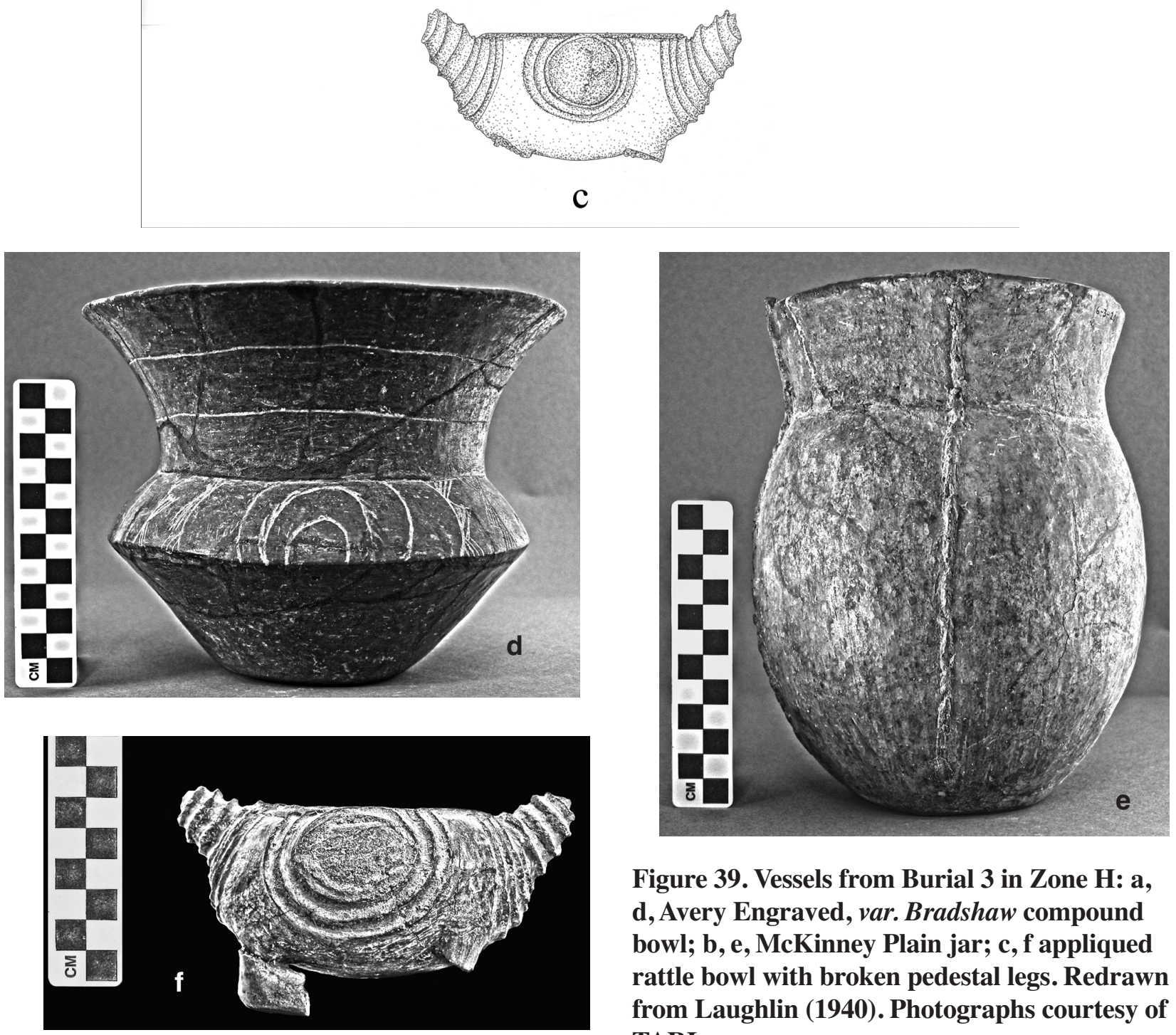

Figure 39. Vessels from Burial 3 in Zone H: a, d, Avery Engraved, var. Bradshaw compound bowl; b, e, McKinney Plain jar; c, f appliqued rattle bowl with broken pedestal legs. Redrawn from Laughlin (1940). Photographs courtesy of TARL. 


\section{Burial 4}

This burial was not associated with any particular mound zone because it appears to have been placed in a pit intruded into the lower part of the mound sometime after it had been constructed (TARL n.d.:378), and thus likely near the end of the mound's use, based on the presumed age of the associated ceramic vessels. It is an adult male, 40-50 years of age (Lee 1997:Table 2) and with arthritis and periostitis (Lee 1997:Tables 5 and 6), laid in an extended supine position, with three ceramic vessels placed between the knees; the deceased's head faced to the north-northwest (TARL n.d.:377). These vessels include a late $17^{\text {th }}$ century style Hodges Engraved, var. Candler spool neck bottle $(6.9 \mathrm{~cm}$ in height and $6.6 \mathrm{~cm}$ in diameter) (see Schambach and Miller 1984:122) (Figure 40a, d), a small plain bowl (5.8 $\mathrm{cm}$ in height and $8.3 \mathrm{~cm}$ in diameter) (Figure 40c, f), and a possible Hodges Engraved bowl $(7.9 \mathrm{~cm}$ in height and $8.2 \mathrm{~cm}$ in diameter) with a vertical interlocking scroll design with curvilinear engraved fill zones (Figure 40b, e).

\section{Temple Structure under the Mound}

Zone K represents the buried original ground surface (A-horizon) under the platform mound. The sediments in this zone are described by the WPA archaeologist as a "hard packed black humus" (TARL n.d.:385), which is taken to mean that the A-horizon sediments eventually covered by the mound (see Figure 14a-b) were organically stained by Caddo habitation debris and midden deposits. In the northern portion of the excavations under the platform mound, the clay B-horizon was reached without encountering any significant archaeological features. However, several significant archaeological features were identified in Zone K (Figure 41).

\section{Floor $\mathrm{K}$}

The one structure identified under the western part of the platform mound (Feature 25) is a very large circular structure, $14.98 \mathrm{~m}$ in diameter (Figures 42 and 43), with a surface area of $176.24 \mathrm{~m}^{2}$ (Schultz 2010:Table 20). This structure is about 60-80 percent larger than any of the circular structures on the platform mound itself (see Table 2), or the few structures excavated in the village (Perttula 2005). There are several small gaps in the walls that may represent entrances (Figure 43). Feature 25 also had an interior partition marked by an arc of post holes cutting across the northern part of the floor (TARL n.d.:401). It also has a gap between post holes, suggesting an entrance into the northern part of the structure; the eastern part of the partition is defined by two $1.5 \mathrm{~m}$ sections of shallow wall trench.

In addition to Feature 25 in Zone K, there is evidence of other structural features in these pre-mound deposits. These include two areas with partial alignments of post holes exposed in two trenches east and well east of Feature 25 (see Figure 41), along with a $9.2 \mathrm{~m}$ long ash deposit about $27 \mathrm{~m}$ northeast of Feature 25, near what became the central part of the platform mound as it was constructed; the width of this ash deposit was never established in the WPA excavations. This ash deposit likely represents the floor of another specialized structure, perhaps analogous to the cal. A.D. 1161-1254 ash-laden floor of the "House of the Priest" at the Crenshaw site (3MI6) on the Red River (Jackson et al. 2012). That structure was $9.5 \mathrm{~m}$ in length and $8.5 \mathrm{~m}$ in width, and was rectangular in shape (Jackson et al. 2012:53, 56). The ash deposit in Zone $\mathrm{K}$ at the Hatchel site may have a similar shape.

\section{Associated Material Culture Remains}

Associated with Feature 25 in Zone $\mathrm{K}$ is a Crockett Curvilinear Incised carinated bowl. The vessel is $8.9 \mathrm{~cm}$ in height and $15.2 \mathrm{~cm}$ in diameter (Figure 44a-b). 

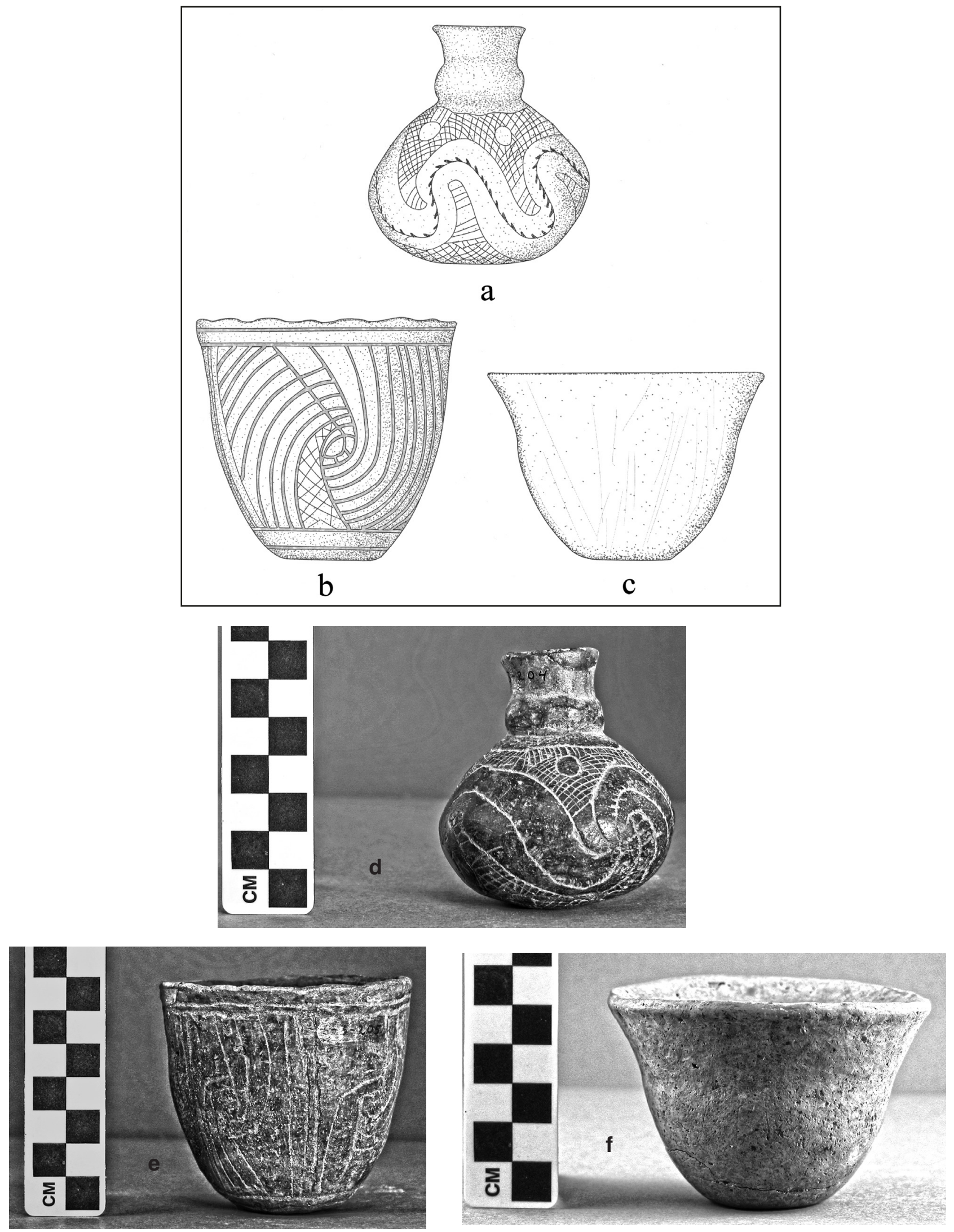

Figure 40. Vessels from Burial 4 in the platform mound at the Hatchel site: a, d, Hodges Engraved, var. Candler bottle; b, e, engraved bowl; c, f, plain bowl. Redrawn from Laughlin (1940). Photographs courtesy of TARL. 


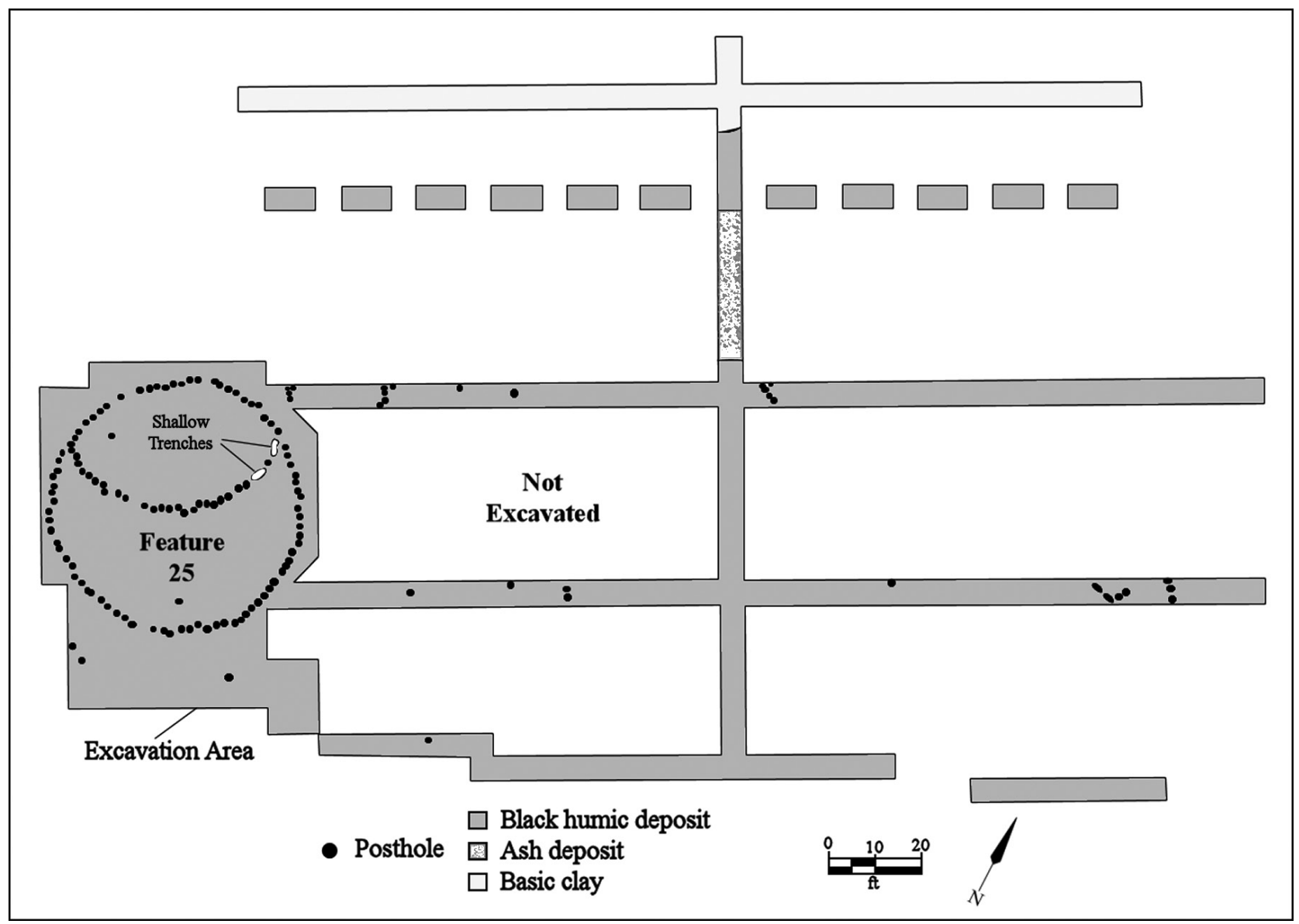

Figure 41. Plan of WPA excavations in Zone K pre-mound deposits.

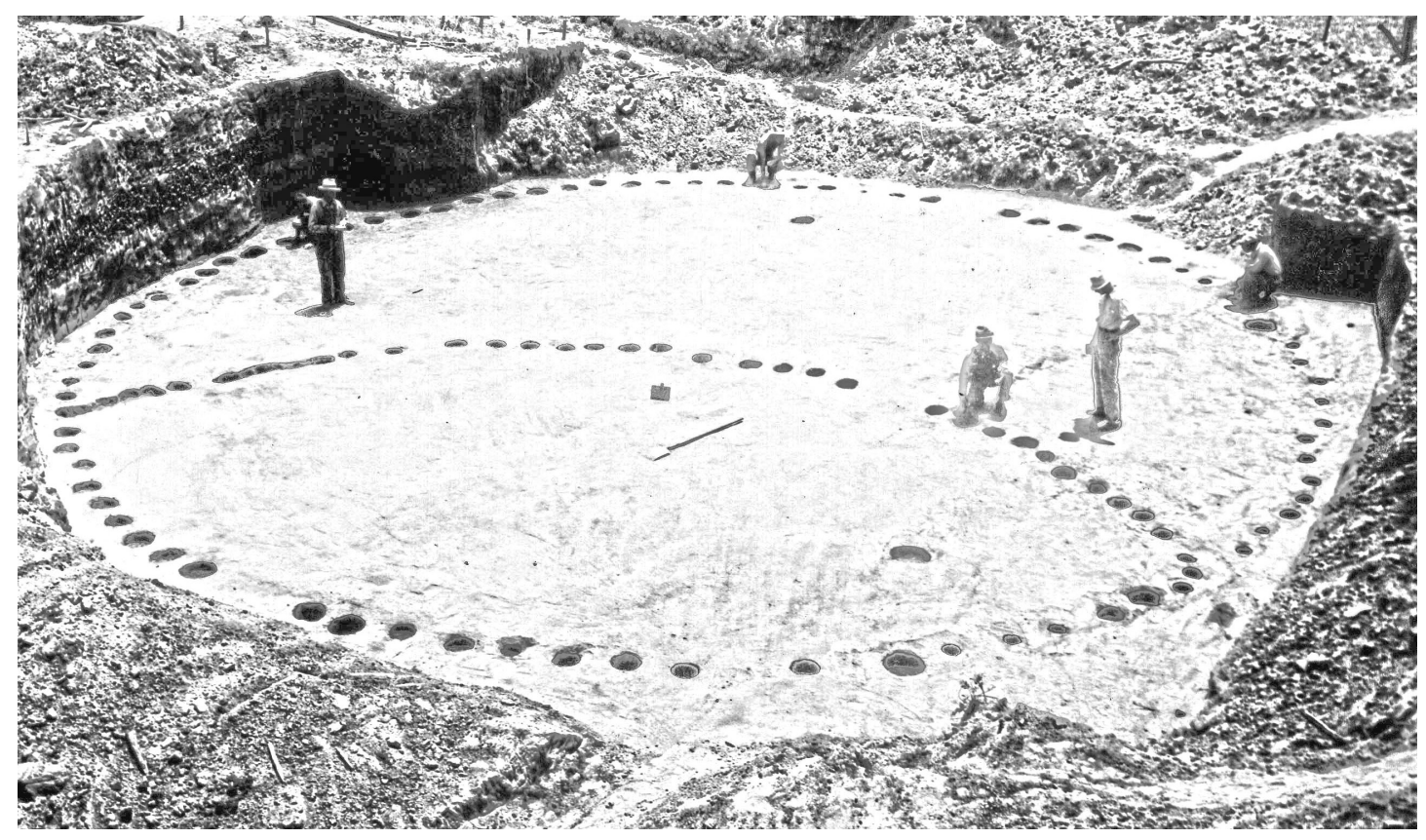

Figure 42. Feature 25 and its interior partition, in Zone $K$ under the platform mound, at the Hatchel site. Image 41BW3-265, Texas Archeological Research Laboratory, The University of Texas at Austin. 


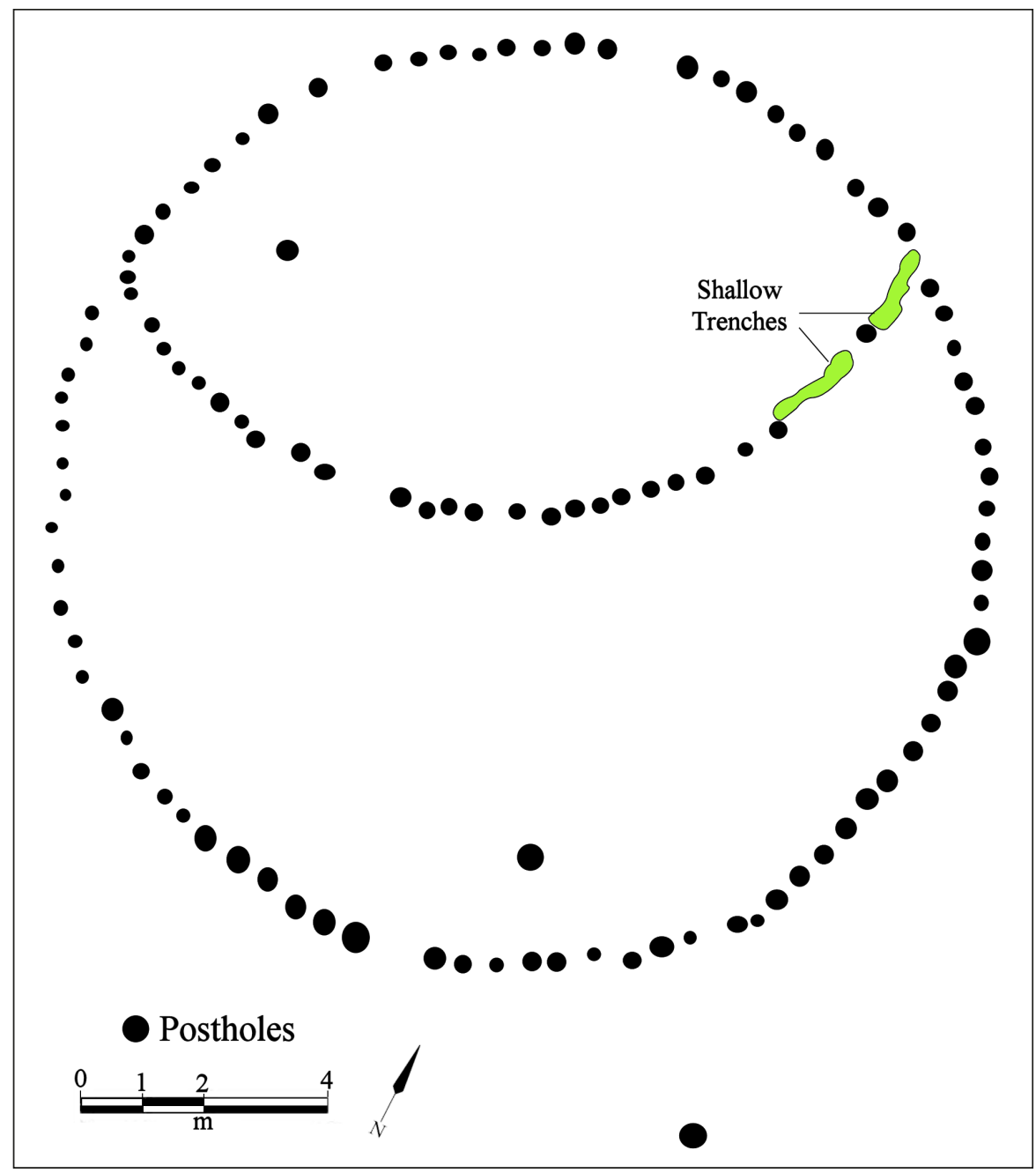

Figure 43. Plan map of Feature 25.

Also found in Zone $\mathrm{K}$ are a Red River long-stemmed pipe stem sherd, a mussel shell hoe, a rectangular-shaped ground stone celt (see Figure 33c), and a stemmed arrow point. This point has a long blade and a short contracting stem (see Figure 30h), and may be of the Bassett type.

\section{Summary and Conclusions}

The study of the architectural character of structures built by late prehistoric and early historic Native American societies in the southeastern United States has been particularly focused on a better appreciation of the social meaning of domestic structures within communities as well as the place of architecture of public buildings "conceived and planned by community leaders" (Hally 2008:121). These buildings are "a representation of temporal order" (Beck 2007:20) in the social and political realm, and the analysis of architectural structures has provided important insights into aboriginal views of the cosmos, social practice, and cultural change during Mississippian period times. The study of the architecture of specialized buildingsperhaps public in nature, but perhaps of more restricted access - on Caddo sites has also led to insights into how different Caddo societies and communities expressed beliefs in life and death, the cosmos, and the place of such buildings as foci for religious and political rituals and ceremonies (e.g., Kay and Sabo 2006; McKinnon 2013; Perttula 2009; Rogers 1982; Sabo 2012; Schambach 1996; Trubitt 2009). 

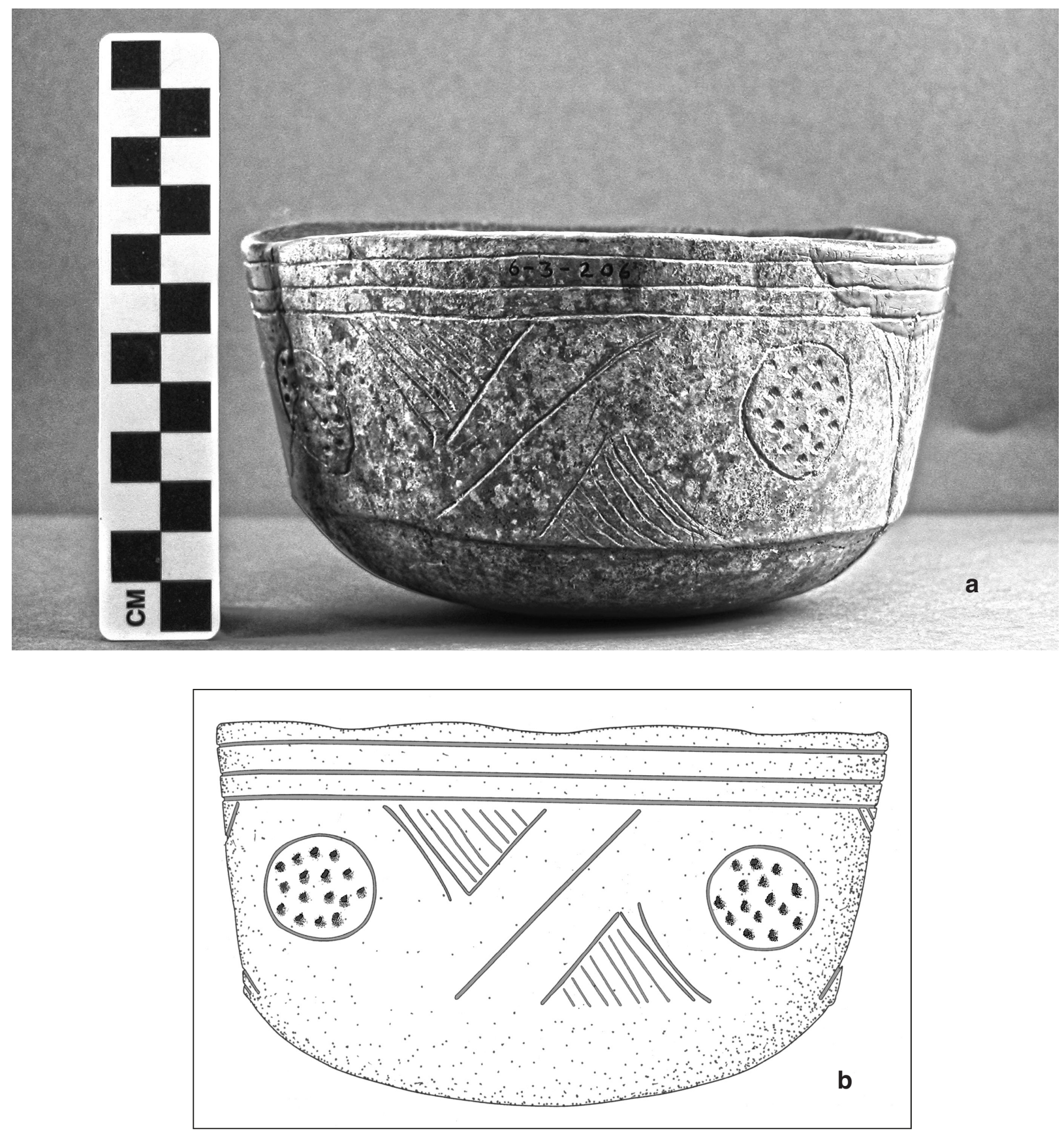

Figure 44. Crockett Curvilinear Incised carinated bowl from Zone K: a, photograph; b, redrawn from Laughlin (1940). Photograph courtesy of TARL.

According to Sabo (1998:168), Caddo houses are "considered a constituent element of a larger community," and they are "visible symbols of the interconnectedness of families and households comprising villages and communities." A specialized building that may have been used for important political and religious rituals by the social elite of a community or polity, or used for mortuary ceremonialism, or used even as an ancestor temple (e.g., Dye and King 2007:160-161), would stand above and apart in the Caddo constructed landscape. This would be the case with respect to its reflection in certain kinds of architectural features (i.e., central fires, house size, entranceways, and controlled access) of the superhuman power and sacredness principles that would have existed within the social hierarchy of any Caddo community 
(Sabo 1998:170), and the specialized rituals and ceremonies that took place in them, whether they were situated atop a platform mound, as in the case of the structures at the Hatchel site, or adjacent to such a mound feature (cf. Schambach 1996:40; Story 1990:340).

Extended entranceway structures are a conspicuous and widely distributed architectural construction on Caddo sites in both the southern and northern Caddo archaeological areas; circular extended entranceway structures on the platform mound (in six of the eight mound structure zones) at the Hatchel site are a notable aspect of the construction and use of temples and specialized use structures on this mound. This type of structure has long been thought to be indicative of an important or specialized Caddo structure, perhaps one lived in by the social elite or used for specialized and restricted purposes. There are other forms of specialized structures on Caddo sites, but J. Daniel Rogers (1982:49) provides a useful definition of these buildings:

Specialized buildings are considered as any of the variety of structures that provided a physical context for the integration of social organization beyond that of the household unit. These may include temples, meeting halls, charnel houses, and the residences of chiefs and other officials.

Rogers (1982:49) goes on to note that specialized buildings are often found in direct association with mounds or have characteristics different from contemporaneous domestic dwellings, including their extra large size; specific and distinctive kinds of construction details; as well as their method of abandonment or disposal (e.g., Early 1988:160-163, 2000b:70, 128). Specialized buildings may be found in mound centers as well as "ordinary village context" (Rogers 1982:49). Extended entranceways are another distinctive architectural characteristic of some Caddo specialized buildings. Brown (1996:132) points out that since "extended entranceways were employed to restrict the interior access [to structures] suggests the possibility that this architectural restriction in access may well have been reserved for bone houses [charnel houses] or elite residences."

Story (1998:26) considers special purpose buildings to be structures that were used by special persons for "other than as an everyday family residence." Jelks and Tunnell (1959:55) had concluded with respect to the extended entranceway structures at the Harroun site (41UR10) in the Big Cypress Creek basin in Northeast Texas that "because of the consistent pattern of burning, paucity of domestic artifacts, and burial of the house ruins beneath mounds, it is believed that the structures were ceremonial in function and that the burning was intentional." In the same respect, Early (2000b:128) has identified specialized structures (used for special events or by special people, namely the social and political elite) on Caddo sites in the Ouachita Mountains of southwestern Arkansas because of the special form of treatment they received when they were abandoned (i.e., "the careful burning and burial routine that disposed" of the structures).

Evidence from a wide range of Caddo mound sites with platform mounds in the southern Caddo area indicates that specialized structures of several different shapes were built on one or more mound platform levels. Only a few of the platform mounds have more than one or two mound structure zones buried in them, unlike the Hatchel site with its eight mound structure zones; at the Adair site (3GA1) on the upper Ouachita River in the Ouachita Mountains the main mound had a sequence of nine floors with burned structures, although their shape and size is not known (Trubitt 2009:241 and Table 1). Regnier (September 30, 2013, personal communication) notes that Mound A at the Grobin Davis site (34Mc253) on the Glover River in southeastern Oklahoma had at least nine different levels of mound construction in the $2 \mathrm{~m}$ high mound, but it is not clear how many of these mound construction episodes (dating from ca. A.D. 1230-1500) had structures on the mound summit. Overall in southwestern Arkansas, however, many of the specialized structures found on mounds were square or rectangular in shape (Early 2000b:129-130; Schambach 1996; Trubitt 
2009), although circular structures have also been noted on mound platforms (Trubitt 2009:240-242 and Table 1). In other parts of the southern Caddo area, circular temple structures are predominant, but there is considerable architectural diversity. For example, at the George C. Davis site (41CE19) in East Texas, the temple structures on as many as four platform levels in Mound A are mostly circular, as they are at the Hatchel site, although several are sub-square in shape (Newell and Krieger 1949; Schultz 2010; Spock 1977). At the Sanders (41LR2, Jackson et al. 2000) and Fasken (41RR14, Prikryl 2008) sites, the temple structures on mound platforms appear to be rectangular in shape, as do specialized structures under mounds at the Holdeman (41RR11, Perino 1995), Fasken, and Roitsch/Sam Kaufman (41RR16, Skinner et al. 1969; Perttula 2008b) sites in the mid-Red River basin, and in House 4 under Mound B at the Belcher site on the Red River in Northwest Louisiana (Webb 1959).

A particularly important part of the archaeological record preserved at many Caddo mound sites is the deposits and features associated with the construction and deliberate destruction of the grass-thatched wood structures occupied by the Caddo elite and domestic commoners. For example, Story (1998:14) has noted that the destruction and rebuilding of certain structures at the George C. Davis site appears to relate to a cycle of major ceremonies and rituals carried out during the life of the Caddo community; important structures were regularly and purposefully destroyed by fire (Story 1998:28, 31, 39). Schultz (2010:326) further notes that by:

following such a cycle, the Caddo political elite or ritual practitioners were apparently taping into the power and authority of the past, as well as integrating the power of the ancestors into their own time and place by appropriating and reusing sacred spaces or other spaces of power. The continued construction and use of specialized buildings atop the floors of earthen mounds, as well as the close vertical alignment of many of those structures with ones that came before, suggests a continuity of traditions related to the construction, use, and destruction of sacred spaces.

The use of fire, and its associated smoke and steam, in destroying important buildings has been a characteristic feature of Caddo societies since the $10^{\text {th }}$ century A.D. (Schambach 1996:41; Trubitt 2009:233). Trubitt (2009:233, 243-244) has commented that "the cleansing properties of smoke continued to be important to Caddo Indians into the twentieth century" for life/renewal ceremonies associated with mortuary rites and the burning of temples. Perhaps structures were burned after the mortuary rites of important individuals "as a way of conveying souls to the world of the dead along an axis mundi of smoke..." and temples or the residences of important persons were burned as "a way of terminating the use of it and cleansing the location" (Trubitt 2009:244).

Two of the better known Caddo mound sites with evidence of the cyclical construction, destruction, and burning of temple structures are the Belcher site (16CD13) in northwestern Louisiana (Webb 1959) and the Ferguson site (3HE63) in southwestern Arkansas (Schambach 1972, 1996). At the Belcher site, the structures, covered with wattle and daub, and with grass thatched roofs, were situated on conjoined Mounds A and B and a connecting low platform or third mound (Webb 1959:Figure 4). The mound platform was about $55 \mathrm{~m}$ in length, not much different in length than at Hatchel, but the platform was the result of four construction events that took place over apparently more than several hundred years, instead of the nine construction events in the Hatchel platform mound that seemingly took place in less than an estimated 200 years. Except for the rectangular structure (House 4) under Mound B, the other seven structures under or on the mounds were circular and ranged from 9.1-12.2 $\mathrm{m}$ in diameter (Kelley 2012:415). The larger structures were on Mound A, and the largest circular structures were built during the Belcher phase (Belcher III and IV) (Webb 1959:59). There also seems to have been two structures per mound structure zones at Belcher, again not much different than in the mound structure zones at the Hatchel site. 
Unlike the circular structures on the platform mound at the Hatchel site, most (89\%) of the structures on the conjoined mounds at the Belcher site had central hearth basins filled with ash. Several also had masses of daub (House 1, House 2, and House 4), all in Mound B (Webb 1959), while others had very little daub, much like the situation with the structures in the different mound zones in the Hatchel mound. Other distinctive features of the Belcher site structure were ash beds along the walls or in entranceways (Houses 2 and 4, Webb 1959:Figures 14 and 23). In House 6, there were large ash beds encircling the walls and an ash-filled trench entranceway covered with sand (Webb 1959:44 and Figure 32), and House 7 also had a number of ash beds encircling much of the walls (Webb 1959:Figure 39). The extended entranceway to House 8 was a combination of posts and trenches (Webb 1959:Figure 46). Although House 3 is interpreted by Webb (1959:36) as two different circular structures, it is possible that Houses 3a and $3 \mathrm{~b}$ represent the construction of a double-walled structure similar to Features 19/20 and 22 at the Hatchel site. The profile of Mound B at Belcher suggests a single House 3 floor level (Webb 1959:Figure 8).

The one rectangular structure and four of the circular structures at the Belcher site had extended entranceways that faced to the northeast (Webb 1959:Figures 12, 14, 20, 23, 28, 32, 39, and 46), and the entrances were typically superimposed. The Belcher site mound sequence is distinctive because after the structures had been burned and covered with mound fill and burned structure debris, numerous burial pits, many containing multiple individuals and abundant funerary offerings, were excavated through the debris before another structure was erected over them (Webb 1959:182-183). There are no such burial pits in the platform mound at the Hatchel site. Webb (1959:201) suggests that the burning and immolation of houses or temples in the Belcher site mounds was done "in connection with burials of important persons." It appears to be the case that "two structures... stood simultaneously on the conjoined mounds, suggesting that one may have served as a specialized religious structure, while the other was the residence of the caddi" (Kelley 2012:412).

Excavations at the Ferguson site have not been completely reported to date, but according to Schambach (1972:10 and Figures 6-9, 1996:41 and Figures 5.8-5.11), Mound A was a Middle Caddo period, Haley phase, two stage structure - possibly constructed in the $14^{\text {th }}$ century A.D. (Ann Early, September 30,2013 , personal communication) - with a low northern platform ( $3 \mathrm{~m}$ in height) and a higher $(6.5 \mathrm{~m}$ in height) southern platform. The northern platform had 10 buildings from five different levels, two per level, "one square building with wattle and daub walls for winter use, and one circular building with thatched walls for summer use" (Ferguson 1996:41). Schambach (1996:41) suggests these structures were periodically, but accidentally burned (producing considerable amounts of daub and small amounts of carbonized wood) and without obvious ceremony, and that the structures were domestic dwellings. However, I think the context of these buildings - their being situated on one of the platforms on the platform mound - argues against these being domestic dwellings, and it is much more likely that they were the residences of a political or religious leader, perhaps the caddi for the community. In any event, these structures on the north platform were apparently occupied at the same time as the series of five structures on the south platform at the Ferguson site, structures that Schambach (1996:41) thinks are temples. These southern platform structures "were all square, with extended door passages, thatched roofs, and cane matting walls." The structures were represented by great quantities of carbonized logs and other structural debris because they "were all burned and buried according to the same careful ritual" (Schambach 1996:41), which was to push in the burning walls, quickly cover them with sand (already piled around the walls), thus smothering the fire and leading to the excellent preservation of the carbonized remains. Schambach (1996:41) also suggests that for:

the Caddo, one immediate objective of this ritual may have been to produce the great plume of smoke and steam that must have emanated from each burned and buried building for days or even weeks, as a cord or more of wood was slowly reduced to charcoal. 
In summary, the platform mound at the Hatchel site was constructed over at least two specialized structures at what was the original ground surface (Zone K). These structures consisted of a very large circular structure with an internal partition and a structure of unknown size marked by an extensive ash deposit. The few artifacts that have been recovered from Zone $\mathrm{K}$ - as well as an artifact assemblage from nearby Village Area I (see Figure 1b; see also Perttula and Nelson 2003) that is believed to be associated with Zone $\mathrm{K}$ - suggests that these structures were an important and central part of a pre-A.D. 1300 Caddo community at the Hatchel site, and remained so in the memories and ceremonies of later Nasoni Caddo peoples. At least 100 years later or perhaps even longer, by ca. A.D. 1450, the first stages of the platform mound were constructed, and a ramp was built along the southern side of the mound, heading down into the Texarkana phase Nasoni Caddo village that had grown up at Hatchel. These first stages of the platform mound did not have temple structures constructed on them.

The second stage in the construction of the platform mound at the Hatchel site consisted of a stratified series of constructed structures on the northern part of the mound platform. Most of this construction seemingly took place after ca. A.D. 1550, and may have lasted until ca. A.D. 1690, although no European artifacts have been recovered from any of these mound deposits. These structures were in eight different mound zones (Zones A-H), in many cases with structures superimposed over one another, even though they were separated by mound fill. There were 16 circular structures in the mound structure zones, ranging from one (Zones F and G), two (Zones A-E), and three (Zone H) structures per zone; a third structure in Zone B appears to have been a granary, not a specialized structure associated with rituals and ceremonies on the platform mound. That most of the zones have two structures - situated at the eastern and western ends of the platform - may be an expression of the basic duality identified by Sabo (2012:439, 441) in Caddo cosmology and social organization, and the fact that different rituals were performed in these simultaneously used Nasoni Caddo temple structures. In Zones F, G, and H, other cosmological and social rituals and principles of the spirit realm expressed in deliberate spatial differences from later mound structure zones may have held sway.

Where entrances can be identified in these structures, they were facing to the south or southeast, in the same direction as the ramp that was attached to the principal platform mound, and thus facing in the direction of the central part of the Nasoni Caddo village and other mounds in the larger community. If there was a plaza at the Hatchel site - as suggested by the 1691 Teran map (see Sabo 2012:Figure 15-1; this is assuming that the Hatchel mound is the temple mound shown on that map) - it appears to be associated with only the latest mound zones, because post-A.D. 1600 village occupations occur near the platform mound in several village areas (see Figure 1b). Extended entranceway structures are present in six of the eight mound structure zones; two structures in Zones $\mathrm{G}$ and $\mathrm{H}$ have double walls; and one structure in Zone $\mathrm{H}$ has an exterior post partition. All these features were likely designed to restrict access to the buildings, probably marking a tangible boundary "between the human and spirit realms" (Sabo 2012:442).

At regular intervals over more than 100 years, these mound structures were dismantled, destroyed, and burned. The few masses of daub, ash, and charred wood/charcoal found in association with the mound structures suggests that: (a) the structures were likely mainly thatch-covered, without wattle and daub walls (although at least one structure seems to have had a wattle and daub covered extended entranceway [Feature 7 in Zone C]), and (b) whatever burned and dismantled structural debris there was then removed from the structures themselves, and became incorporated in the next mound fill zone that covered the structures.

If the platform mound at the Hatchel site is the temple mound and templo structure shown on the 1691 Teran map, then it seems likely that one of the structures in the latest mound zone, Zone A, is the 1691 
templo. Feature 1 at the eastern end of the platform mound in this zone is a circular structure with extensive ash deposits on the floor (see Figure 15). Both Schambach (1996:41) and Sabo (2012:435) suggest that the templo was partially buried within the mound, likely because there were soil berms placed around it. The WPA excavations in Zone A - as well as in the other mound structure zones - did not identify evidence of any such soil berms associated with Feature 1; Zone A was covered with only a thin mound fill before the platform mound was abandoned (see Figure 14b). Hopefully radiocarbon dates can be obtained from features in Zone 1 to determine if it is temporally associated with the templo depicted on the Teran map.

\section{Acknowledgments}

I would like to thank Clay Schultz, for opening his Hatchel files for me, and Lance Trask, who prepared the figures, several quite challenging, in this publication. I also appreciate the information provided by Ann Early, Jeff Girard, Amanda Regnier, and Mary Beth Trubitt concerning structures on Caddo platform mounds. Finally, I appreciate the permission of the Texas Archeological Research Laboratory at The University of Texas at Austin to reproduce a number of the WPA photographs of the archaeological excavations at the Hatchel site, and for their help in accessing and copying WPA records.

\section{References Cited}

Anderson, D. G.

2012 Monumentality in Eastern North America during the Mississippian Period. In Early New World Monumentality, edited by R. L. Burger and R. M. Rosenwig, pp. 78-108. University Press of Florida, Gainesville.

Beck, R. A., Jr.

2007 The Durable House: Material, Metaphor, and Structure. In The Durable House: House Society Models in Archaeology, edited by R. A. Beck, Jr., pp. 3-24. Occasional Paper No. 35. Center for Archaeological Investigations, Southern Illinois University, Carbondale.

Blitz, J. H.

2010 New Perspectives in Mississippian Archaeology. Journal of Archaeological Research 18(1):1-39.

Brown, J. A.

1996 The Spiro Ceremonial Center: The Archaeology of Arkansas Valley Caddoan Culture in Eastern Oklahoma. 2 Vols. Memoirs No. 29. Museum of Anthropology, University of Michigan, Ann Arbor.

2010 Cosmological Layouts of Secondary Burials as Political Instruments. In Mississippian Mortuary Practices: Beyond Hierarchy and the Representationist Perspective, edited by L. P. Sullivan and R. C. Mainfort, Jr., pp. 30-53. University Press of Florida, Gainesville.

Butler, B. M. and P. D. Welch (editors)

2006 Leadership and Polity in Mississippian Society. Occasional Paper No. 33. Center for Archaeological Investigations, Southern Illinois University, Carbondale.

Creel, D. G.

1996 Hatchel-Mitchell Site. In The New Handbook of Texas, Vol. 3, edited by R. Tyler, pp. 504-505. Texas State Historical Association, Austin. 
Dye, D. H. and A. King

2007 Desecrating the Sacred Ancestor Temples: Chiefly Conflict and Violence in the American Southeast. In North American Indigenous Warfare and Ritual Violence, edited by R. J. Chacon and R. G. Mendoza, pp. 160-181. University of Arizona Press, Tucson.

Early, A. M.

1988 Standridge: Caddoan Settlement in a Mountain Environment. Research Series No. 29. Arkansas Archeological Survey, Fayetteville.

2000a The Caddos of the Trans-Mississippi South. In Indians of the Greater Southeast, edited by B. G. McEwan, pp. 122-141. University Press of Florida, Gainesville.

2004 Prehistory of the Western Interior after 500 B.C. In Handbook of North American Indians, Southeast, Volume 14, edited by R. B. Fogelson, pp. 560-573. Smithsonian Institution, Washington.

Early, A. M. (editor)

2000b Forest Farmsteads: A Millennium of Human Occupation at Winding Stair in the Ouachita Mountains. Research Series 57. Arkansas Archeological Survey, Fayetteville.

Girard, J. S.

2010 Caddo Communities of Northwest Louisiana. In Archaeology of Louisiana, edited by M. A. Rees, pp. 195-210. Louisiana State University Press, Baton Rouge.

Hally, D. J.

2008 King: The Social Archaeology of a Late Mississippian Town in Northwestern Georgia. University of Alabama Press, Tuscaloosa.

Hatcher, M. A.

1999 The Expedition of Don Domingo Teran de los Rios into Texas. In Wilderness Mission: Preliminary Studies of the Texas Catholic Historical Society, II, edited by J. F. de la Teja, pp. 1-66. Studies in Southwestern Catholic History No. 2. Texas Catholic Historical Society, Austin.

Jackson, A. T.

2003 Hatchel Site and Paul Mitchell Cemetery. Caddoan Archeology Journal 13 (No. 2):25-27.

2004 Excavation of an Earth Mound, Bowie County, Texas. Caddoan Archeology Journal 13 (No. 3/4):57-64.

Jackson, A. T., M. S. Goldstein, and A. D. Krieger

2000 The 1931 Excavations at the Sanders Site, Lamar County, Texas: Notes on the Fieldwork, Human Osteology, and Ceramics. Archival Series 2. Texas Archeological Research Laboratory, The University of Texas at Austin.

Jackson, H. E., S. L. Scott, and F. F. Schambach

2012 At the House of the Priest: Faunal Remains from the Crenshaw Site (3MI6), Southwest Arkansas. In The Archaeology of the Caddo, edited by T. K. Perttula and C. P. Walker, pp. 47-85. University of Nebraska Press, Lincoln. 
Jelks, E. B. and C. D. Tunnell

1959 The Harroun Site, A Fulton Aspect Component of the Caddoan Area, Upshur County, Texas. Archaeology Series No. 2. Department of Anthropology, The University of Texas at Austin.

Kay, M. and G. Sabo III

2006 Mortuary Ritual and Winter Solstice Imagery of the Harlan-Style Charnel House. Southeastern Archaeology 25(1):29-47.

Kleinschmidt, U. K. W.

1982 Review and Analysis of the A. C. Saunders Site, 41AN19, Anderson County, Texas. Master's thesis, Department of Anthropology, The University of Texas at Austin.

Krieger, A. D.

1946 Culture Complexes and Chronology in Northern Texas With Extension of Puebloan Datings to the Mississippi Valley. Publication No. 4640. The University of Texas, Austin.

Laughlin, J. T.

1940 Laboratory Study of the Pottery, Potsherds and Artifacts from Site ET-30 Mound. MS on file, Texas Archeological Research Laboratory, The University of Texas at Austin.

Lee, $\mathrm{C}$.

1997 Paleopathology of the Hatchel-Mitchell-Moores Sites, Bowie County, Texas. Bulletin of the Texas Archeological Society 68:161-177.

McKinnon, D. P.

2013 Landscape as a Ritual Object: Exploring Some Thoughts on Organized Space in the Great Bend Region of Southwestern Arkansas. Caddo Archeology Journal 23:67-84.

Newell, H. P and A. D. Krieger

1949 The George C. Davis Site, Cherokee County, Texas. Memoir No. 5. Society for American Archaeology, Menasha, Wisconsin.

Perino, G.

1995 The Dan Holdeman Site (41RR11), Red River County, Texas. Journal of Northeast Texas Archaeology 6:3-65.

Perttula, T. K.

1992 "The Caddo Nation": Archaeological and Ethnohistoric Perspectives. University of Texas Press, Austin.

1998 A Compendium of Radiocarbon and Oxidizable Carbon Ratio Dates from Archaeological Sites in East Texas, with a Discussion of the Age and Dating of Select Components and Phases. Radiocarbon 39(3):305-342.

2005 1938-1939 WPA Excavations at the Hatchel Site (41BW3) on the Red River in Bowie County, Texas. Southeastern Archaeology 24(2):180-198.

2009 Extended Entranceway Structures in the Caddo Archaeological Area. Southeastern Archaeology 28(1):27-42. 
Perttula, T. K. and B. Nelson

2003 Archeological Investigations of Village Areas at the Hatchel Site (41BW3), Bowie County, Texas. Report of Investigations No. 58. Archeological \& Environmental Consultants, LLC, Austin.

Perttula, T. K., J. E. Bruseth, N. A. Kenmotsu, and W. A. Martin

1995 Archeological Testing at the Cabe Mounds (41BW14), Bowie County, Texas. Cultural Resource Management Report 8. Department of Antiquities Protection, Texas Historical Commission, Austin.

Perttula, T. K., R. Z. Selden, Jr., and D. Wilson

2014 Corn is Life: Temporal Trends in the Use of Corn (Zea mays) by Caddo Peoples from Radiocarbondated Samples and Stable Isotope Analyses. Bulletin of the Texas Archeological Society 85, in press.

Perttula, T. K., C. P. Walker, and T. C. Schultz

2008 A Revolution in Caddo Archaeology: The Remote Sensing and Archaeological View from the Hill Farm Site (41BW169) in Bowie County, Texas. Southeastern Archaeology 27(1):93-107.

Prikryl, D. J.

2008 The 1991 and 1992 Texas Archeological Society Field School Excavations at the Fasken Site (41RR14), Red River County, Texas. In Collected Papers from Past Texas Archeological Society Summer Field Schools, edited by T. K. Perttula, pp. 125-171. Special Publication No. 5. Texas Archeological Society, San Antonio.

Rogers, J. D.

1982 Spiro Archaeology: 1980 Research. Studies in Oklahoma's Past Number 9. Oklahoma Archeological Survey, Norman.

Sabo, G., III

1998 The Structure of Caddo Leadership in the Colonial Era. In The Native History of the Caddo: Their Place in Southeastern Archeology and Ethnohistory, edited by T. K. Perttula and J. E. Bruseth, pp. 159-174. Studies in Archeology 30. Texas Archeological Research Laboratory, The University of Texas at Austin.

2012 The Teran map and Caddo Cosmology. In The Archaeology of the Caddo, edited by T. K. Perttula and C. P. Walker, pp. 431-447. University of Nebraska Press, Lincoln.

Schambach, F. F.

1972 Preliminary Report on the 1972 Excavations at the Ferguson Site (3HE63). The Arkansas Archaeologist 13(1-2):1-13.

1996 Mounds, Embankments, and Ceremonialism in the Trans-Mississippi South. In Mounds, Embankments, and Ceremonialism in the Midsouth, edited by R. C. Mainfort and R. Walling, pp. 36-43. Research Series No. 46. Arkansas Archeological Survey, Fayetteville.

Schambach, F. F., and J. E. Miller

1984 A Description and Analysis of the Ceramics. In Cedar Grove: An Interdisciplinary Investigation of a Late Caddo Farmstead in the Red River Valley, edited by N. L. Trubowitz, pp. 109-170. Research Series No. 23. Arkansas Archeological Survey, Fayetteville. 
Schultz, T. C.

2010 Architectural Variability in the Caddo Area of Eastern Texas. Special Publication No. 16. Friends of Northeast Texas Archaeology, Pittsburg and Austin.

Skinner, S. A., R. K. Harris, and K. M. Anderson (editors)

1969 Archaeological Investigations at the Sam Kaufman Site, Red River County, Texas. Contributions in Anthropology No. 5. Department of Anthropology, Southern Methodist University, Dallas.

Spock, C.

1977 An Analysis of the Architectural and Related Features at the George C. Davis Site. Master's thesis, Department of Anthropology, The University of Texas at Austin.

Story, D. A.

1990 Cultural History of the Native Americans. In The Archeology and Bioarcheology of the Gulf Coastal Plain, by D. A. Story, J. A. Guy, B. A. Burnett, M. D. Freeman, J. C. Rose, D. G. Steele, B. W. Olive, and K. J. Reinhard, pp. 163-366. 2 Vols. Research Series No. 38. Arkansas Archeological Survey, Fayetteville.

1997 1968-1970 Archeological Investigations at the George C. Davis Site, Cherokee County, Texas. Bulletin of the Texas Archeological Society 68:1-113.

1998 The George C. Davis Site: Glimpses into Early Caddoan Symbolism and Ideology. In The Native History of the Caddo: Their Place in Southeastern Archeology and Ethnohistory, edited by T. K. Perttula and J. E. Bruseth, pp. 9-43. Studies in Archeology 30. Texas Archeological Research Laboratory The University of Texas at Austin.

Styles, B. W. and J. R. Purdue

1984 Faunal Exploitation at the Cedar Grove Site. In Cedar Grove: An Interdisciplinary Investigation of a Late Caddo Farmstead in the Red River Valley, edited by N. L. Trubowitz, pp. 211-226. Research Series No. 23. Arkansas Archeological Survey, Fayetteville.

Suhm, D. A., and E. B. Jelks (editors)

1962 Handbook of Texas Archeology: Type Descriptions. Special Publication No. 1, Texas Archeological Society, and Bulletin No. 4, Texas Memorial Museum, Austin. Reprinted in 2009, Gustav's Library, Davenport, Iowa.

Sundermeyer, S. A., J. T. Penman, and T. K. Perttula

2008 Integrated Cultural Resources Investigations for the Bowie County Levee Realignment Project, Bowie County, Texas, and Little River County, Arkansas. Miscellaneous Reports, Report of Investigations No. 29. LopezGarcia Group, Dallas.

Texas Archeological Research Laboratory, The University of Texas at Austin (TARL)

n.d. Field Notes, Site ET-30, A. J. Hatchel Place, 11 Miles Northwest of Texarkana, Bowie County, Texas, Excavated from November 1, 1938, to August 25, 1939. Binders No. 2-4. Notes on file at the Texas Archeological Research Laboratory, The University of Texas at Austin.

Trubitt, M. B.

2009 Burning and Burying Buildings: Exploring Variation in Caddo Architecture in Southwest Arkansas. Southeastern Archaeology 28(2):233-247. 
Trubowitz, N. L. (editor)

1984 Cedar Grove: An Interdisciplinary Investigation of a Late Caddo Farmstead in the Red River Valley. Research Series No. 23. Arkansas Archeological Survey, Fayetteville.

Webb, C. H.

1959 The Belcher Mound: A Stratified Caddoan Site in Caddo Parish, Louisiana. Memoirs No. 16. Society for American Archaeology, Salt Lake City.

Wedel, M. M.

1978 La Harpe's 1719 Post on Red River and Nearby Caddo Settlements. Bulletin 30. Texas Memorial Museum, Austin. 



\section{Part II}

\section{Detailed Analysis of the Ceramic Sherds from Village Plot 1 Excavations at the Hatchel Site (41BW3)}

\section{Timothy K. Perttula}

\section{Introduction}

During 1938-1939 Works Progress Administration (WPA) archaeological investigations of one of the many village areas in the Nasoni Caddo community at the Hatchel site on the Red River (see Perttula 2005), a large assemblage of ceramic vessel sherds was recovered in the work. This assemblage, from Village Plot 1, apparently is associated with a substantial post-A.D. 1400 Late Caddo, Texarkana phase occupation (cf. Creel 1996) and village compounds (Figure 1) in this part of the village and this part of the Red River bottomlands (Figure 2), although no specific analyses of the sherds from this area has been previously completed.

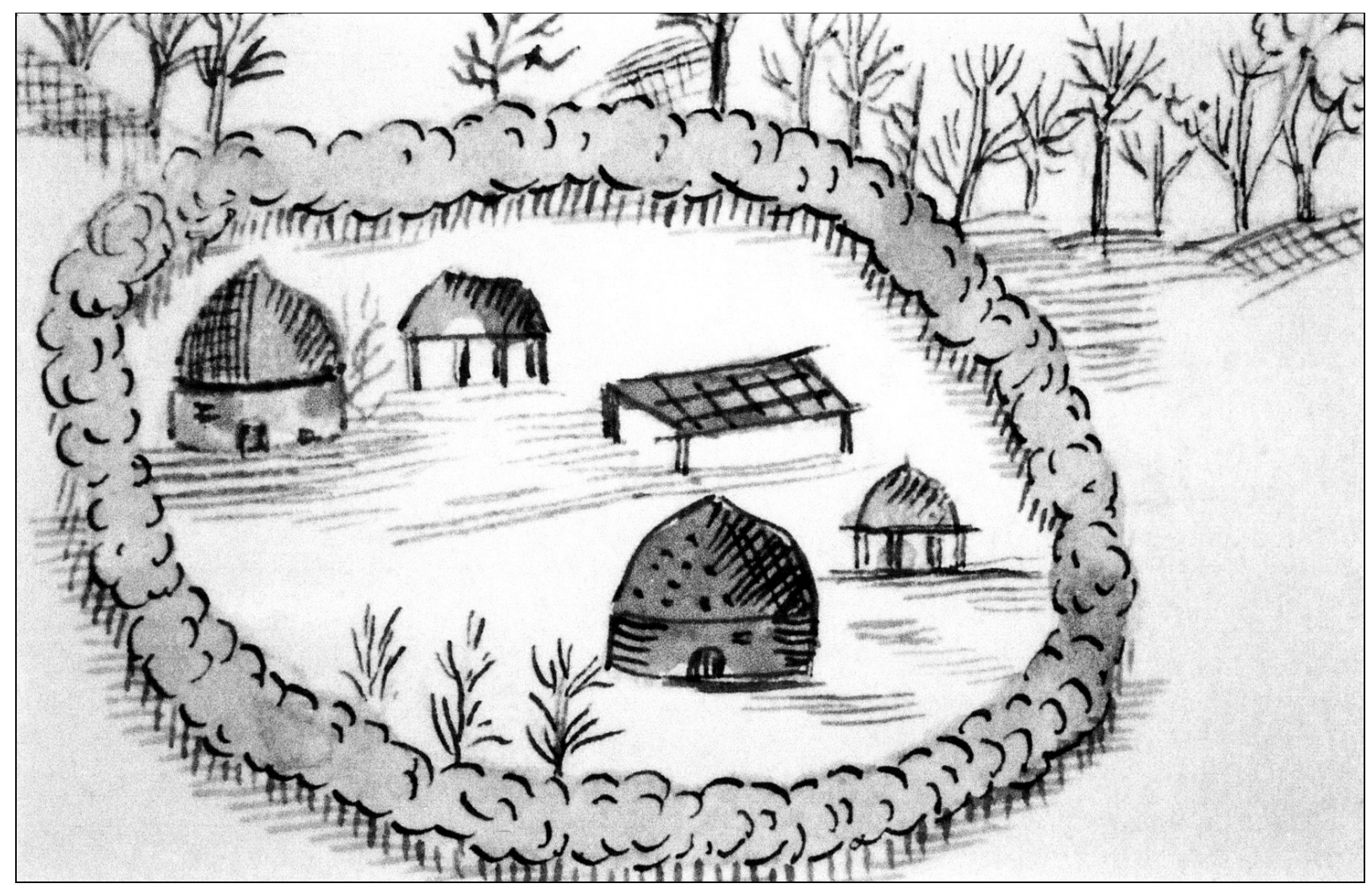

Figure 1. Nasoni Caddo compound as shown on the 1691 Teran map of the Nasoni Caddo village. (Redrawn from the original in the J. P. Bryan Map Collection, CT0108, Center for American History at The University of Texas at Austin.) 


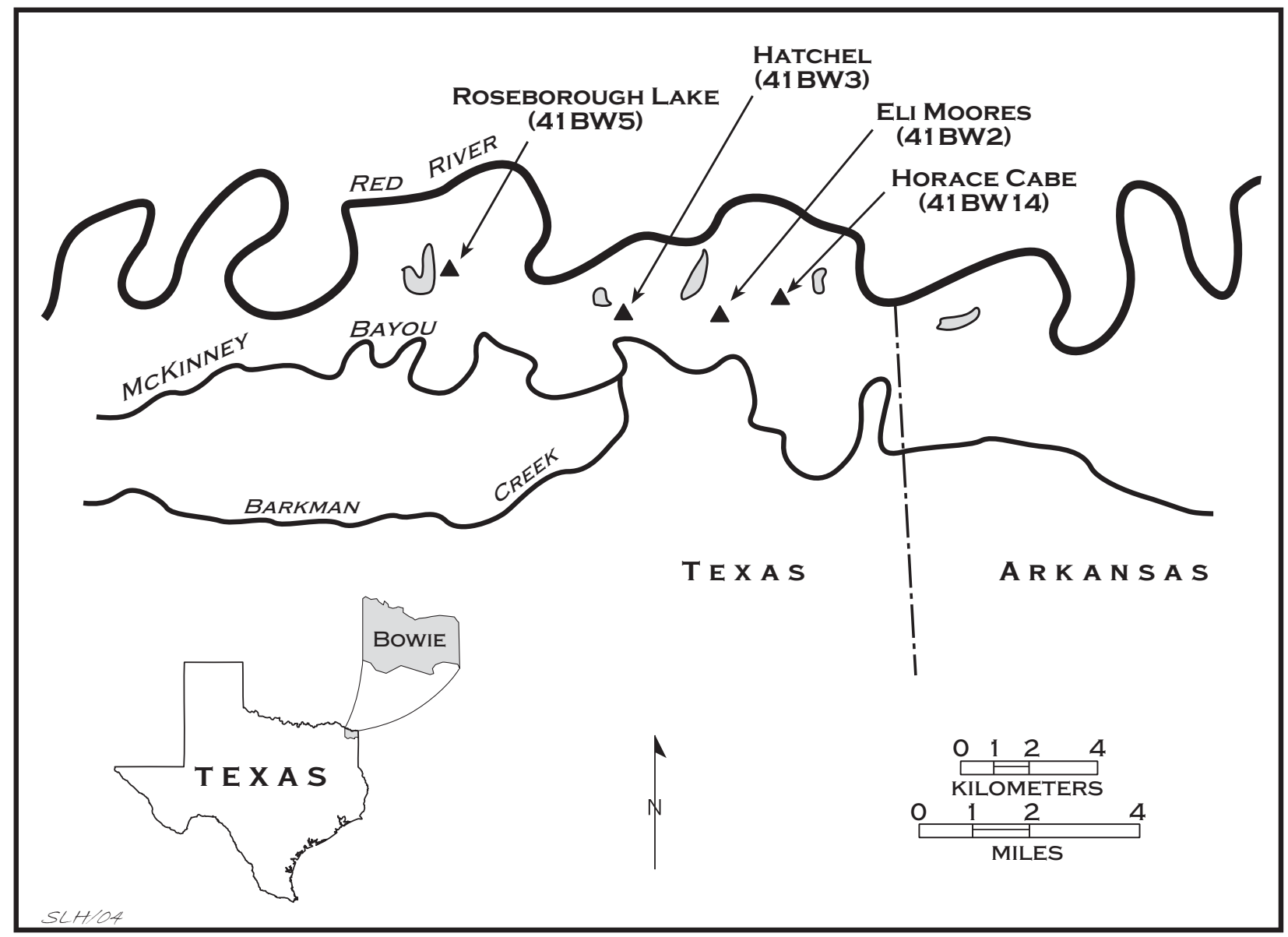

Figure 2. The Hatchel site and other contemporaneous Late Caddo, Texarkana phases sites along the Red River.

This part of Special Publication No. 23 provides a detailed analysis of the 1550 plain and decorated ceramic sherds from one of the village areas at the Hatchel site (Figure 3). In this analysis, I also mention sherds collected by the WPA from the surface of Village Plot 2 and Burial Plots 1-4. In total the assemblage from Village Plot 1 includes 1218 plain rim, body, and base sherds and 332 decorated rim and body sherds. The plain to decorated sherd ratio is 3.67 .

\section{Analytical Perspective}

Studies of prehistoric ceramic assemblages provide valuable information about Native American cultural adaptations, and offer a means of addressing chronology and cultural-temporal frameworks as well as technological and stylistic attributes particular to the assemblage itself. The analysis must be comprehensive enough to capture the array of stylistic and technological diversity found in the assemblage. When sherds large enough to exhibit overall design motifs are present in the assemblage, typological classifications are possible. In the absence of whole vessels or vessel sections large enough to discern typologically distinct decorative motifs, another way to distinguish subtle differences between relatively similar ceramics in an assemblage is to look at the stylistic and technological variations found on individual sherds. Recent research indicates that for Caddo potters in East Texas, variations in key technological attributes such as temper, surface treatment, firing conditions, and thickness bear a direct relationship to the desired use of a vessel (see Perttula 2013; Perttula and Ellis 2012). Thus, sherds recovered from 


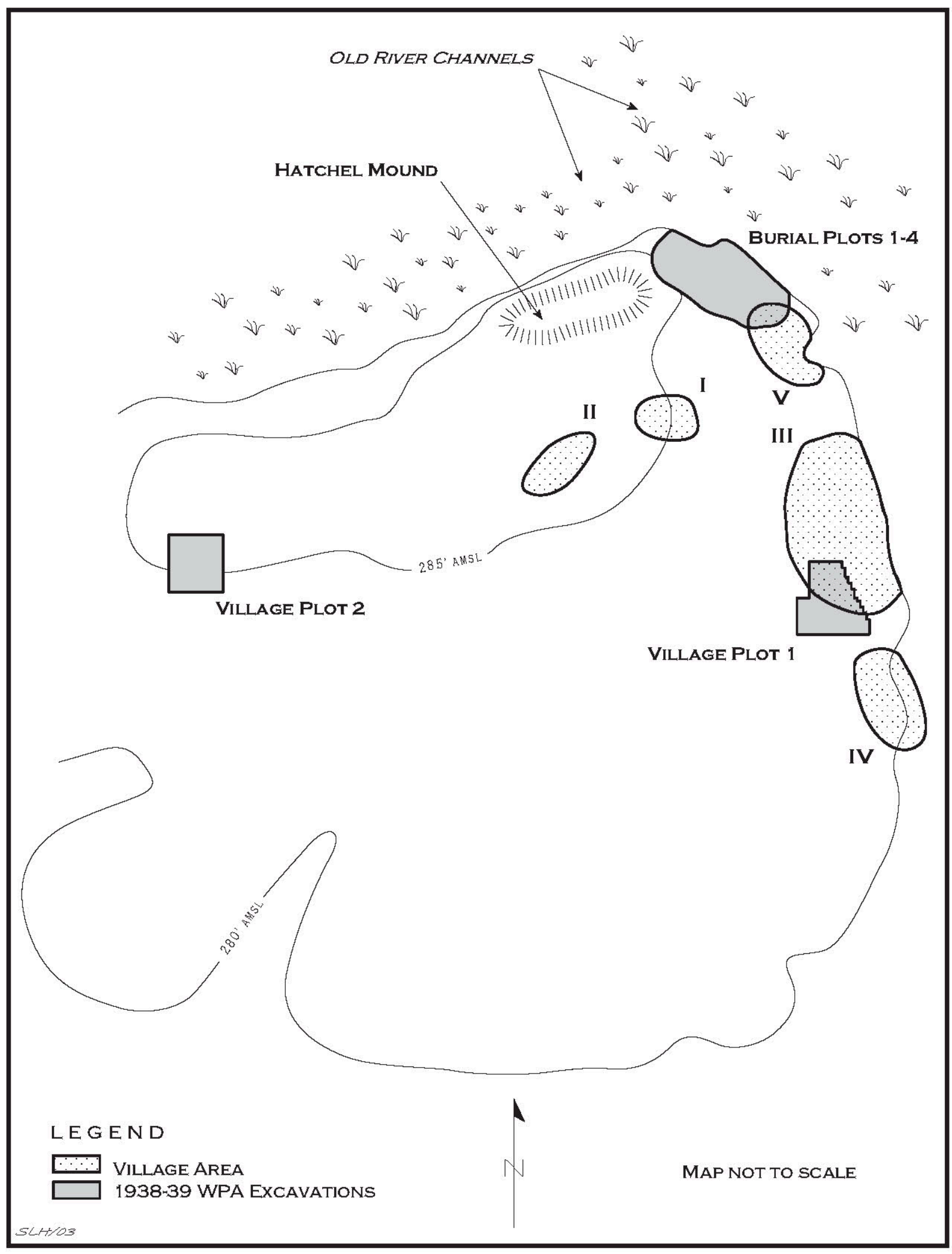

Figure 3. Village Plot 1 in Village Area III at the Hatchel site. 
one of the village areas at the Hatchel site can be characterized according to a suite of key technological attributes, as well as key decorative methods, motifs, and decorative elements. Each of these attributes identified on sherds analyzed in detail provides information about the technical knowledge and the stylistic choices specific to the ceramic tradition developed by Caddo potters living at the Hatchel site (and contemporaneous sites along the Red River in the upper Great Bend area, see Figure 2) and the raw materials components of the pottery making process. These in turn are informative about the different technical and stylistic choices made at various stages in that process. These differences provide a basis for future comparisons of the technological and stylistic variability of this specific ceramic assemblage to the technological and stylistic variability found in other ancestral Caddo ceramic assemblages and traditions in East Texas, as well as other regions in the southern Caddo area.

\section{Village Plot Excavations}

The 1939 WPA excavations in Village Plot 1 are about $350 \mathrm{~m}$ southeast of the platform mound at the Hatchel site (see Figure 3). At the time, the area was part of a large cultivated field (Figure 4).

Village Plot 1 was laid out in three sections that were each roughly 60 x $60 \mathrm{ft}$. blocks (Figure 5). They were then subdivided into a series of $5 \times 5 \mathrm{ft}$. squares. Each $5 \times 5 \mathrm{ft}$. square to either the right or the left of the zero baseline was labeled R1, R2, and so on or L1, L2, and so on, while the zero line was labeled in feet, normally beginning at zero; in the case of Village Plot 1, the zero begins at 30. Each $5 \times 5$ ft. unit was labeled with both an east-west and north-south designation (i.e., R5-60), with the southwest corner of the unit as the specific 5 x $5 \mathrm{ft}$. square provenience label. The Village Plot 1 excavations covered $10,725 \mathrm{ft}^{2}$, or approximately $991 \mathrm{~m}^{2}$. From north to south, the plot was $120 \mathrm{ft}(36.5 \mathrm{~m})$ long and it

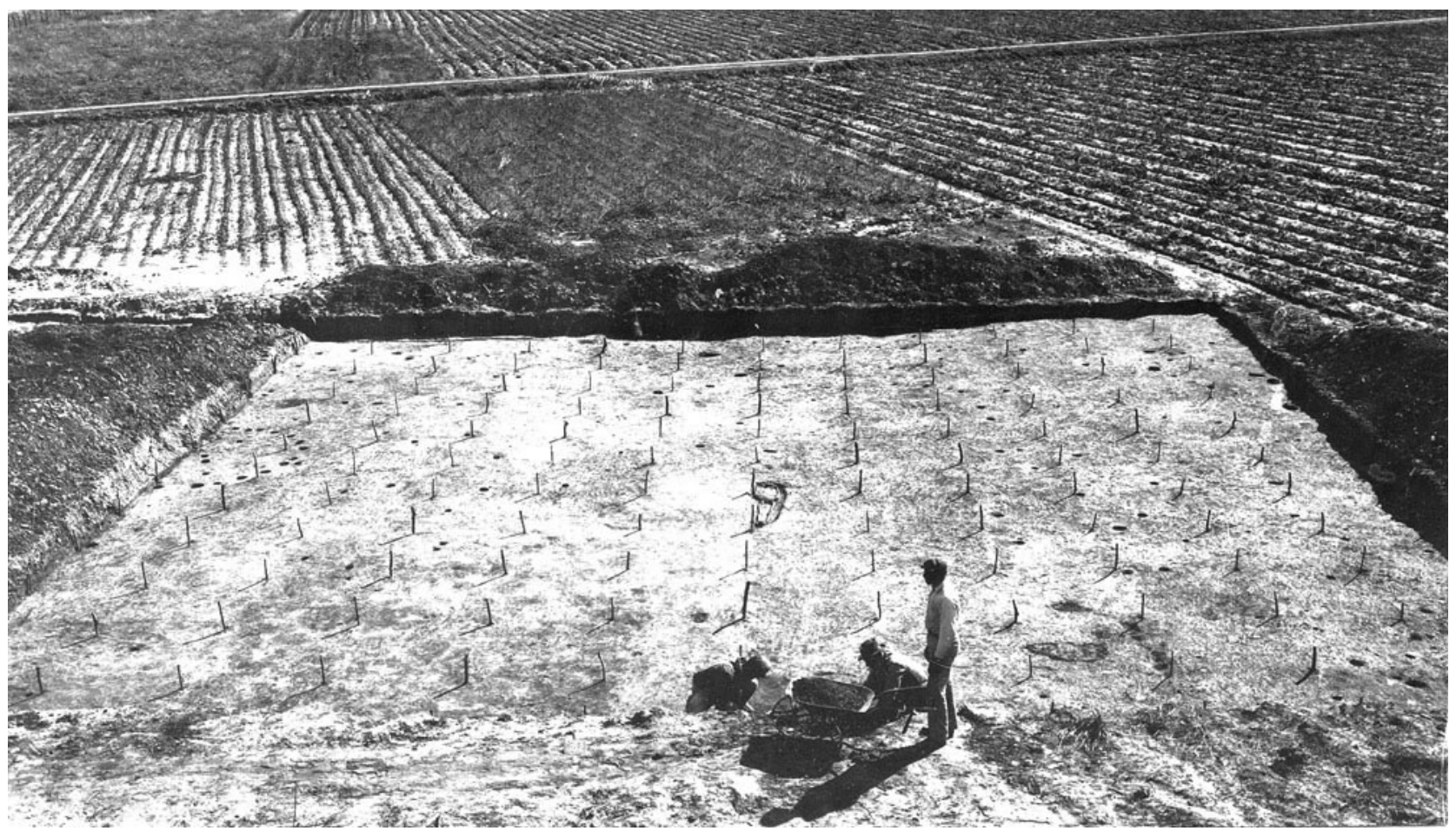

Figure 4. Village Plot 1 WPA excavations. Note Fea. 2 in left center of photograph. Image 41BW3-77, Texas Archeological Research Laboratory, The University of Texas at Austin. 


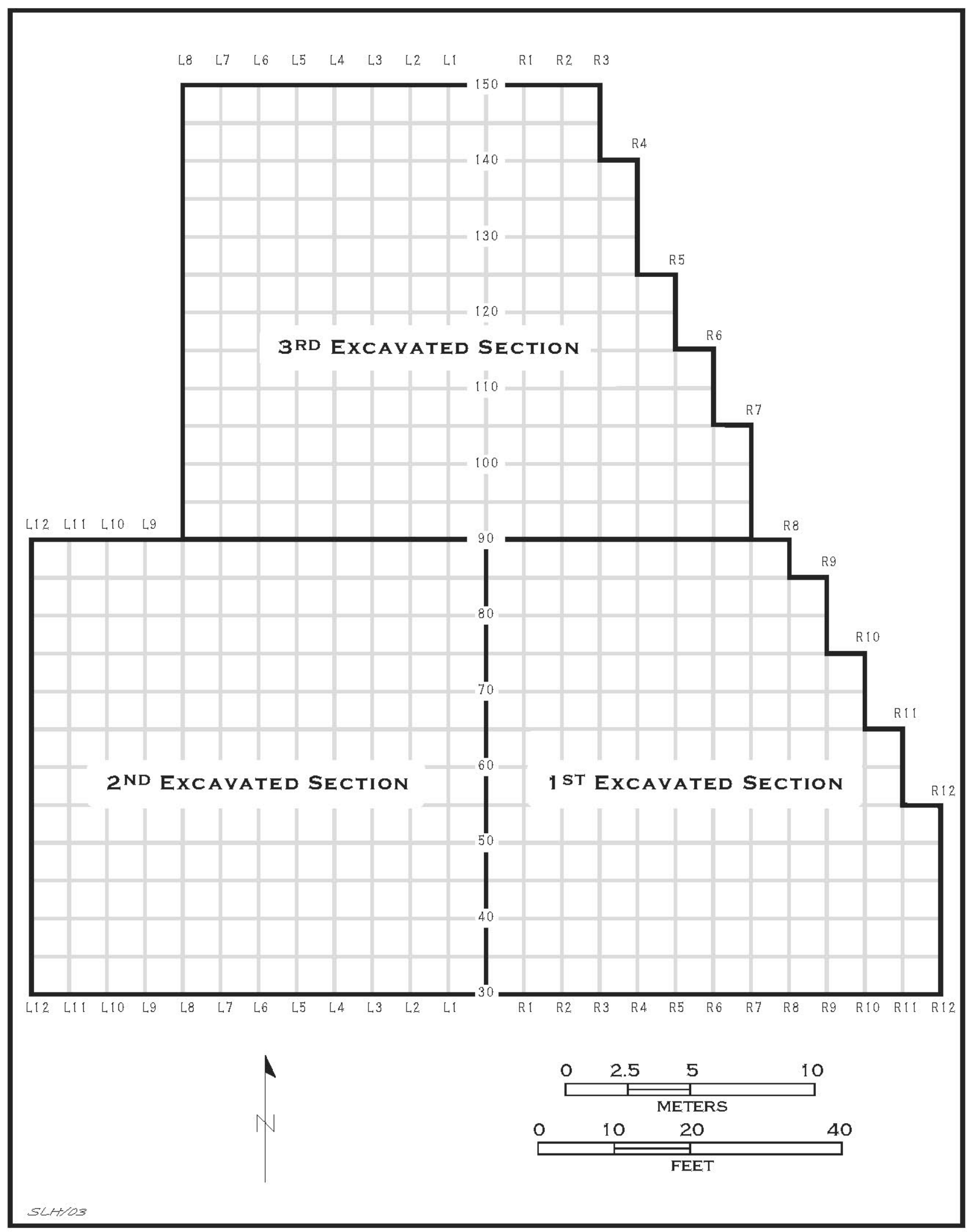

Figure 5. $1^{\text {st }}-3^{\text {rd }}$ excavated sections of Village Plot 1. 
was a maximum of $120 \mathrm{ft} .(36.5 \mathrm{~m})$ wide at its southern end and only $55 \mathrm{ft}$. $(16.8 \mathrm{~m})$ wide along the 150 line (see Figure 5).

Village Plot 1 had many features, including more than 300 post holes, six to nine small pit features, one large pit feature (F-3) filled with midden deposits, and three burials (Figure 6). A number of the post holes are associated with three circular domestic Caddo structures: F-1, F-2, and the large black charcoalstained area between 95-130 in the northern part of the village plot. F-1 appears to have been rebuilt twice (6.6 and $9.5 \mathrm{~m}$ in diameter), the northern structure (11 $\mathrm{m}$ in diameter) was only incompletely excavated by the WPA, and F-2, only $3.05 \mathrm{~m}$ in diameter, may have been a granary or elevated work platform (Figure 6).

\section{Methods of Sherd Analysis}

Ceramic style elements defined and recognized on sherds and vessels from a Caddo site simply represent one classification, among several developed and used over the years in Caddo archaeology of different ways of decorating a vessel by the prehistoric Caddo peoples. I think there is a general consensus that shared styles are "the result of direct cultural transmission once chance similarity in a context of limited possibilities is excluded" (Dunnell 1978:199). If the decorative elements are truly stylistic in character, then they allow the measurement of time as well as interaction between different but contemporaneous groups of people, along with an assessment of a potter's place within a larger tradition of ceramic practice. Because the lion's share of the ceramics from Caddo sites are sherds rather than vessels or sherd vessel groupings, and none of the vessels from Village Plot 1 and 2 at the Hatchel site are included in this study (but see Perttula 2005:Figure 11), the most accessible stylistic information from this village area at the site is the rim and body decorations (often different on the same vessel).

The stylistic analysis of Caddo ceramics from the Hatchel site focuses on the definition of recognizable decorative motifs and elements in the fine wares (i.e., the engraved and red-slipped vessels, including carinated bowls and bottles) and utility wares, usually cooking or storage jars and simple bowls. These wares are known to have been made and used differently, based on functional, technological, and stylistic analyses on numerous Caddo sherd assemblages in the broader East Texas region, with uses ranging from food service, cooking of food stuffs, as containers for liquids, and for plant food/seed crop storage. The ceramic analysis has been completed in conjunction with formal and technological analyses of a robust sample of plain and decorated rim and body sherds ( $n=419$ sherds, or $27 \%$ of the ceramic assemblage from Village Plot 1), emphasizing paste characteristics, non-plastic inclusions, surface treatments, and firing environments of the decorated and plain sherd assemblages (see Appendix 1).

One interest is in determining not only broad trends in changing ceramic styles in East Texas Caddo sites, but also in exploring more-fine-tuned synchronic and diachronic differences in stylistic composition and diversity in one area at the Hatchel site. Therefore, a more detailed consideration of ceramic stylistic variability and diversity focuses on decorative elements that can be identified on rim and body sherds. These represent distinct designs or design combinations (i.e., the breakdown of individual decorations within an overall design motif, as in a hatched triangle, circle, or tick marks) that can be identified on sherds and vessel sections (even if it is only a portion of the element), as a recurrent feature of decoration within each of the major decorative methods (e.g., incising, punctating, engraving, etc.) present in the Caddo ceramic assemblage. The design elements are defined at different levels of association, depending upon variations in the designs (e.g., the number and spacing of engraved lines on a rim), the location of the decoration (e.g., on the rim, body, on the vessel interior, etc.), and the method of decoration (e.g., horizontal vs. vertical brushing). 


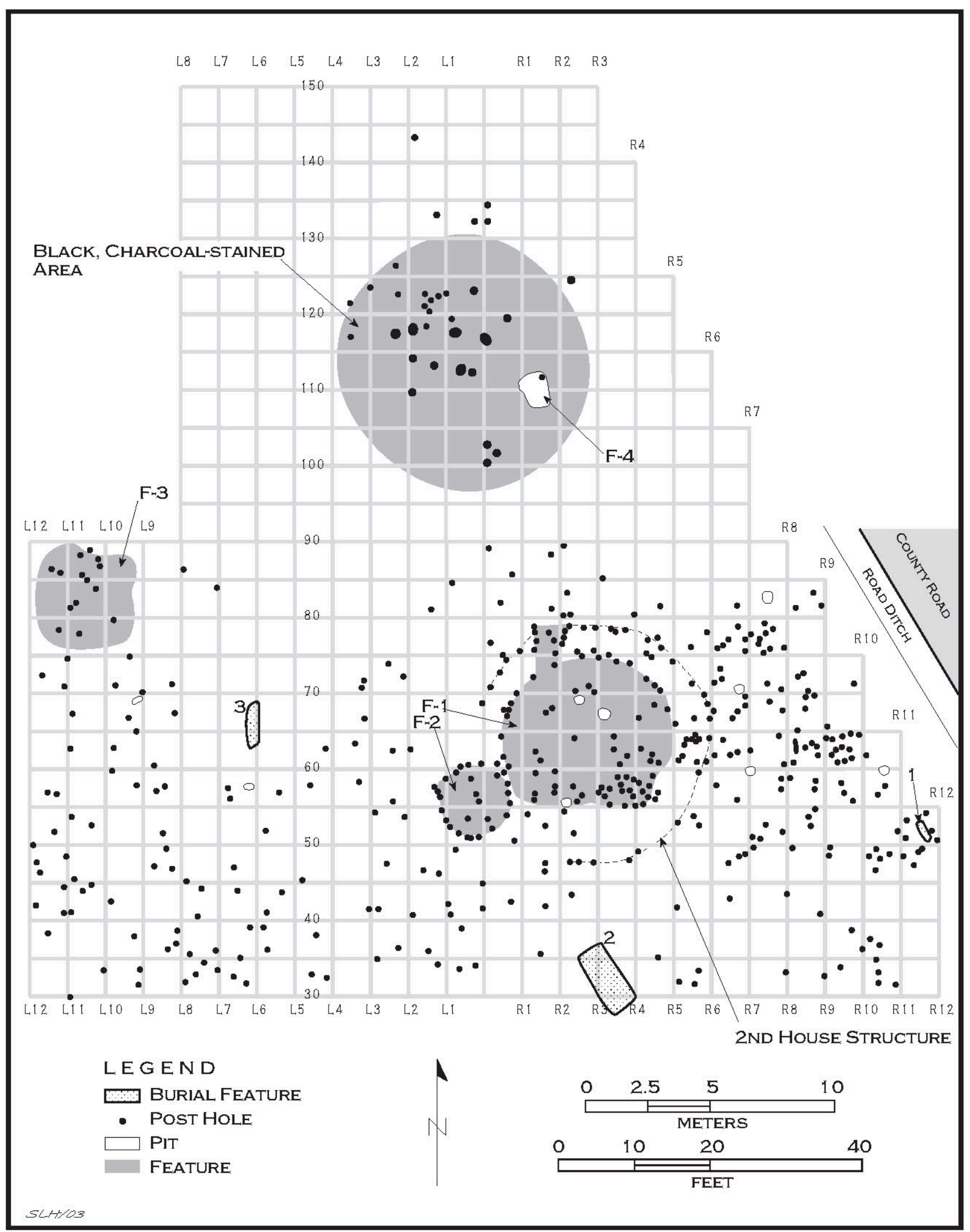

Figure 6. Village Plot 1 post holes and features. 
These same stylistic analyses can be employed to answer broader questions of the social and cultural affiliation of Caddo groups, and the place of the Hatchel site within a specific community of Caddo people, through stylistic and vessel morphological comparisons with collections from other broadly contemporaneous Caddo sites in the local area. We are also concerned with determining the character and frequency of the utility ware vessel forms in Caddo households and components, and how their composition at the assemblage level may be related to (and influenced by) the apparent intensification of maize consumption by Caddo groups in East Texas and the Southern Caddo area after ca. A.D. 1300/1400 (see Perttula 2008a; Wilson 2012; Wilson and Perttula 2013; Perttula et al. 2014), as well as differences in culinary and plant food storage traditions.

Utility ware vessels were used for cooking, storage, and probably other culinary activities; they tend to have a coarse paste, thick or thicker body walls, have smoothed interior surfaces, and are decorated with wet-paste designs (i.e., decorations were made with tools and fingers prior to the vessel being fired, when the vessel had a wet exterior surface). Fine wares are engraved, trailed, and red-slipped vessels that were used for food service and to hold liquids, as well as for other purposes (i.e., effigy vessels). They tend to have fine pastes, with finely crushed tempers, are frequently burnished on interior and/or exterior vessel surfaces (except the bottles, which were burnished on exterior surfaces only), and have relatively thin body walls compared to the utility wares. The engraved decorations are etched into the exterior vessel surface after the vessel has been fired or was leather-hard.

Sherds recovered from Village Plot 1 at the Hatchel site are characterized according to a suite of key technological attributes, as well as key decorative methods, motifs, and decorative elements (see Appendix 1). Each of these attributes provides information about the technical knowledge and the stylistic choices specific to the ceramic tradition(s) present at the site and the raw materials components of the pottery making process, which in turn is informative about the different technical and stylistic choices made at various stages in that process. These differences, in turn, provide a basis for comparing the technological and stylistic variability of this specific ceramic assemblage to the technological and stylistic variability found in other contemporaneous Caddo ceramic assemblages in this part of East Texas.

Following the CTA Ceramic Protocol for East Texas ceramics (see Perttula 2010), the detailed analysis of the decorated and plain ceramic sherds from the Hatchel site (Appendix 1) is based on differences in temper, type of sherd (i.e., rim, body, or base), rim and lip form (cf. Brown 1996:Figure 2-12), decoration (if present), surface treatment (smoothing, burnishing, or polishing; see Rice 1987), and firing conditions (cf. Teltser 1993). Sherd cross-sections were inspected macroscopically and with a 10X hand lens to determine the character of the paste and its inclusions. Determining the firing conditions is based on the identification of the firing core in the sherd cross-sections and the identification of oxidation patterns as defined in Teltser (1993:535-536 and Figure 2a-h).

More specifically, the following attributes were employed in the analysis of the ceramics from the Hatchel site: (a) temper, the deliberate and indeterminate materials found in the paste (Rice 1987:411), including a variety of tempers (grog or crushed sherds, burned bone, and hematite) and "particulate matters of some size;" (b) although most of the sherds are small and thus from indeterminate vessel forms, where sherds were large enough, vessel form categories that could be identified include open containers (bowls and carinated bowls) and restricted containers, including jars and bottles. Other form attributes include rim profile (outflaring or everted, direct or vertical, and inverted) and lip profile (rounded, flat, or folded to the exterior, among others). Observations on ceramic sherd cross-sections permit consideration of oxidation patterns (Teltser 1993:Figure 2), namely the conditions under which a vessel was fired and then cooled after firing. Finally, wall thickness was recorded in millimeters ( $\mathrm{mm}$ ), using a vernier caliper, along the mid-section of the sherd. 
With respect to interior and exterior surface treatment on the sherds, the primary methods of finishing the surface of Caddo vessels includes smoothing, burnishing, and polishing, although a few sherds may still have scraping marks from initial surface treatment work by the potter. Brushing, a popular method of roughening the surface of Middle, Late, and Historic Caddo cooking jars in this part of the Red River basin with stiff bundles of grasses, is considered a decorative treatment here rather than solely a functional surface treatment (cf. Rice 1987:138). A roughened and brushed pot would certainly have been easier to pick up and carry than would an unroughened or smoothed vessel, but because the brushing was applied to be an integral part of the decoration of both rim and body vessel surface, I de-emphasize it as a surface treatment. Smoothing creates "a finer and more regular surface... [and] has a matte rather than a lustrous surface" (Rice 1987:138). Burnishing creates an irregular lustrous finish marked by parallel facets left by the burnishing tool (perhaps a smoothed pebble or bone). A polished surface treatment is marked by a uniform and highly lustrous surface finish, done when the vessel is dry, but without "the pronounced parallel facets produced by burnishing leather-hard clay" (Rice 1987:138).

The application of a hematite-rich clay slip, black after firing in a reducing environment, is another form of surface treatment noted in this assemblage, although it is not common. The clay slip was typically applied to the vessel exterior or both surfaces, and then was burnished or polished after it was leatherhard or dry; when the vessel was fired, it created a thin red slip. In other instances, a kaolin-rich clay (i.e., white pigment) or a hematite-rich clay (i.e., red pigment) may be applied as a pigment to the decoration on engraved ceramic vessels.

Besides sherds with a red slip, decorative techniques present in the Hatchel site ceramic sherd collections include engraving, trailing, incising, punctation, brushing, neck banded, and appliqué, and on certain sherds, combinations of decorative techniques (i.e., brushed-incised and brushed-appliqued, or incised-punctated sherds) created the decorative elements and motifs, with one motif on the rim and another on the vessel body (Schambach's Rule of Two). Engraving and the excising of punctations on fine wares was done with a sharp tool when the vessel was either leather-hard or after it was fired, while the other decorative techniques were executed with tools or fingers (incising, trailing, punctations, and pinching with wood or bone sticks or dowels), by adding strips of clay to the wet body (appliqué), using frayed sticks or grass stems (brushing) across the vessel surface, or corrugating vessel coils when the vessel was wet or still plastic to create a series of neck bands. Excising is considered a form of engraved decoration, where the clay is deliberately and closely marked/scraped and carved away with a sharp tool, usually to create triangular elements or crescent-shaped elements separating or defining scrolls. A red clay film or wash may be added to the surface (interior and/or exterior surfaces) of some vessels as a slip (or a coating) before they were fired.

\section{Plain Sherds}

The 1218 plain sherds from the Village Plot 1 area include rim, body, and base sherds as well as one strap handle to a jar (Table 1). As there are a total of 63 plain, utility, and fine ware rim sherds in the assemblage, the fact that $43 \%$ of the rims are plain suggests that plain wares (or that the rims come from decorated vessels that may have had limited decorations themselves) are a significant component of the Village Plot 1 ceramics at the Hatchel site. Fine ware rims $(n=24)$ comprise $38 \%$ of the rims, while the remaining $19 \%$ are rims from utility ware vessels $(n=12)$. 
Table 1. Plain sherds from Village Plot 1 at the Hatchel site.

\begin{tabular}{lrr}
\hline Sherd type & $\mathrm{N}$ & Percent \\
\hline rim & 27 & 2.2 \\
body & 1123 & 92.2 \\
base & 67 & 5.5 \\
strap handle & 1 & 0.1 \\
Totals & 1218 & 100.0 \\
\hline
\end{tabular}

All three wares in the Village Plot 1 ceramic assemblages are predominantly tempered with grog or crushed sherds (Table 2), although there are a number of temper classes represented in the detailed sherd sample. Sherds with grog temper comprise between $60.8-65.5 \%$ of the sherds in the three wares, with the highest proportions amongst the utility wares. Including sherds that have a combination of temper inclusions, more than $97 \%$ of the analyzed sherds have grog in the paste.

Table 2. Temper use in the plain, utility, and fine wares.

\begin{tabular}{|c|c|c|c|c|}
\hline Temper class & $\begin{array}{l}\text { Plain } \\
\text { ware }\end{array}$ & $\begin{array}{l}\text { Utility } \\
\text { ware }\end{array}$ & $\begin{array}{l}\text { Fine } \\
\text { ware }\end{array}$ & Percent \\
\hline Bone & $0.9 *$ & - & 3.1 & 1.2 \\
\hline Bone-hematite & - & 1.0 & - & 0.2 \\
\hline Grog & 65.5 & 66.7 & 60.8 & 64.7 \\
\hline Grog/Sandy paste & 5.4 & 8.1 & 8.2 & 6.7 \\
\hline Grog-bone & 9.4 & 9.1 & 3.1 & 7.9 \\
\hline Grog-bone-hematite & 1.3 & - & - & 0.7 \\
\hline $\begin{array}{l}\text { Grog-bone-hematite- } \\
\text { organics }\end{array}$ & - & - & 1.0 & 0.2 \\
\hline Grog-bone-organics & 0.4 & 1.0 & 2.1 & 1.0 \\
\hline Grog-bone/Sandy paste & 0.4 & - & - & 0.2 \\
\hline Grog-hematite & 3.1 & 7.1 & 6.2 & 4.8 \\
\hline Grog-hematite-organics & 0.4 & - & 2.1 & 0.7 \\
\hline Grog-hematite/Sandy paste & - & 1.0 & 1.0 & 0.5 \\
\hline Grog-organics & 7.6 & 3.0 & 12.4 & 7.6 \\
\hline Grog-organics/Sandy paste & 0.4 & 2.0 & - & 0.7 \\
\hline Shell & 1.8 & 1.0 & - & 1.2 \\
\hline Shell-grog & 1.8 & - & - & 1.0 \\
\hline Shell-grog-bone & 0.4 & - & - & 0.2 \\
\hline
\end{tabular}


Table 2. Temper use in the plain, utility, and fine wares, cont.

\begin{tabular}{lllll}
\hline Temper class & $\begin{array}{l}\text { Plain } \\
\text { ware }\end{array}$ & $\begin{array}{l}\text { Utility } \\
\text { ware }\end{array}$ & $\begin{array}{l}\text { Fine } \\
\text { ware }\end{array}$ & Percent \\
\hline Proportion of sherds with: & $97.3 \%$ & $98.0 \%$ & $97.0 \%$ & $97.4 \%$ \\
Grog & $13.5 \%$ & $11.1 \%$ & $9.3 \%$ & $11.4 \%$ \\
Bone & $4.9 \%$ & $9.1 \%$ & $10.3 \%$ & $7.1 \%$ \\
Hematite & $8.9 \%$ & $6.1 \%$ & $17.5 \%$ & $10.2 \%$ \\
Organics & $4.0 \%$ & $1.0 \%$ & - & $2.4 \%$ \\
Shell & $6.3 \%$ & $11.1 \%$ & $9.3 \%$ & $8.1 \%$ \\
Sandy paste & 223 & 99 & 97 & 419 \\
\hline Total sherds & & & & \\
\hline
\end{tabular}

*percentage

Sherds from bone-tempered vessels are most common in the fine wares, but overall, the highest proportions of bone temper use (either as the sole temper or in combination with other tempers) is in the plain wares (13.5\%, see Table 2). Crushed hematite temper is never the sole temper inclusion in the Village Plot 1 sherds, occurring in combination with grog, bone, or organics. Hematite was used most often in the utility wares and fine wares.

The frequency of sherds with organics in the paste is considerable in the Village Plot 1 sherds (see Table 2), particularly amongst the fine wares. The organics in the paste are not temper per se, but pieces of organics that remained in the clay that were not totally combusted when vessels were fired. Perhaps the overall frequency of organics in the paste of the three wares also represents differences in the amount of time the Caddo potters spent in processing and preparing the alluvial clays used in vessel manufacture.

The moderate amount of sherds that are from vessels with a sandy paste $-8.1 \%$ of the assemblage as a whole (see Table 2) - suggests that not only did some Caddo potters prefer a naturally sandy clay for vessel manufacture, but that at least two or more sources of alluvial clays were employed by the potters that lived in Village Plot 1.

Finally, a few sherds (1.2\%) from plain and utility ware vessels made elsewhere on the Red River (either by McCurtain or Belcher phase potters) are from shell-tempered vessels. A similar percentage have shell with grog and/or bone temper added to the paste. Such temper mixtures were likely common in Late Caddo period ceramic assemblages in the southern Caddo area (e.g., Perttula et al. 2012:257, 260).

The majority of the sherds in Village Plot 1 are from vessels that were fired in a low oxygen or reducing environment (Table 3), probably smothered in a bed of coals or other fuels. This is especially the case for the fine wares, where $91.6 \%$ of the sherds are from vessels that were fired in this manner; this left vessels with dark gray to black surface and core colors. The majority of the reduced fired vessels were subsequently pulled from the fire and allowed to cool in the open air; this cooling led to the formation of thin oxidized areas along either one or both sides of the vessel surface. Sherds from vessels fired in a high oxygen or oxidized environment were most common in the plain wares and utility wares, as were sherds from vessels that were incompletely oxidized during firing (Table 3). 
Table 3. Firing conditions in the plain, utility, and fine wares in Village Plot 1 at the Hatchel site.

\begin{tabular}{lccc}
\hline Firing Condition & Plain ware & Utility ware & Fine ware \\
\hline Oxidized (A) & $16.6^{*}$ & 13.7 & 3.2 \\
Incompletely oxidized (C-E) & 17.5 & 13.7 & - \\
Reduced (B) & 18.8 & 19.6 & 36.8 \\
Reduced, and cooled in & 40.8 & 52.0 & 54.8 \\
$\quad$ the open air (F-H) & 6.3 & 1.0 & 5.4 \\
Sooted and/or smudged (I-L) & & \multicolumn{2}{c}{} \\
\hline
\end{tabular}

*percentage. Note that firing conditions follow Teltser (1993:Figure 2a-h) and Perttula (2005:Figure 5-30a-l)

Vessels that were deliberately smudged or sooted represent between 5.4-6.3\% of the sherds in the fine wares and plain wares, respectively (see Table 3 ). This left a noticeable but thin black layer atop either the interior or exterior vessel surface, typically on bottles and carinated bowls.

There are significant differences between the three wares in the surface treatment different vessels received after they were manufactured. Plain wares are almost exclusively smoothed, either on one or both vessel surfaces (Table 4). Utility wares are regularly smoothed only on their interior surfaces. Fine wares, on the other hand, were regularly smoothed on both vessel surfaces, and a significant proportion of the sherds were burnished on one or both surfaces; these are most commonly from bottles and carinated bowls.

Table 4. Surface treatment of plain, utility, and fine ware sherds in Village Plot 1.

\begin{tabular}{lccc}
\hline Surface treatment & Plain ware & Utility ware & Fine ware \\
\hline Exterior smoothed & $34.9^{*}$ & 2.0 & 29.9 \\
Interior smoothed & 29.6 & 31.3 & 20.6 \\
Exterior burnished & 2.2 & - & 14.4 \\
Interior burnished & - & 1.0 & 4.1 \\
\hline
\end{tabular}

*percentage

There are differences in vessel wall thickness between the three wares, based on mean, median, and mode values of rim and body sherds (see Van Pool and Leonard 2011:45-47); base sherds range from 7.0-15.3 mm in thickness, but most of them are more than $10.0 \mathrm{~mm}$ in thickness (see Appendix 1). The vessel walls (rim and body) of the fine wares have a mean thickness of $6.91 \mathrm{~mm}$, with a data range from 4.4-9.8 mm (Figure 7). Their median thickness is $6.8 \mathrm{~mm}$; the mode is $6.5 \mathrm{~mm}$. Plain wares are intermediate in thickness, with a mean of $7.05 \mathrm{~mm}$, a median thickness of $7.2 \mathrm{~mm}$, and the mode is $6.5 \mathrm{~mm}$. Utility wares have the thickest vessel walls - but only about 5-8\% thicker than either the plain wares or the fine wares in Village Plot 1-with a mean of $7.42 \mathrm{~mm}$, a median thickness of $7.3 \mathrm{~mm}$, and the mode is $7.0 \mathrm{~mm}$ (see Figure 7).

\section{Decorated Sherds}

The 332 decorated sherds from the Village Plot 1 area at the Hatchel site include both utility wares $(46.7 \%)$ and fine wares $(53.3 \%)$ (Table 5). The high frequency of sherds from fine ware vessels is particularly notable; however, similar proportions of fine ware sherds have been documented in the other WPA village and burial plot excavations as well as Village Areas I and Village Areas III-V (see Perttula and Nelson 2003). 


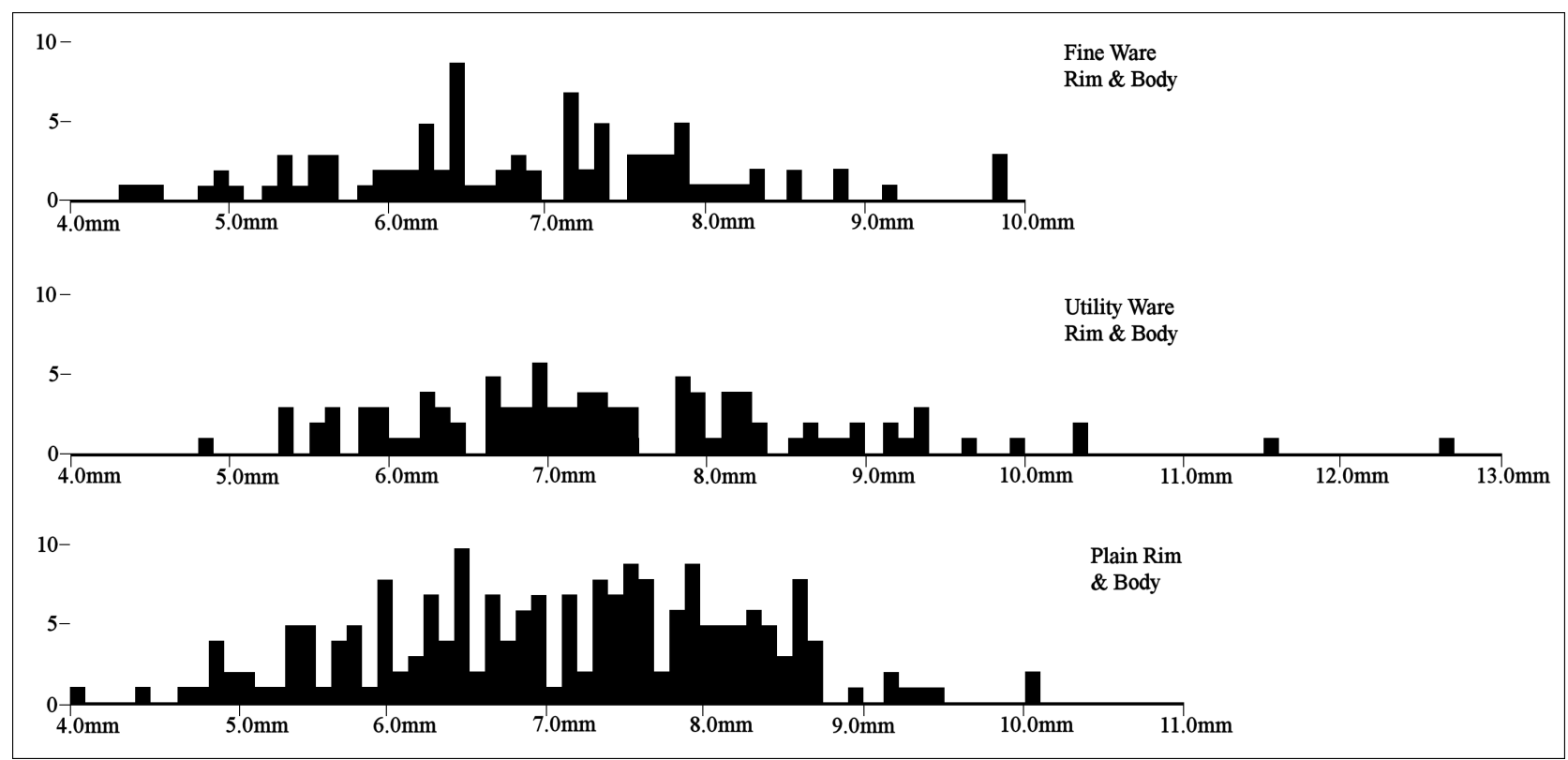

Figure 7. Rim and body wall thickness in the plain, utility, and fine ware sherds in Village Plot 1 at the Hatchel site.

Table 5. Methods of decoration of sherds in Village Plot 1 at the Hatchel site.

Decorative Method

Utility Ware

Appliqued

Appliqued-brushed

Brushed

Brushed-incised

Incised

Incised-Punctated

Neck banded

Neck banded-punctated

Punctated

Trailed-incised

Subtotal
39

2

26

5

51

4

5

1

20

2

155
Percent

11.8

0.6

7.8

1.5

15.4

1.2

1.5

0.3

6.0

0.6

46.7

Fine Ware

Engraved

Engraved-punctated

Red-slipped

Trailed

Subtotal 
The utility wares include 12 rims and 143 body sherds: sherds with incised, appliqued, brushed, and punctated elements are the principal decorated methods represented in Village Plot 1; these account for $88 \%$ of the utility wares (see Table 5). The rims are from neck banded ( $\mathrm{n}=1$, Nash Neck Banded), punctated $(n=6)$, incised $(n=3$, Foster Trailed-Incised), incised-punctated $(n=1)$, and appliqued vessels $(n=1)$. The one appliqued rim - with a rim peak and shell-tempered - is from a McKinney Plain jar (Suhm and Jelks 1962:Plate 49j). It is likely a trade vessel made by a mid-Red River McCurtain phase Caddo potter. Based on the decorative elements on the rims, the punctated rim sherds may be from Cass Appliqued, Foster Trailed-Incised, and Nash Neck Banded jars, as well as what Suhm and Jelks (1962:Plate 791-m) label as Miscellaneous Utility Pottery.

There are a number of distinctive and significant decorative elements identified in the utility wares from Village Plot 1. First, these include McKinney Plain jars with parallel appliqued ridges and nodes on vessel bodies as well as vertical appliqued ridges on the rim (Table 6). The appliqued-brushed sherds may also be from McKinney Plain vessels (see Suhm and Jelks 1962:97). Brushed and brushed-incised sherds are from short-rimmed Karnack Brushed-Incised vessels (probably Karnack Brushed-Incised, var. Karnack, see Schambach and Miller 1984:123), while the distinctive incised sherds in the assemblage are from varieties of Foster Trailed-Incised (Figure 8a, c-d, f). These appear to be from Foster Trailed-Incised, var. Red Lake, a $16^{\text {th }}$ century utility ware (Schambach and Miller 1984:121 and Table 11-12). There are Pease Brushed-Incised sherds in the Village Plot 1 assemblage as well (Figure 8b).

Table 6. Significant decorative elements in the Village Plot 1 utility wares.

Decorative method

Appliqued

Appliqued

Appliqued

Appliqued-brushed

Brushed and Brushed-incised

Incised

Incised

Incised

Incised-Punctated
Decorative element

multiple parallel appliqued ridges on body

parallel appliqued ridges and appliqued node (McKinney Plain)

vertical appliqued ridges (McKinney Plain jar with rim peak; shell-tempered)

parallel brushing marks between narrow appliqued ridges on body

parallel brushing marks or brushed-incised marks and lines on vessel body (Karnack Brushed-Incised)

horizontal (broad line, trailed) and diagonal opposed incised lines on the rim (Foster Trailed Incised)

vertical incised line with diagonal opposed incised lines (Foster Trailed-Incised or cf. Pease Brushed-Incised)

sets of parallel, broad, incised lines

horizontal and curvilinear broad incised lines on the body and row of tool punctates at rim-body juncture (Foster Trailed-Incised) 
Table 6. Significant decorative elements in the Village Plot 1 utility wares, cont.

\begin{tabular}{ll} 
Decorative method & Decorative element \\
\hline Incised-Punctated & $\begin{array}{l}\text { tool punctated row at lip and mid-rim, with sets of } \\
\text { diagonal opposed incised lines between the punctated rows } \\
\text { (Sanson Incised) }\end{array}$ \\
Neck banded & horizontal neck bands on the rim (Nash Neck Banded) \\
Punctated & rows of tool punctates on the rim \\
\hline
\end{tabular}

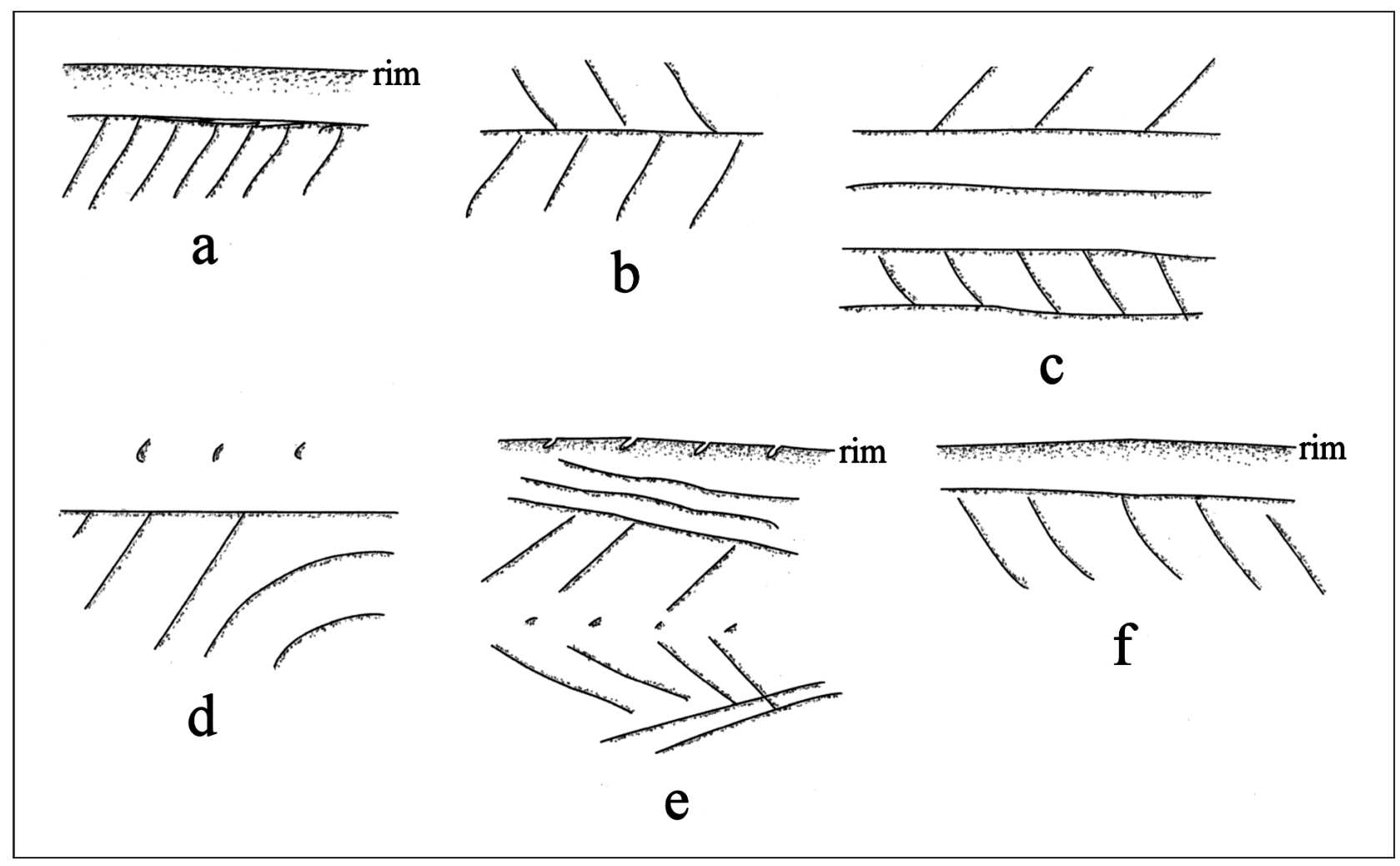

Figure 8. Selected decorative elements on utility ware sherds from Village Plot 1: a, c-d, f, Foster Trailed-Incised; b, cf. Pease Brushed-Incised; e, possible Sanson Incised.

Several distinctive incised-punctated sherds in Village Plot 1 are from Foster Trailed-Incised vessels (see Table 6), but one (see Figure 8e) resembles the decoration on Sanson Incised, a ceramic type most abundant on Plaquemine culture sites of east central Louisiana (Kelley 1997:54). The neck banded sherds are from the non-shell-tempered variety of Nash Neck Banded that is characteristic of Texarkana phase sites along the upper Great Bend region of the Red River; upstream in the middle Red, in the McCurtain phase area, Nash Neck Banded vessels are shell-tempered.

The fine wares in Village Plot 1 include 24 rim sherds and 153 body sherds. About $51 \%$ of the fine ware sherds are from vessels with engraved decorative elements, and another $36 \%$ fine ware sherds have 
trailed decorative elements (Table 7). About $9 \%$ of the fine ware sherds are red-slipped only; since there are no red-slipped rims, it is not certain that the red-slipped sherds are from vessels decorated solely with a slip, or are the undecorated portions of engraved or engraved-punctated vessels.

Table 7. Significant decorative elements in the Village Plot 1 fine wares.

Decorative method Decorative element

Engraved

Engraved

Engraved

Engraved

Engraved

Engraved

Engraved

Engraved

Engraved

Engraved-punctated

Engraved-punctated

Engraved-punctated

Engraved-punctated

Trailed

Trailed sets of horizontal engraved lines on rim panel

narrow hatched or cross-hatched engraved zones on bottle bodies

row of engraved dashes (Barkman Engraved) on rim panel

horizontal engraved lines with diagonal ticks and vertical dashed lines (Barkman Engraved)

opposed sets of curvilinear and diagonal engraved lines (cf. Hatchel Engraved)

cross-hatched engraved zones and negative ovals and/or concentric circles (Hodges Engraved)

sets of horizontal engraved lines with tick marks, on rim panel

(Simms Engraved)

slanted scroll element with curvilinear scroll dividers, on short rim panel (Simms Engraved)

horizontal engraved lines and slanted scrolls on short rim panel, with curvilinear brackets in scroll fill zone (Simms Engraved)

horizontal engraved lines and zone filled with row of excised punctates or linear punctates; on carinated bowl rim panel (Barkman Engraved)

horizontal engraved lines and horizontal scroll, with curvilinear scroll dividers, and rows of excised punctates between and below scroll lines (Barkman Engraved)

horizontal and curvilinear engraved lines and narrow horizontal and curvilinear engraved zones filled with excised punctates (Barkman Engraved)

engraved panels on short rims divided by single vertical lines; panels have small pendant tick marks and central row of excised punctates (Simms Engraved)

diagonal trailed lines on the rim (Keno Trailed)

sets of curvilinear and opposed curvilinear trailed lines on bowl and bottle bodies (Keno Trailed) 
One fine ware rim is trailed (Keno Trailed) (Figure 9c), 21 have engraved designs (Figure 9g, 1), and two rims have engraved-punctated elements (Figure 9m). These engraved-punctated rims are from Barkman Engraved and Simms Engraved (Figure 9m) carinated bowls.

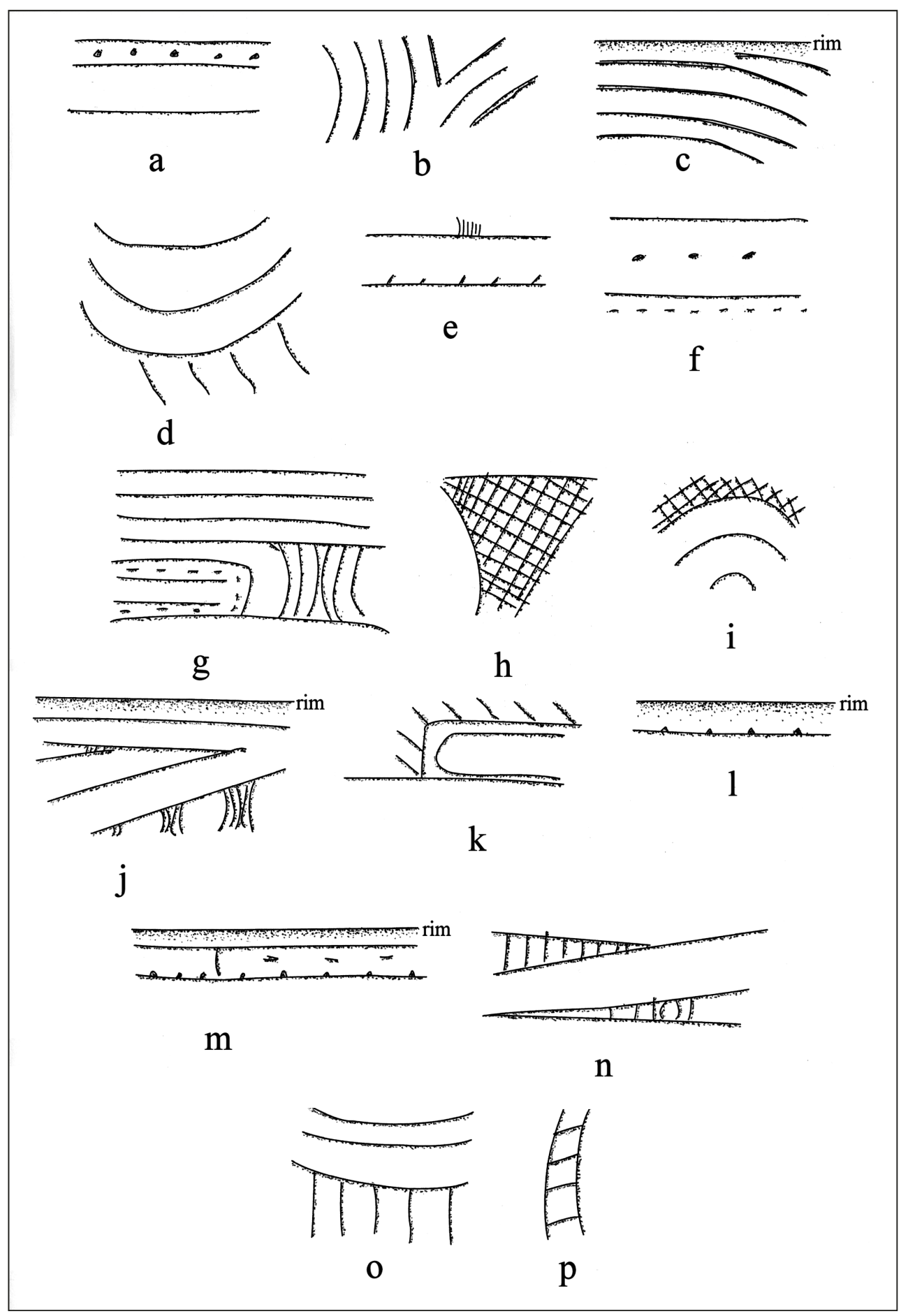

Figure 9. Engraved, engraved-punctated, and trailed decorative elements on Village Plot 1 fine ware sherds: a, f-g, m, engraved-punctated; b-c, trailed; d-e, h-l, n-p, engraved. 
There are Keno Trailed bottle body sherds in the Village Plot 1 assemblage (see Figure 9b), and various curvilinear, hatched, and hatched decorative elements from engraved bottles of the Hatchel Engraved and Hodges Engraved types (see Figure 9d, h-i, o-p). Distinctive short-rimmed Simms Engraved rim sherds have lower rows of small excised triangles and tick marks in horizontal panels (see Figure 9e, 1-m). Barkman Engraved vessels have horizontal lines as well as horizontal and rectilinear bands, sometimes filled with small excised punctations (see Figure 9a, f), divided by vertical bracket elements (see Figure 9g). One Barkman Engraved vessel sherd has a curvilinear engraved element in a narrow panel surrounded by a diagonal hatched zone (see Figure 9k). The fine ware vessel sherds from Village Plot 1 also have slanting scroll elements (see Figure 9j, n). These may be from Avery Engraved vessels (see Suhm and Jelks 1962:Plate 21) or Taylor Engraved vessels (see Suhm and Jelks 1962:Plate 75).

The same range of utility ware and fine ware decorative elements and identified types are present in other parts of the Hatchel village that have been excavated, including Village Plot 2 and Burial Plots 1-4 (see Figure 3). This includes Emory Punctated-Incised jar sherds (Figure 10e), as well as sherds from Foster Trailed-Incised (Figure 11a, e) vessels, and various curvilinear-rectilinear punctated-filled incised zones on jars (Figures $10 \mathrm{f}$ and $11 \mathrm{~b}, \mathrm{k}$ ).

The fine wares from other excavated areas at the Hatchel site are as diverse as the assemblage from Village Plot 1; the sherds represented suggest that the domestic deposits in these various excavated areas are contemporaneous. The fine wares include sherds from Simms Engraved carinated bowls (see Figures 10a and 11f, i), engraved and engraved-punctated Barkman Engraved carinated bowls (see Figures 10g and 11g-h, j, 1), and Avery Engraved carinated and compound bowls (see Figures 10b-c and 11c), as well as Hatchel Engraved (see Figure 10h-i) and Belcher Engraved (see Figure 10d) bottle sherds. Sherds from carinated bowls with scrolls and hatched fill zones are present in the Burial Plots excavations (see Figure 11d), along with a rim sherd from a Hodges Engraved carinated bowl (see Figure 11m).

\section{Likely Age of the Ceramic Sherd Assemblage}

There are two radiocarbon dates from Village Areas III and V at the Hatchel site. Based on the recovered decorated sherds from these areas (see Perttula and Nelson 2003), and their stylistic comparability to the Village Plot 1 decorated sherds, these dates provide what appears to be a reasonable temporal range for the Village Plot 1 ceramic assemblage. At two sigma the calibrated age ranges are A.D. 1460-1660 and A.D. 1470-1660 (Perttula 2005:Table 2). It may be that the latter part of that age range (i.e., after ca. A.D. 1550) is most pertinent, given the common occurrence of Keno Trailed bottle and bowl sherds as well as several sherds from Simms Engraved and Hodges Engraved vessels, known to occur in the latter part of the Texarkana and Belcher phase sites along the Red River. Recent calibrated two sigma radiocarbon dates from two Belcher phase houses in Mound B (Houses 1 and 2) at the Belcher site (16CD13) are A.D. 1510-1660 and A.D. 1440-1620 (Jeffrey S. Girard, June 2013 personal communication). They corroborate the estimated age of the Village Plot 1 Nasoni Caddo occupation, as does Kelley's (2012:412) observation that the Belcher phase - very much contemporaneous with the principal occupation at the Hatchel site-dates from ca. A.D. 1500-1700.

Certainly a key to establishing a more refined age of the Nasoni Caddo occupation in Village Plot 1 is obtaining a new and robust series of radiocarbon dates from organic remains preserved in feature deposits being curated at TARL. With these dates in hand, one can complete a Bayesian analysis of all the village radiocarbon dates (cf. Selden and Perttula 2013a, 2013b). 


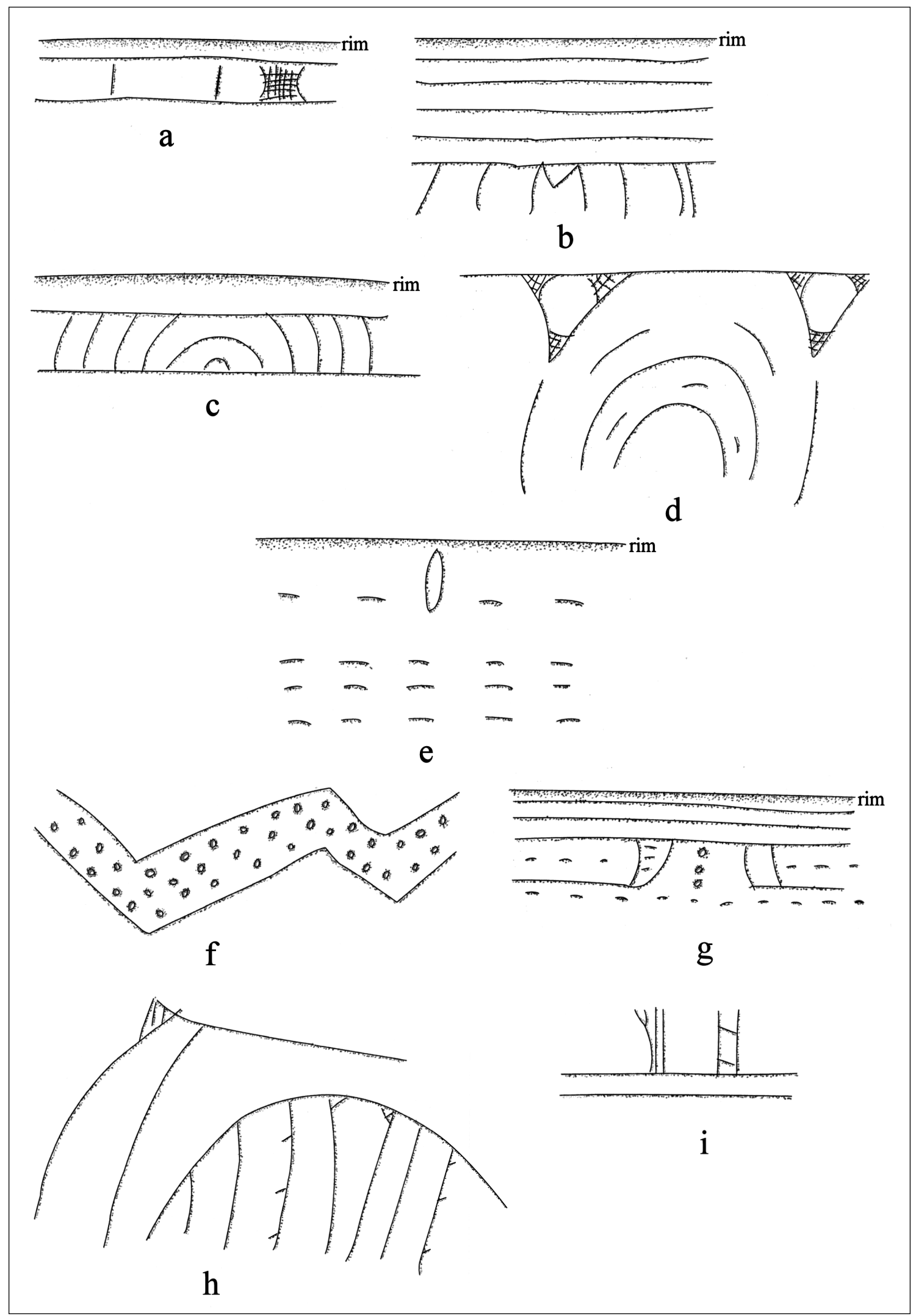

Figure 10. Decorative elements on selected fine ware and utility ware sherds from Village Plot 2 excavations: a-d, g-i, engraved; e, punctated-appliqued; f, incised-punctated. 


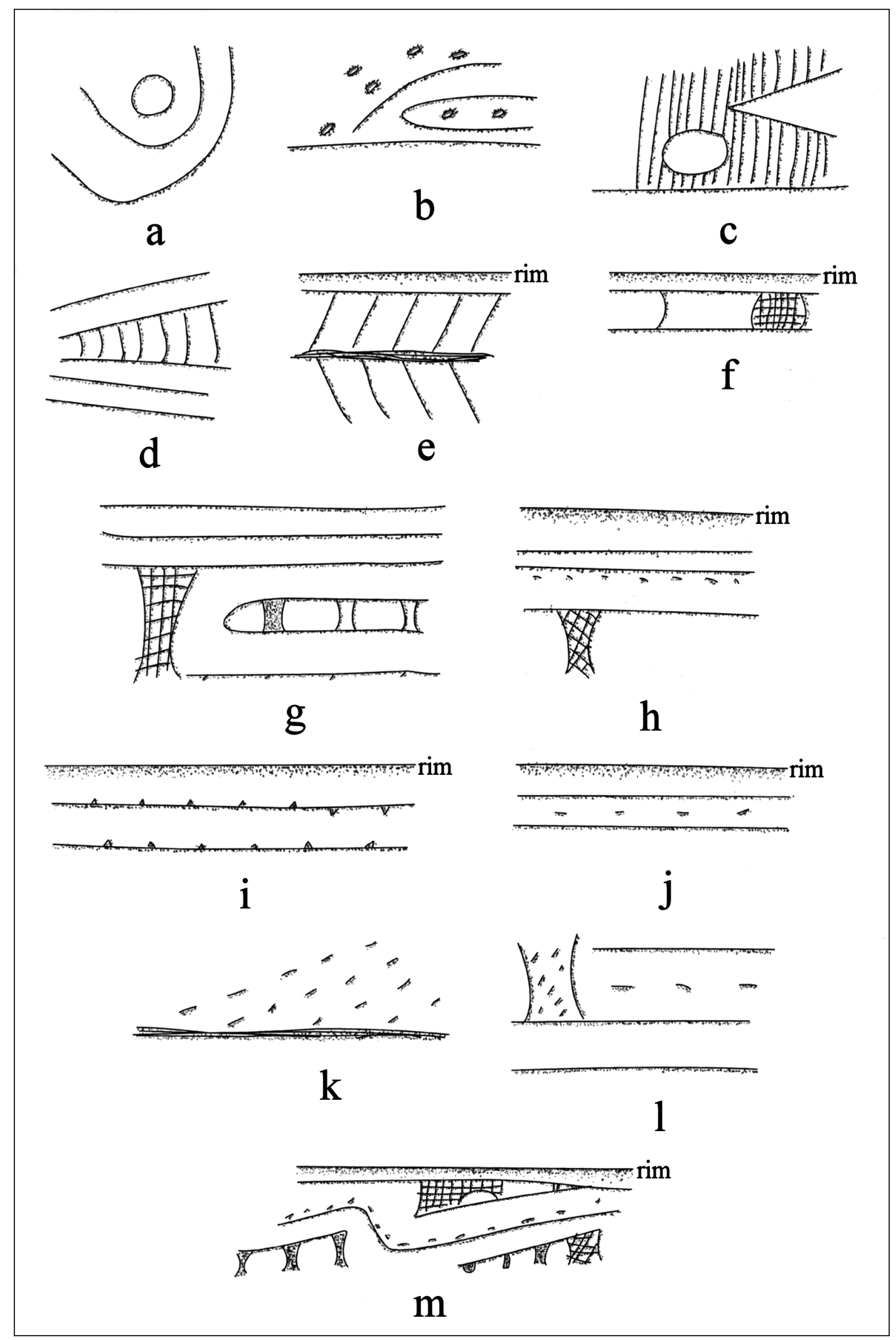

Figure 11. Decorative elements on selected fine ware and utility ware sherds from the Burial Plot excavations at the Hatchel site: a, incised-appliqued; $b$, $k$, incisedpunctated; c-d, f-g, i, m, engraved; e, incised; h, j, l, engraved-punctated. 


\section{Pipe Sherds}

There are two ceramic pipe sherds in the Village Plot 1 collection. Both are from Red River long stemmed pipes, probably var. Haley (see Hoffman 1967), one a bone-tempered pipe stem (F.S. 109-1), and the other a bowl sherd (F.S. 136-1)

\section{Summary and Conclusions}

The Caddo ceramic sherds from Village Plot 1 (as well as Village Plot 2 and Burial Plots 1-4, see Figure 3) at the Hatchel site are from Late Caddo period, Texarkana phase vessels. This includes sherds from vessels of the types Barkman Engraved, Hatchel Engraved, Simms Engraved, Hodges Engraved, Foster Trailed-Incised, Keno Trailed, McKinney Plain, Karnack Brushed-Incised, and Nash Neck Banded (see Suhm and Jelks 1962). Most, if not all, of these types can be considered components of the locally-made Late Caddo period ceramic assemblage at the Hatchel site, although there are a few sherds (shell-tempered in the main) that are not considered to have been locally-made, but are instead trade wares made by Caddo potters in other parts of the Red River basin.

The Hatchel site village ceramics are almost exclusively tempered with grog (or crushed pottery sherds), but a few have crushed and burned bone, crushed hematite, and a few sherds ( $\mathrm{n}=10$, or $2.4 \%$ of the sherds analyzed in detail) are shell-tempered. These shell-tempered vessels were either made sometime after ca. A.D. 1300 by McCurtain phase Caddo potters living upstream along the Red River from the Hatchel site, or after ca. A.D. 1600 by Belcher phase potters living downstream in the Great Bend area of the Red River (see Perttula et al. 2012).

The sherds from the Village Plot 1 area are from vessels that were primarily fired in a low oxygen or reducing environment, particularly the fine wares, but both the utility wares and plain wares were commonly fired in a high oxygen or oxidizing environment. Some of the vessels were deliberately smudged/ sooted during firing. The vessel sherds were regularly smoothed on one or both surfaces after they had been manufactured - utility wares were smoothed almost exclusively on the interior vessel surface-and a significant number of the fine wares were burnished on one or both surfaces. The sherds from all three wares are from vessels with thick, flat, and durable bases, and moderately thick (means of 6.91-7.42 mm by ware) rim and body walls.

About $53 \%$ of the Village Plot 1 decorated sherds are from fine ware vessels, including engraved, engraved-punctated, trailed, and red-slipped vessel sherds; similar proportions were noted in the Village Areas I-V at the Hatchel site (Perttula and Nelson 2003). The few engraved-punctated sherds $(n=7)$ are from Barkman Engraved carinated bowls; there is an engraved-appliqued sherd from another village area that may be from a Belcher Engraved vessel (e.g., Webb 1959:122). Other fine wares are 64 sherds from Keno Trailed bottles and bowls, as well as Hodges Engraved and Simms Engraved vessel sherds. The common occurrence of Keno Trailed sherds in Village Plot 1 indicates that the principal occupation took place in the latter part of the Texarkana phase, after ca. A.D. 1550/1600

In terms of the number of sherds, the coarse-tempered utility wares in Village Plot 1 are dominated by appliqued sherds $(n=41)$ from McKinney Plain and Cass Appliqued vessels, along with Karnack BrushedIncised ( $n=31)$, and Foster Trailed-Incised jar sherds $(n=53)$. There are only a few Nash Neck Banded sherds $(n=6)$ from this village area, and none from the Village Plot 1 and 2 burials. However, Nash Neck Banded jars are not uncommon in Burial Plots 1-4, and in the primary mound platform deposits (Laughlin 1940). Finally, about $13 \%$ of the utility wares have rows of punctations (primarily tool/instrument punctated, but also fingernail punctated) on the rim of cooking jars, usually extending from just below the lip to 
the rim-body juncture. Sometimes these punctated vessels have appliqued ridges and appliqued zones on the rim and the body, respectively, as well as strap handles (Suhm and Jelks 1962:Plate 791-m).

There is one sherd from Village Plot 1 that may testify to interaction and contact between the Nasoni Caddo and Lower Mississippi Valley groups. This is a rim from a Sanson Incised (see Phillips 1970:159) vessel. Kelley (1997:54) has noted that Sanson Incised "is most abundant on Plaquemine sites in the Catahoula Lake region of east central Louisiana," but it is also apparently present in some quantity on sites on the lower Red River in northwestern Louisiana (Girard 2004:56-57). Although not recovered during the WPA excavations at Hatchel, there is also a lower Arkansas River Carson Red on buff var. Olmond vessel (Phillips 1970:63) from a burial looted in the late 1970s in the village area, as well as a red on buff painted sherd from structure zone $\mathrm{H}$ in the platform mound (see Part I, this volume).

The proportion of fine wares to utility wares (53\% to 47\%) in the Village Plot 1 ceramic assemblage at the Hatchel site is notable given the likely age of the assemblage (post-dating ca. A.D. 1550), and the supposition that the Nasoni Caddo were successful maize and bean farmers, as were virtually all Red River Caddo peoples by this time (cf. Perttula et al. 2014). Other Late Caddo period ceramic assemblages on the Red River both upstream and downstream from the Hatchel site are much different, with the proportion of fine wares ranging from only 9-26\% (Kelley 1997:Table 7; McKinnon 2013; Perttula 2008b:Table 7; Webb 1959:Table 1). Only at the nearby Roseborough Lake site is there a comparable proportion of fine wares $(50 \%)$ in village areas there (Gilmore 1986), and fine wares are also much more abundant than utility wares at the Cedar Grove site (Schambach and Miller 1984:109). It may be that the assemblage in Village Plot 1, as well as at the Roseborough Lake and Cedar Grove sites, is distinct in its high proportion of fine wares because of the status of the families living there - and perhaps their focus of food serving and feasting and/or that plain wares may also have been used in the cooking and storage of maize and other food stuffs, skewing the correlation between cooking and utility ware jars in this Caddo community.

\section{Acknowledgments}

I thank Shawn Marceaux for his assistance in the analysis of the ceramic sherds from Village Plot 1 at the Hatchel site. I also want to thank Dr. Darrell Creel, Carolyn Spock, and Laura Nightengale for facilitating this study; the 1938-1939 WAP photographs are reproduced courtesy of the Texas Archeological Research Laboratory at The University of Texas at Austin. Lance Trask and Sandra Hannum prepared the figures for this article.

\section{References Cited}

Brown, J. A.

1996 The Spiro Ceremonial Center: The Archaeology of Arkansas Valley Caddoan Culture in Eastern Oklahoma. 2 Vols. Memoirs No. 29. Museum of Anthropology, University of Michigan, Ann Arbor.

Dunnell, R.C.

1978 Style and Function: A Fundamental Dichotomy. American Antiquity 43(2):192-202.

Gilmore, K.

1986 French-Indian Interaction at an Early Eighteenth Century Post: The Roseborough Lake Site, Bowie County, Texas. Contributions in Archaeology 3. Institute of Applied Sciences, North Texas State University, Denton. 
Girard, J. S.

2004 Regional Archaeology Program, Management Unit 1, Fifteenth Annual Report. Northwestern State University of Louisiana, Natchitoches.

Hoffman, M. E.

1967 Ceramic Pipe Style Chronology Along the Red River Drainage in Southwestern Arkansas. The Arkansas Archaeologist 8(1):4-14.

Kelley, D. B.

2012 The Belcher Phase: Sixteenth- and Seventeenth-Century Caddo Occupation of the Red River Valley in Northwest Louisiana and Southwest Arkansas. In The Archaeology of the Caddo, edited by T. K. Perttula and C. P. Walker, pp. 411-430. University of Nebraska Press, Lincoln.

Kelley, D. B. (editor)

1997 Two Caddoan Farmsteads in the Red River Valley: The Archeology of the McLelland and Joe Clark Sites. Research Series No. 51. Arkansas Archeological Survey, Fayetteville.

Laughlin, J. T.

1940 Laboratory Study of the Pottery, Potsherds and Artifacts from Site ET-30 Mound. MS on file, Texas Archeological Research Laboratory, The University of Texas at Austin.

McKinnon, D. P.

2013 Battle Mound: Exploring Space, Place, and History of a Red River Caddo Community in Southwest Arkansas. Ph.D. dissertation, Department of Anthropology, University of Arkansas, Fayetteville.

Perttula, T. K.

2005 1938-1939 WPA Excavations at the Hatchel Site (41BW3) on the Red River in Bowie County, Texas. Southeastern Archaeology 24(2):180-198.

2008a Caddo Agriculture on the Western Frontier of the Eastern Woodlands. Plains Anthropologist 53(205):79-105.

2008b The Archeology of the Roitsch Site (41RR16), an Early to Historic Caddo Period Village on the Red River in Northeast Texas. In Collected Papers from Past Texas Archeological Society Summer Field Schools, edited by T. K. Perttula, pp. 313-628. Special Publication No. 5. Texas Archeological Society, San Antonio.

2010 Woodland and Caddo Ceramic Traditions in East Texas. In Regional Summaries of Prehistoric and Early Historic Ceramics in Texas for the Council of Texas Archaeologists, assembled and edited by L. W. Ellis and T. K. Perttula, pp. 13-41. CTA Ceramics Protocol Committee, Austin accessed on April 26, 2012, at http://www.counciloftexasarchaeologists.org/index.php? option=com_content\&ta sk $=$ view\&id $=87 \&$ ltemid $=94$

2013 Caddo Ceramics in East Texas. Bulletin of the Texas Archeological Society 84:181-212.

Perttula, T. K. (editor)

2005 Archeological Investigations at the Pilgrim's Pride Site (41CP304), a Titus Phase Community in the Big Cypress Creek Basin, Camp County, Texas. 2 Vols. Report of Investigations No. 30. Archeological \& Environmental Consultants, LLC, Austin. 
Perttula, T. K. and L. W. Ellis

2012 The Hickory Hill Site (41CP408): Archeological Investigations at a Middle Caddo Site in the Little Cypress Creek Basin in East Texas. Document No. 120055. Atkins, Austin.

Perttula, T. K. and B. Nelson

2003 Archeological Investigations of Village Areas at the Hatchel Site (41BW3), Bowie County, Texas. Report of Investigations No. 58. Archeological \& Environmental Consultants, LLC, Austin.

Perttula, T. K., R. Z. Selden, Jr., and D. Wilson

2014 Corn is Life: Temporal Trends in the Use of Corn (Zea mays) by Caddo Peoples from Radiocarbondated Samples and Stable Isotope Analyses. Bulletin of the Texas Archeological Society 85, in press.

Perttula, T. K., M. B. Trubitt, and J. S. Girard

2012 The Use of Shell-Tempered Pottery in the Caddo Area of the Southeastern United States. Southeastern Archaeology 30(2):242-267.

Phillips, P.

1970 Archaeological Survey in the Lower Yazoo Basin, Mississippi, 1949-1955. Papers of the Peabody Museum of Archaeology and Ethnology, Vol. 60. Peabody Museum of Archaeology and Ethnology, Harvard University, Cambridge.

Rice, P. M.

1987 Pottery Analysis: A Sourcebook. University of Chicago Press, Chicago.

Selden, R. Z., Jr. and T. K. Perttula

2013a Radiocarbon Trends and the East Texas Caddo Tradition (ca. A.D. 800-1680). Southeastern Archaeology 32(1):85-96.

2013b Temporal Dynamics of East Texas Caddo Sites with 10 or More Radiocarbon Dates. Journal of Northeast Texas Archaeology 41:81-99.

Suhm, D. A. and E. B. Jelks (editors)

1962 Handbook of Texas Archeology: Type Descriptions. Special Publication No. 1, Texas Archeological Society, and Bulletin No. 4, Texas Memorial Museum, Austin. Reprinted in 2009, Gustav's Library, Davenport, Iowa.

Teltser, P. A.

1993 An Analytic Strategy for Studying Assemblage-Scale Ceramic Variation: A Case Study from Southeast Missouri. American Antiquity 58(3):530-543.

VanPool, T. L. and R. D. Leonard

2011 Quantitative Analysis in Archaeology. Wylie-Blackwell, Chichester, United Kingdom.

Wilson, D.

2012 Bioarchaeological Evidence of Subsistence Strategies among the East Texas Caddo. In The Archaeology of the Caddo, edited by T. K. Perttula and C. P. Walker, pp. 86-116. University of Nebraska Press, Lincoln.

Wilson, D. and T. K. Perttula

2013 Reconstructing the Paleodiet of the Caddo through Stable Isotopes. American Antiquity 78(4):702-723. 
Appendix 1, Detailed analysis of sherds from the Village Plot 1 area at the Hatchel site.

\begin{tabular}{|c|c|c|c|c|c|c|c|}
\hline $\begin{array}{l}\text { Provenience } \\
\text { ( } \mathrm{cm} \text { bs or } \mathrm{cm} \mathrm{bd} \text { ) }\end{array}$ & Prov. No. & $\begin{array}{l}\text { Sherd } \\
\text { type }\end{array}$ & Temper & $\mathrm{FC}$ & ST & $\begin{array}{l}\text { Th } \\
(\mathrm{mm})\end{array}$ & Comments \\
\hline \multicolumn{8}{|l|}{ Plain Sherds } \\
\hline $30 \mathrm{~L} 12$ & 39 & body & grog & A & - & 7.4 & \\
\hline 30R3 & 23 & body & grog-org. & $\mathrm{H}$ & - & 8.6 & \\
\hline 30R9 & 18 & base & grog-org. & $\mathrm{B}$ & I SM & 10.7 & \\
\hline 30R10 & 5 & body & grog & $\mathrm{B}$ & I/E SM & 5.4 & \\
\hline $35 \mathrm{R} 1$ & 36 & body & grog & $\mathrm{E}$ & I/E SM & 7.7 & \\
\hline $35 \mathrm{R} 10$ & 9 & body & grog & $* *$ & - & 7.0 & \\
\hline $40 \mathrm{R} 2$ & 13 & body & grog-bone & $\mathrm{B}$ & E B & 6.3 & $\mathrm{Bt}$ \\
\hline $45 \mathrm{R} 6$ & 3 & base & grog-bone & $\mathrm{E}$ & - & 13.2 & \\
\hline $45 \mathrm{R} 6$ & 3 & body & grog & B & E B & 6.8 & $\mathrm{Bt}$ \\
\hline $45 \mathrm{R} 8$ & 46 & body & grog-bone/SP & $\mathrm{F}$ & I/E SM & 6.5 & \\
\hline $45 \mathrm{R} 8$ & 46 & body & grog-org. & $\mathrm{F}$ & E B & 6.3 & \\
\hline $50 \mathrm{~L} 2$ & 141 & rim & grog & $\mathrm{H}$ & - & 5.5 & \\
\hline $60 \mathrm{~L} 9$ & 118 & base & grog-org. & $\mathrm{C}$ & - & 11.7 & \\
\hline 60R2 & 29 & body & grog & $* *$ & - & 6.4 & \\
\hline $65 \mathrm{~L} 4$ & 191 & body & grog-shell & $\mathrm{C}$ & - & 8.0 & \\
\hline $65 \mathrm{R} 1$ & 38 & body & grog-bone & $* *$ & - & 8.0 & \\
\hline $65 \mathrm{R} 4$ & 21 & body & grog-bone-ht. & A & - & 8.7 & \\
\hline $65 \mathrm{R} 4$ & 31 & body & grog & $\mathrm{B}$ & E SM & 6.5 & \\
\hline $65 \mathrm{R} 5$ & 42 & body & grog & $\mathrm{F}$ & I/E SM & 6.9 & \\
\hline $70 \mathrm{~L}_{-}$ & 162 & body & grog-bone & $* *$ & - & 7.9 & \\
\hline $70 \mathrm{~L} 9$ & 120 & body & grog-bone-ht. & $\mathrm{A}$ & - & 7.2 & \\
\hline $70 \mathrm{R} 3$ & 97 & body & grog & $\mathrm{F}$ & - & 6.5 & \\
\hline $75 \mathrm{R} 4$ & 20 & body & grog/SP & A & E SM & 7.2 & \\
\hline 80L10 & 126 & rim & grog & A & I/E SM & 6.9 & EV-RO \\
\hline 80L10 & 126 & body & grog & $\mathrm{H}$ & - & 7.7 & \\
\hline 80L11 & 127 & base & grog-bone & B & - & 13.2 & \\
\hline Village Surface & - & rim & grog & G & - & 9.3 & $\begin{array}{l}\text { int. organic } \\
\text { residue; D-FL }\end{array}$ \\
\hline Village Surface & - & rim & grog & $\mathrm{G}$ & I SM & 8.4 & INV-RO \\
\hline Village Surface & - & body & grog & $* *$ & I SM & 7.4 & \\
\hline Village Surface & - & body & grog & $* *$ & - & 8.3 & \\
\hline Village Surface & - & body & grog & $* *$ & I SM & 7.6 & \\
\hline Village Surface & - & body & grog-ht. & $* *$ & I/E SM & 7.6 & \\
\hline Village Surface & - & body & grog & $* *$ & - & 7.7 & \\
\hline Village Surface & - & body & grog & $\mathrm{A}$ & - & 7.9 & \\
\hline
\end{tabular}


Appendix 1, Detailed analysis of sherds from the Village Plot 1 area at the Hatchel site, cont.

\begin{tabular}{|c|c|c|c|c|c|c|c|}
\hline $\begin{array}{l}\text { Provenience } \\
\text { (cm bs or } \mathrm{cm} \mathrm{bd} \text { ) }\end{array}$ & Prov. No. & $\begin{array}{l}\text { Sherd } \\
\text { type }\end{array}$ & Temper & $\mathrm{FC}$ & ST & $\begin{array}{c}\text { Th } \\
(\mathrm{mm})\end{array}$ & Comments \\
\hline Village Surface & - & body & grog & $\mathrm{A}$ & - & 6.7 & \\
\hline Village Surface & - & body & grog & $\mathrm{B}$ & I SM & 6.7 & \\
\hline Village Surface & - & body & none & $\mathrm{G}$ & E SM & 7.5 & \\
\hline Village Surface & - & body & grog & $\mathrm{B}$ & I SM & 6.7 & \\
\hline Village Surface & - & body & grog/SP & $\mathrm{A}$ & - & 8.4 & \\
\hline Village Surface & - & body & grog & $\mathrm{B}$ & $\mathrm{I} / \mathrm{E} \mathrm{SM}$ & 7.5 & \\
\hline Village Surface & - & body & grog & $\mathrm{A}$ & E SM & 7.9 & \\
\hline Village Surface & - & body & grog/SP & $\mathrm{F}$ & I SM & 8.5 & \\
\hline Village Surface & - & body & grog & $\mathrm{F}$ & $\mathrm{I} / \mathrm{E} \mathrm{SM}$ & 5.9 & \\
\hline Village Surface & - & body & grog-bone & $\mathrm{E}$ & - & 6.9 & \\
\hline Village Surface & - & body & grog-org. & $\mathrm{G}$ & - & 6.5 & \\
\hline Village Surface & - & body & grog & $\mathrm{F}$ & I SM & 6.0 & \\
\hline Village Surface & - & body & grog & $\mathrm{F}$ & - & 6.9 & \\
\hline Village Surface & - & body & grog-org. & $\mathrm{G}$ & - & 7.0 & \\
\hline Village Surface & - & body & shell & $\mathrm{G}$ & - & 6.5 & \\
\hline Village Surface & - & body & grog-org. & $\mathrm{G}$ & - & 8.5 & \\
\hline Village Surface & - & body & grog & $\mathrm{A}$ & - & 8.4 & \\
\hline Village Surface & - & body & grog & $\mathrm{G}$ & E SM & 8.7 & \\
\hline Village Surface & - & body & grog & $\mathrm{G}$ & $\mathrm{I} / \mathrm{E} \mathrm{SM}$ & 8.2 & \\
\hline Village Surface & - & body & grog & $\mathrm{G}$ & I SM & 7.6 & \\
\hline Village Surface & - & body & grog & $\mathrm{D}$ & - & 8.7 & \\
\hline Village Surface & - & body & grog & $\mathrm{F}$ & E SM & 5.7 & \\
\hline Village Surface & - & body & grog-ht. & $\mathrm{E}$ & - & 7.0 & \\
\hline Village Surface & - & body & grog-ht. & $\mathrm{E}$ & - & 6.6 & \\
\hline Village Surface & - & body & grog & $\mathrm{A}$ & - & 6.0 & \\
\hline Village Surface & - & body & grog & $\mathrm{F}$ & - & 8.3 & \\
\hline Village Surface & - & body & grog & $\mathrm{F}$ & I SM & 7.5 & \\
\hline Village Surface & - & body & grog & $\mathrm{H}$ & - & 8.3 & \\
\hline Village Surface & - & body & grog-org./SP & $\mathrm{G}$ & - & 6.3 & \\
\hline Village Surface & - & body & grog & $\mathrm{B}$ & - & 5.4 & \\
\hline Village Surface & - & body & grog & $\mathrm{G}$ & E SM & 8.0 & \\
\hline Village Surface & - & body & grog & $\mathrm{F}$ & - & 5.4 & \\
\hline Village Surface & - & body & grog & $\mathrm{G}$ & - & 7.4 & \\
\hline Village Surface & - & body & grog-org. & $\mathrm{G}$ & E SM & 6.5 & $\mathrm{Bt}$ \\
\hline Village Surface & - & body & grog-bone-ht. & $\mathrm{G}$ & E B & 6.3 & $\mathrm{Bt}$ \\
\hline Village Surface & - & body & grog/SP & $\mathrm{E}$ & E SM & 6.5 & $\mathrm{Bt}$ \\
\hline Village Surface & - & base & grog & A & - & 13.2 & \\
\hline Village Surface & - & base & grog & $\mathrm{F}$ & - & 10.3 & \\
\hline Village Surface & - & base & grog-bone & $\mathrm{E}$ & E SM & 11.3 & \\
\hline Village Surface & - & base & grog-bone & A & I SM & 10.2 & \\
\hline Village Surface & - & base & grog-org. & $\mathrm{F}$ & - & 9.9 & \\
\hline Village Surface & - & base & grog & $\mathrm{B}$ & - & 11.0 & \\
\hline
\end{tabular}


Appendix 1, Detailed analysis of sherds from the Village Plot 1 area at the Hatchel site, cont.

\begin{tabular}{|c|c|c|c|c|c|c|c|}
\hline $\begin{array}{l}\text { Provenience } \\
\text { ( } \mathrm{cm} \mathrm{bs} \mathrm{or} \mathrm{cm} \mathrm{bd} \text { ) }\end{array}$ & Prov. No. & $\begin{array}{l}\text { Sherd } \\
\text { type }\end{array}$ & Temper & $\mathrm{FC}$ & ST & $\begin{array}{l}\text { Th } \\
(\mathrm{mm})\end{array}$ & Comments \\
\hline Village Surface & - & base & grog & $\mathrm{G}$ & I SM & 14.0 & \\
\hline- & - & rim & grog & $\mathrm{B}$ & - & 5.3 & \\
\hline- & - & rim & grog & $\mathrm{F}$ & I SM & 8.3 & \\
\hline- & - & rim & grog & $\mathrm{C}$ & - & 6.9 & $\mathrm{Bt}$ \\
\hline- & - & body & grog & $\mathrm{A}$ & - & 7.2 & \\
\hline- & - & body & grog-org. & $\mathrm{G}$ & E SM & 8.4 & \\
\hline- & - & body & grog-org. & $\mathrm{C}$ & - & 6.5 & \\
\hline- & - & body & grog & $\mathrm{G}$ & I SM & 8.8 & \\
\hline- & - & body & grog-org. & G & I/E SM & 8.0 & \\
\hline- & - & body & grog & $\mathrm{F}$ & E SM & 8.0 & \\
\hline- & - & body & grog/SP & $\mathrm{F}$ & E SM & 6.3 & \\
\hline- & - & body & grog/SP & $\mathrm{F}$ & E SM & 8.2 & \\
\hline- & - & body & grog & $\mathrm{B}$ & I SM & 5.5 & \\
\hline- & - & body & grog-bone & A & - & 7.4 & \\
\hline- & - & body & grog & $\mathrm{E}$ & - & 5.2 & \\
\hline- & - & body & grog & G & - & 4.9 & \\
\hline- & - & body & grog & $\mathrm{G}$ & - & 7.2 & \\
\hline- & - & body & grog & $\mathrm{F}$ & - & 7.5 & \\
\hline- & - & body & grog & $\mathrm{G}$ & E SM & 6.9 & \\
\hline- & - & body & grog & B & I/E SM & 4.8 & \\
\hline- & - & body & grog & $\mathrm{E}$ & I SM & 6.8 & \\
\hline- & - & body & grog & $\mathrm{B}$ & - & 6.0 & \\
\hline- & - & body & grog & A & - & 10.1 & \\
\hline- & - & body & grog & $\mathrm{F}$ & I/E SM & 6.2 & \\
\hline- & - & body & grog & $\mathrm{G}$ & - & 8.6 & \\
\hline- & - & body & grog & A & - & 8.8 & \\
\hline- & - & body & grog & $\mathrm{F}$ & - & 8.1 & \\
\hline- & - & body & grog & $\mathrm{C}$ & - & 7.0 & \\
\hline- & - & body & grog & $\mathrm{G}$ & - & 5.8 & \\
\hline- & - & body & grog & $\mathrm{G}$ & - & 7.5 & \\
\hline- & - & body & grog/ht. & B & - & 6.3 & \\
\hline- & - & body & grog & $\mathrm{F}$ & - & 7.8 & \\
\hline- & - & body & grog-bone & $\mathrm{A}$ & - & 8.2 & \\
\hline- & - & body & grog-shell & A & - & 7.4 & \\
\hline- & - & body & grog & $\mathrm{F}$ & I SM & 8.1 & \\
\hline- & - & body & grog & A & I/E SM & 8.5 & \\
\hline- & - & body & grog & B & I/E SM & 7.6 & \\
\hline- & - & body & grog & A & I/E SM & 8.7 & \\
\hline- & - & body & grog-org. & $\mathrm{A}$ & - & 8.6 & \\
\hline- & - & body & grog-bone & $\mathrm{H}$ & - & 8.7 & \\
\hline- & - & body & grog & $\mathrm{B}$ & I/E SM & 5.4 & \\
\hline- & - & body & grog & $\mathrm{B}$ & I/E SM & 8.7 & \\
\hline
\end{tabular}


Appendix 1, Detailed analysis of sherds from the Village Plot 1 area at the Hatchel site, cont.

\begin{tabular}{|c|c|c|c|c|c|c|c|}
\hline $\begin{array}{l}\text { Provenience } \\
(\mathrm{cm} \text { bs or } \mathrm{cm} \mathrm{bd})\end{array}$ & Prov. No. & $\begin{array}{l}\text { Sherd } \\
\text { type }\end{array}$ & Temper & $\mathrm{FC}$ & ST & $\begin{array}{c}\mathrm{Th} \\
(\mathrm{mm})\end{array}$ & Comments \\
\hline- & - & body & grog & $\mathrm{E}$ & I/E SM & 8.7 & \\
\hline- & - & body & grog & B & I/E SM & 7.6 & \\
\hline- & - & body & grog-bone & A & - & 6.1 & \\
\hline- & - & body & bone & A & - & 8.2 & \\
\hline- & - & body & grog & $\mathrm{B}$ & - & 4.9 & \\
\hline- & - & body & grog & $\mathrm{G}$ & E SM & 7.2 & \\
\hline- & - & body & grog & $\mathrm{E}$ & - & 6.8 & \\
\hline- & - & body & grog-bone & $\mathrm{C}$ & E SM & 4.7 & \\
\hline- & - & body & shell & $\mathrm{H}$ & I/E SM & 6.1 & \\
\hline- & - & body & grog & $\mathrm{B}$ & - & 8.0 & \\
\hline- & - & body & grog & B & - & 5.8 & \\
\hline- & - & body & grog & $\mathrm{E}$ & - & 5.8 & \\
\hline- & - & body & grog & $\mathrm{F}$ & - & 5.1 & \\
\hline- & - & body & grog & A & - & 7.6 & \\
\hline- & - & body & grog & $\mathrm{E}$ & - & 8.0 & \\
\hline- & - & body & grog & $\mathrm{G}$ & - & 7.4 & \\
\hline- & - & body & grog & $\mathrm{C}$ & - & 8.0 & \\
\hline- & - & body & grog/SP & B & I/E SM & 5.0 & \\
\hline- & - & body & grog & B & I/E SM & 6.0 & \\
\hline- & - & body & grog & G & - & 4.5 & \\
\hline- & - & body & grog-ht. & G & - & 5.1 & \\
\hline- & - & body & bone & $\mathrm{H}$ & - & 6.0 & \\
\hline- & - & body & grog & A & E SM & 4.1 & \\
\hline- & - & body & grog & $\mathrm{B}$ & $\mathrm{I} / \mathrm{E} \mathrm{SM}$ & 5.5 & \\
\hline- & - & body & grog-bone & $\mathrm{H}$ & - & 6.2 & \\
\hline- & - & body & grog & G & I SM & 4.9 & \\
\hline- & - & body & shell & $\mathrm{A}$ & - & 8.1 & \\
\hline- & - & body & grog & $\mathrm{H}$ & E SM & 5.8 & \\
\hline- & - & body & grog & $\mathrm{C}$ & - & 8.1 & \\
\hline- & - & body & grog & $* *$ & - & 8.1 & \\
\hline- & - & body & grog & $\mathrm{E}$ & E SM & 7.2 & \\
\hline- & - & body & grog & A & - & 5.5 & \\
\hline- & - & body & grog & $\mathrm{A}$ & - & 5.5 & \\
\hline- & - & body & grog & $\mathrm{A}$ & - & 7.4 & \\
\hline- & - & body & grog & $\mathrm{E}$ & E SM & 6.4 & \\
\hline- & - & body & grog & $\mathrm{B}$ & ESM & 7.5 & \\
\hline- & - & body & grog-org. & $\mathrm{C}$ & I/E SM & 6.6 & \\
\hline- & - & body & grog & $\mathrm{E}$ & E SM & 9.2 & \\
\hline- & - & body & grog-org. & $\mathrm{B}$ & E SM & 6.0 & \\
\hline- & - & body & grog & $\mathrm{B}$ & - & 7.1 & \\
\hline- & - & body & grog & $\mathrm{E}$ & I/E SM & 6.4 & \\
\hline- & - & body & grog & G & - & 7.6 & \\
\hline- & - & body & grog & $\mathrm{F}$ & I/E SM & 6.7 & \\
\hline
\end{tabular}


Appendix 1, Detailed analysis of sherds from the Village Plot 1 area at the Hatchel site, cont.

\begin{tabular}{|c|c|c|c|c|c|c|c|}
\hline $\begin{array}{l}\text { Provenience } \\
\text { ( } \mathrm{cm} \text { bs or } \mathrm{cm} \mathrm{bd} \text { ) }\end{array}$ & Prov. No. & $\begin{array}{l}\text { Sherd } \\
\text { type }\end{array}$ & Temper & $\mathrm{FC}$ & ST & $\begin{array}{c}\mathrm{Th} \\
(\mathrm{mm})\end{array}$ & Comments \\
\hline- & - & body & shell-grog & $\mathrm{G}$ & E SM & 7.4 & \\
\hline- & - & body & shell-grog & $\mathrm{F}$ & - & 9.2 & \\
\hline- & - & body & grog & $\mathrm{A}$ & - & 7.3 & \\
\hline- & - & body & grog & A & E SM & 6.4 & \\
\hline- & - & body & grog & $\mathrm{B}$ & I/E SM & 5.4 & \\
\hline- & - & body & grog-bone & $\mathrm{E}$ & I/E SM & 6.7 & \\
\hline- & - & body & grog/SP & A & - & 6.7 & \\
\hline- & - & body & grog & $\mathrm{F}$ & E SM & 7.8 & \\
\hline- & - & body & grog-bone & $\mathrm{F}$ & - & 8.0 & \\
\hline- & - & body & grog-org. & $\mathrm{G}$ & I SM & 8.3 & \\
\hline- & - & body & grog-bone & A & I SM & 6.5 & \\
\hline- & - & body & grog/SP & B & E SM & 7.0 & \\
\hline- & - & body & grog-bone & $\mathrm{F}$ & - & 6.8 & \\
\hline- & - & body & grog & $* *$ & E SM & 7.9 & \\
\hline- & - & body & grog-ht. & $\mathrm{F}$ & I/E SM & 7.7 & \\
\hline- & - & body & grog & A & - & 7.9 & \\
\hline- & - & body & grog & $\mathrm{B}$ & I/E SM & 6.5 & \\
\hline- & - & body & grog & B & E SM & 5.7 & \\
\hline- & - & body & grog & $\mathrm{B}$ & I SM & 7.9 & \\
\hline- & - & body & grog & $\mathrm{G}$ & E SM & 7.0 & \\
\hline- & - & body & grog/SP & $\mathrm{E}$ & I SM & 7.3 & \\
\hline- & - & body & grog & $\mathrm{E}$ & I SM & 9.4 & \\
\hline- & - & body & grog & $\mathrm{F}$ & - & 8.4 & \\
\hline- & - & body & grog & $* *$ & I SM & 8.5 & \\
\hline- & - & body & grog/SP & $\mathrm{G}$ & E SM & 7.6 & \\
\hline- & - & body & grog/SP & $\mathrm{E}$ & - & 7.7 & \\
\hline- & - & body & grog & $\mathrm{E}$ & - & 7.6 & \\
\hline- & - & body & grog-ht.-org. & $\mathrm{B}$ & $\mathrm{I} / \mathrm{E} / \mathrm{SM}$ & 5.7 & \\
\hline- & - & body & grog/SP & $\mathrm{E}$ & - & 10.1 & \\
\hline- & - & body & grog & $\mathrm{G}$ & I SM & 9.0 & \\
\hline- & - & body & grog & A & I/E SM & 7.7 & \\
\hline- & - & body & grog-bone & $\mathrm{A}$ & I/E SM & 6.3 & \\
\hline- & - & body & grog-bone-org. & $\mathrm{G}$ & I/E SM & 5.8 & \\
\hline- & - & body & shell & $\mathrm{G}$ & - & 5.0 & \\
\hline- & - & body & bone-grog-shell & $\mathrm{D}$ & - & 6.0 & \\
\hline- & - & body & grog & $\mathrm{G}$ & - & 6.2 & $\mathrm{Bt}$ \\
\hline- & - & body & grog-bone & $\mathrm{G}$ & - & 5.6 & $\mathrm{Bt}$ \\
\hline- & - & body & grog & $\mathrm{E}$ & E SM & 5.7 & $\mathrm{Bt}$ \\
\hline- & - & body & grog & $\mathrm{E}$ & E SM & 8.4 & $\mathrm{Bt}$ \\
\hline- & - & body & grog-org. & $\mathrm{B}$ & E SM & 8.2 & $\mathrm{Bt}$ \\
\hline- & - & body & grog & $\mathrm{B}$ & E B & 7.2 & $\mathrm{Bt}$ \\
\hline
\end{tabular}


Appendix 1, Detailed analysis of sherds from the Village Plot 1 area at the Hatchel site, cont.

\begin{tabular}{lcllllll}
\hline $\begin{array}{l}\text { Provenience } \\
(\mathrm{cm} \mathrm{bs} \mathrm{or} \mathrm{cm} \mathrm{bd)}\end{array}$ & Prov. No. & $\begin{array}{c}\text { Sherd } \\
\text { type }\end{array}$ & Temper & FC & ST & $\begin{array}{c}\text { Th } \\
(\mathrm{mm})\end{array}$ & Comments \\
\hline- & - & body & grog & G & E SM & 7.7 & Bt \\
- & - & body & grog & B & E SM & 7.7 & Bt \\
- & - & body & grog & G & E SM & 8.7 & Bt \\
& & & & & & & \\
- & - & base & grog-bone & B & - & 11.0 & \\
- & - & base & grog & G & - & 8.9 & \\
- & - & base & grog & B & - & 8.0 & \\
- & - & base & grog & $* *$ & - & 11.0 & \\
- & - & base & grog & G & - & 9.2 & \\
- & - & base & grog & A & - & 11.7 & \\
- & - & base & grog & E & - & 14.0 & \\
- & - & base & grog & F & - & 11.2 & \\
- & - & base & grog & E & I SM & 13.3 & \\
- & - & base & grog & $* *$ & - & 15.3 & \\
- & - & base & grog & G & I SM & 7.0 & \\
- & - & base & grog & B & I/E SM & 9.2 & \\
\hline
\end{tabular}

ht.=hematite; org.=organic; $\mathrm{SP}=$ sandy paste; $\mathrm{D}=$ direct rim; $\mathrm{EV}=$ everted rim; $\mathrm{INV}=$ =inverted rim; $\mathrm{RO}=$ rounded lip; $\mathrm{FL}=$ flat lip; $\mathrm{FC}=$ firing condition, $\mathrm{A}=$ oxidized; $\mathrm{B}=$ reduced; $\mathrm{C}-\mathrm{E}$, incompletely oxidized; $\mathrm{F}-\mathrm{H}$, fired in a reducing environment but cooled in the open air; **sooted, smudged, or refired; ST=surface treatment, I=interior; E=exterior; $\mathrm{SM}=$ smoothed; $\mathrm{B}=$ burnished; Th=thickness; $\mathrm{Bt}=$ bottle; $\mathrm{CB}=$ carinated bowl 


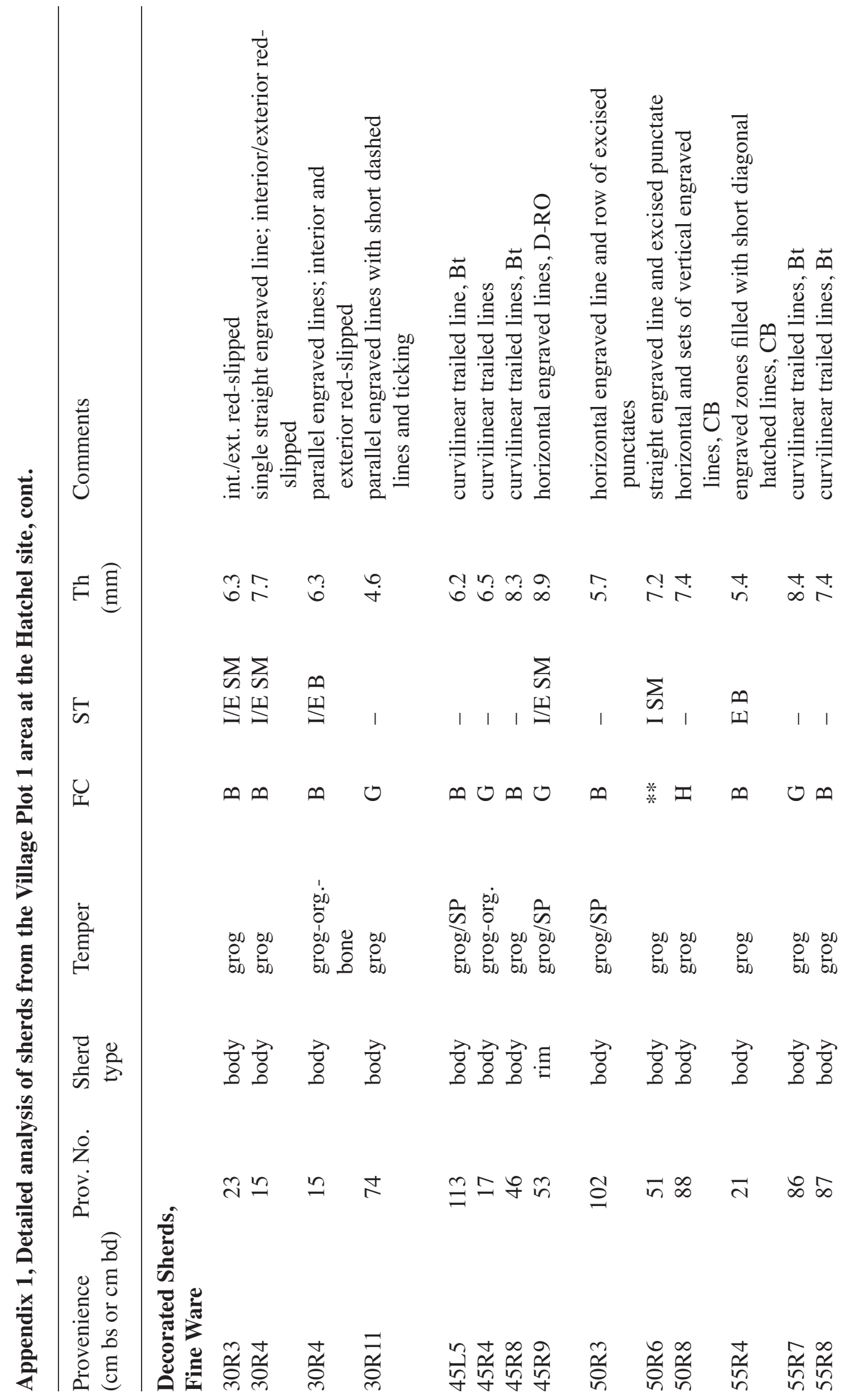




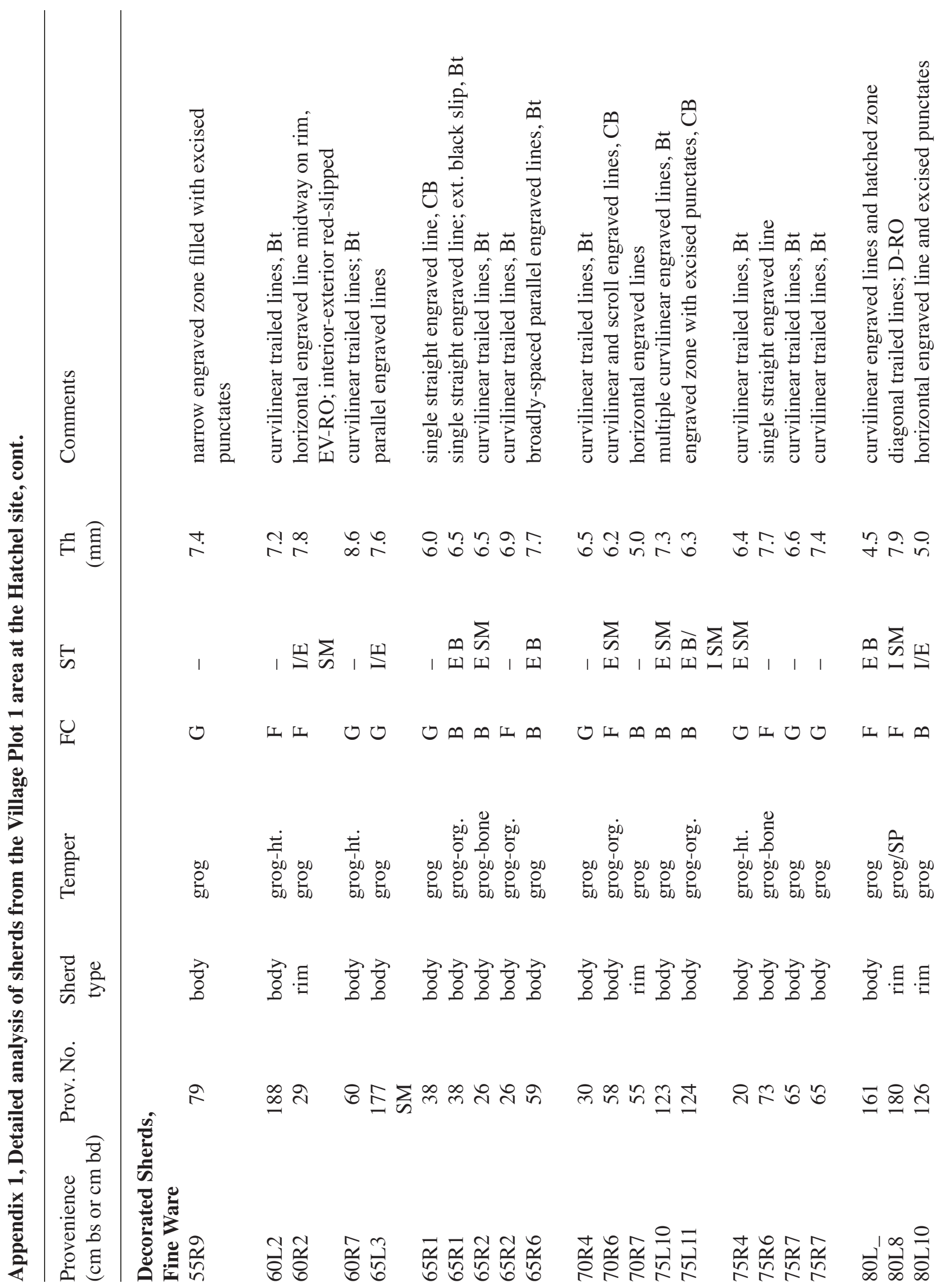




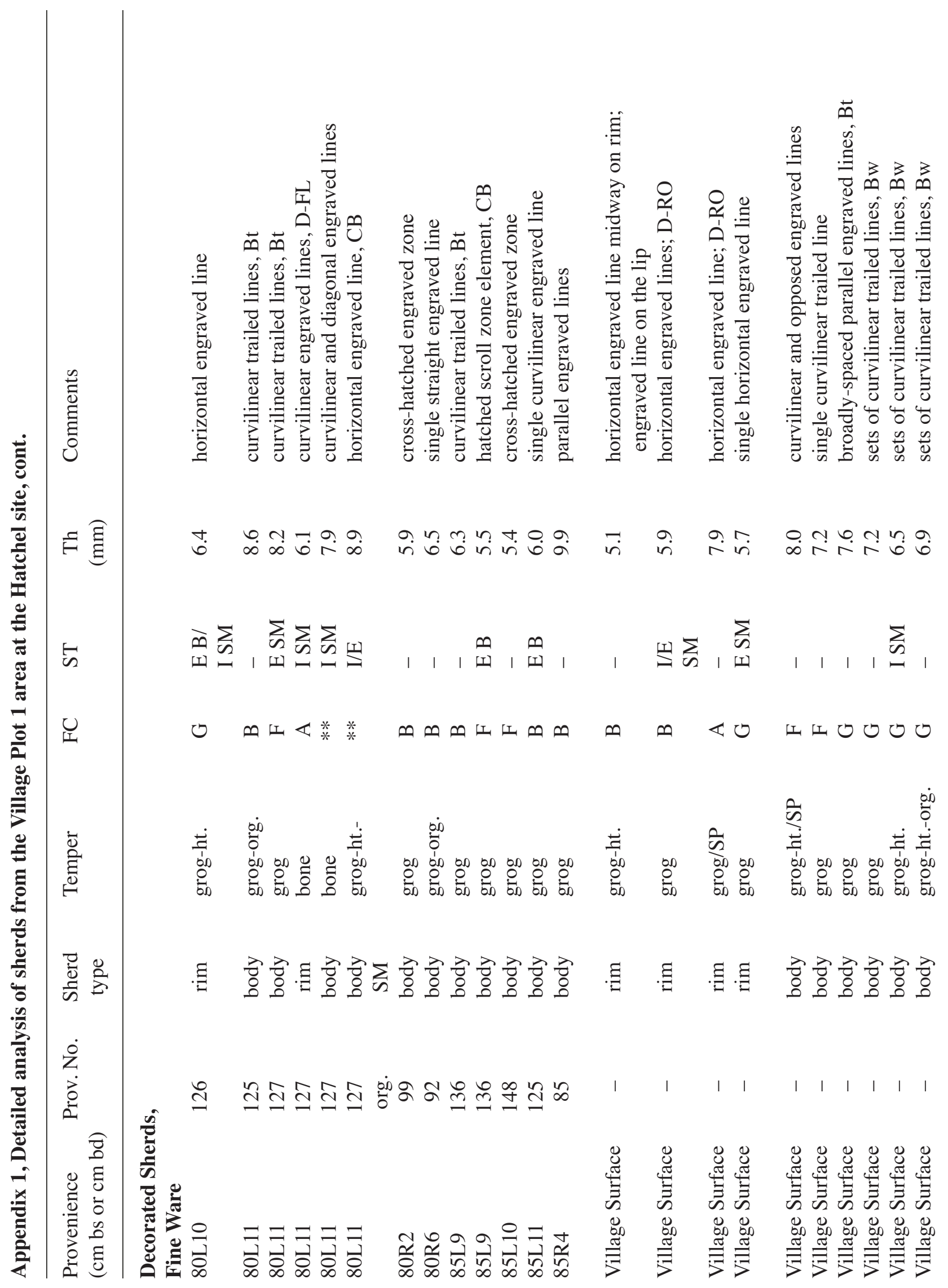




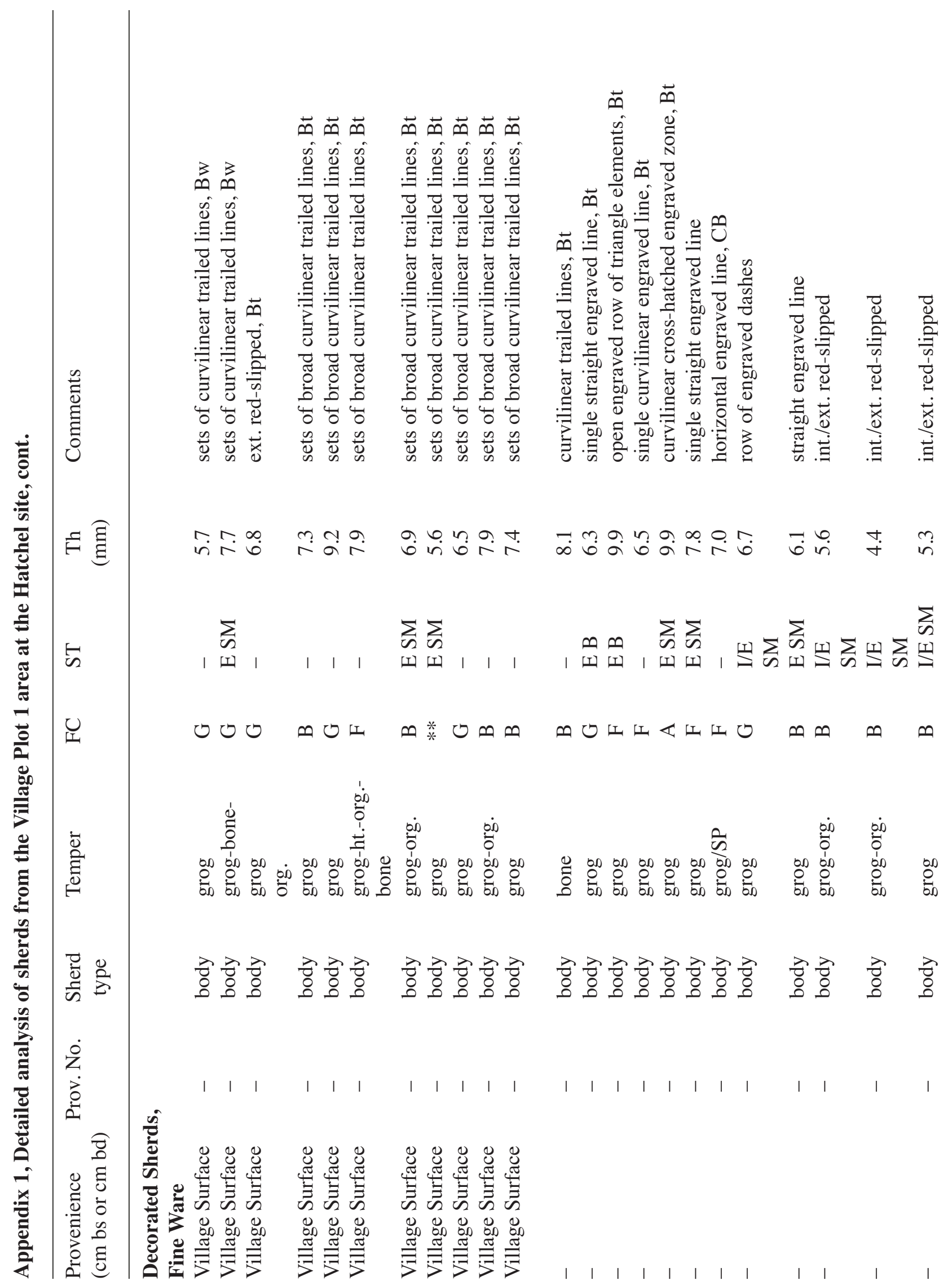




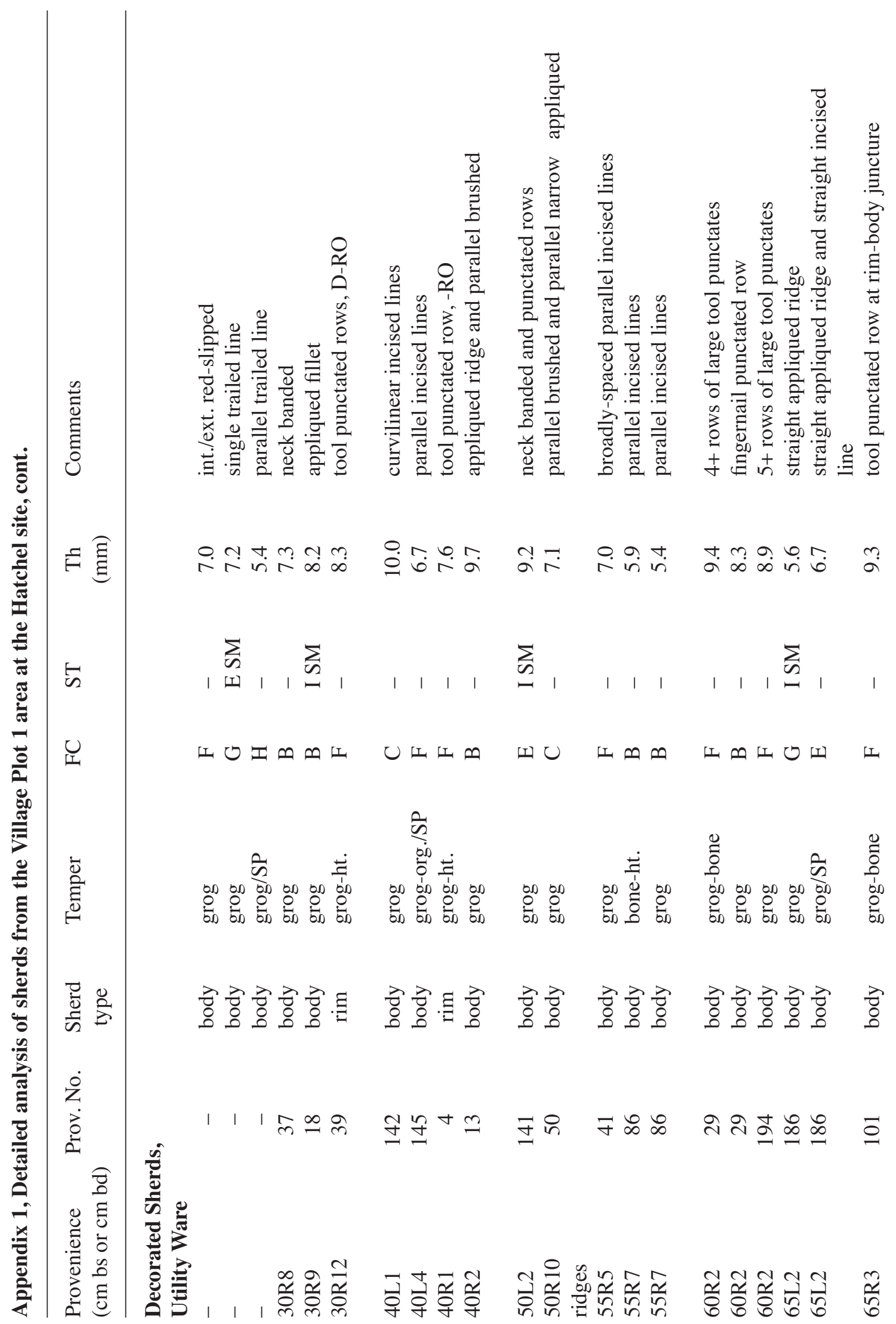




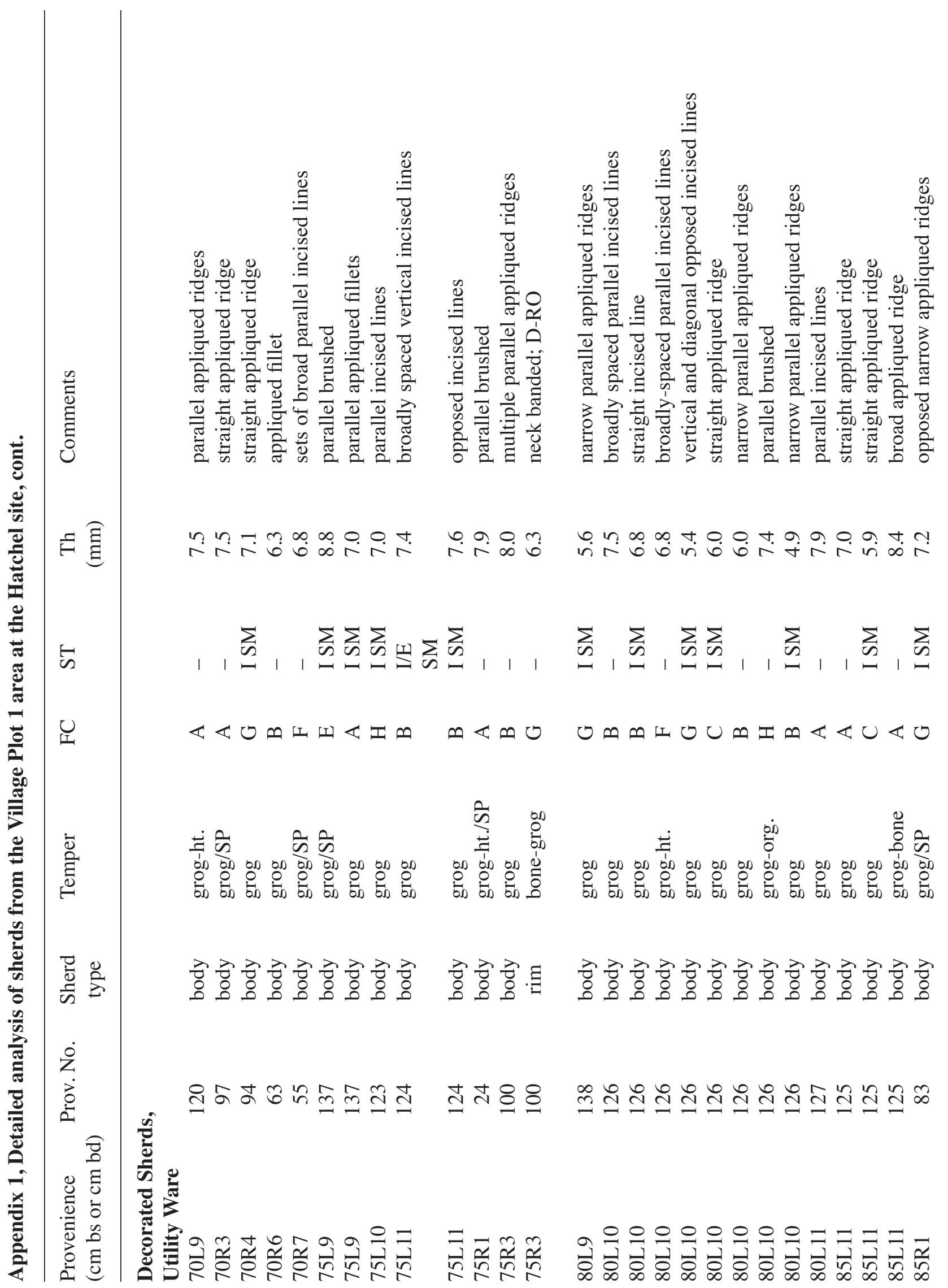




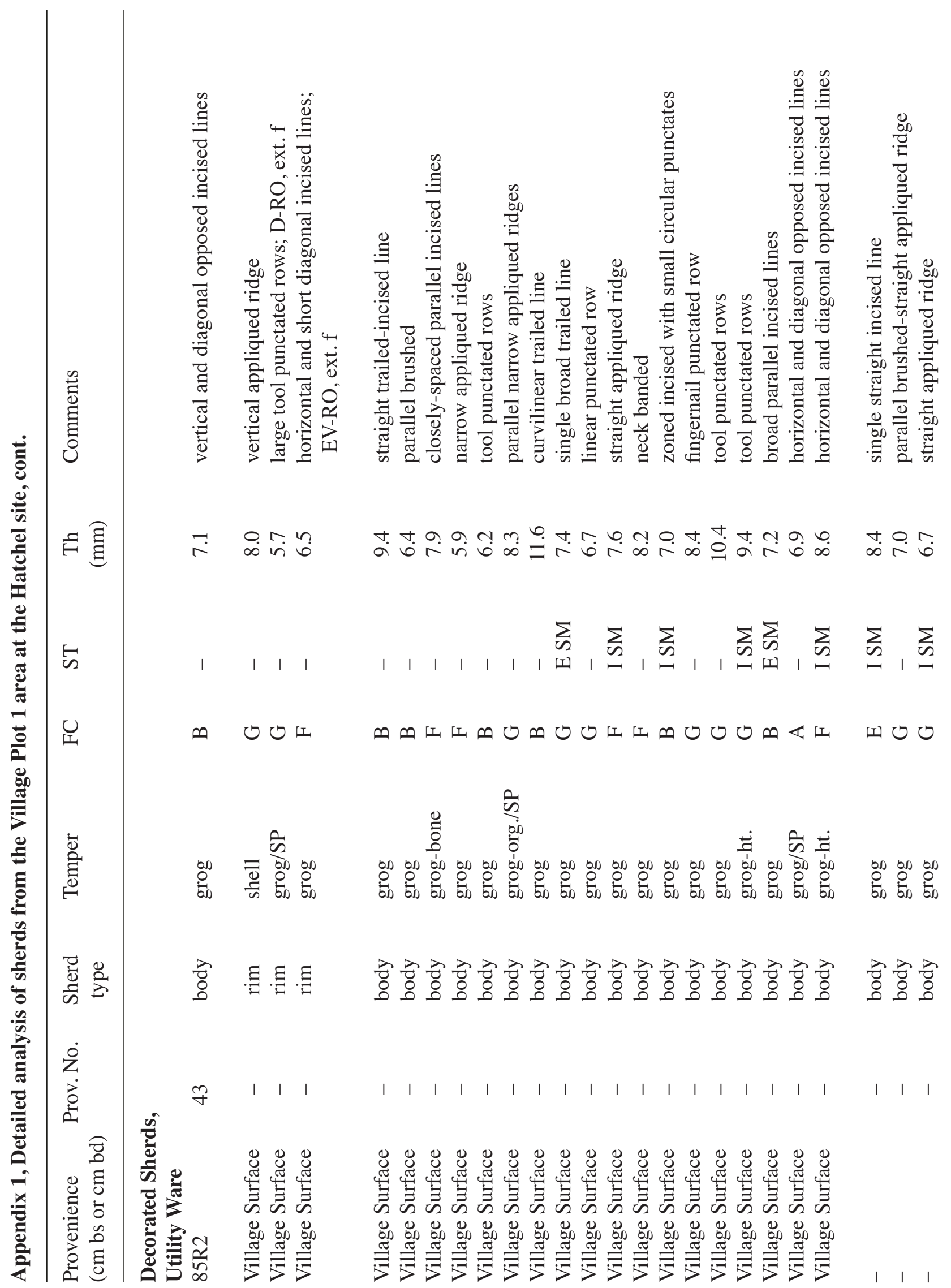




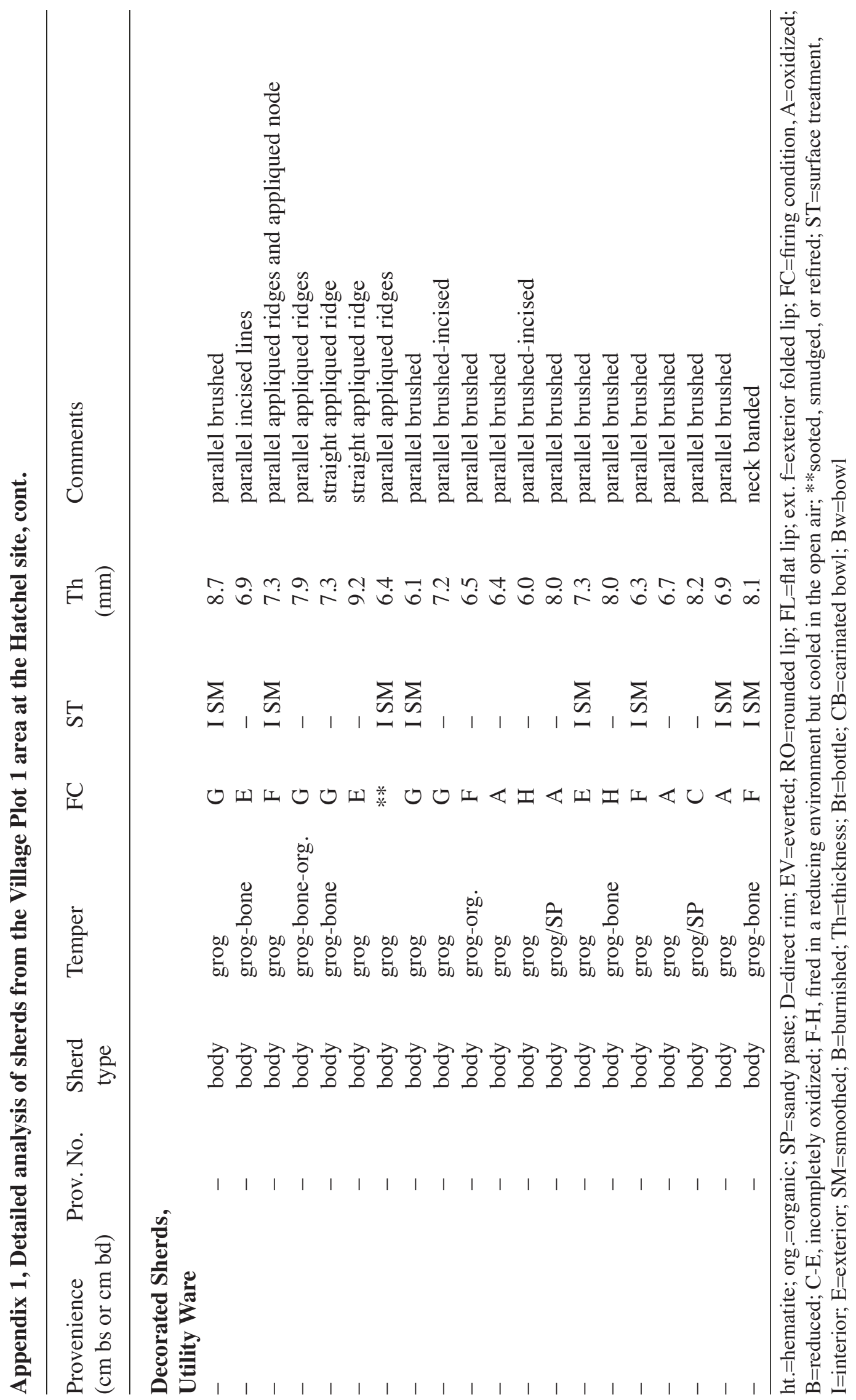

